\title{
Calibration of surface roughness standards
}

Thalmann, R.; Nicolet, A.; Meli, F.; Picotto, G. B.; Matus, M.; Carcedo, L.; Hemming, B.; Ganioglu, O.; De Chiffre, Leonardo; Saraiva, $\mathrm{F}$.

Total number of authors:

19

Published in:

Metrologia

Link to article, DOI:

10.1088/0026-1394/53/1A/04001

Publication date:

2016

Document Version

Publisher's PDF, also known as Version of record

Link back to DTU Orbit

Citation (APA):

Thalmann, R., Nicolet, A., Meli, F., Picotto, G. B., Matus, M., Carcedo, L., Hemming, B., Ganioglu, O., De Chiffre, L., Saraiva, F., Bergstrand, S., Zelenika, S., Tonmueanwai, A., Tsai, C. S., Shihua, W., Kruger, O., de Souza, M. M., Salgado, J. A., \& Ramotowski, Z. (2016). Calibration of surface roughness standards. Metrologia, 53(1A), [04001]. https://doi.org/10.1088/0026-1394/53/1A/04001

\section{General rights}

Copyright and moral rights for the publications made accessible in the public portal are retained by the authors and/or other copyright owners and it is a condition of accessing publications that users recognise and abide by the legal requirements associated with these rights.

- Users may download and print one copy of any publication from the public portal for the purpose of private study or research.

- You may not further distribute the material or use it for any profit-making activity or commercial gain

- You may freely distribute the URL identifying the publication in the public portal 


\title{
Key Comparison EURAMET.L-K8.2013 \\ Calibration of surface roughness standards
}

\author{
EURAMET project \#1245
}

\section{Final report}

Rudolf Thalmann (METAS),

Anaïs Nicolet (METAS), Felix Meli (METAS), Gian Bartolo Picotto (INRIM), Michael Matus (BEV), Laura Carcedo (CEM), Antti Lassila (MIKES), Okhan Ganioglu (UME), Leonardo De Chiffre (DTU-CGM), Fernanda Saraiva (IPQ), Sten Bergstrand (SP), Slobodan Zelenika

(DMDM), Anusorn Tonmueanwai (NIMT), Chin-Lung Tsai (CMS/ITRI), Wang Shihua (NMC/A*STAR), Oelof Kruger (NMISA), Marcos Motta de Souza (INMETRO), José Antonio Salgado (LNE), Zbigniew Ramotowski (GUM) 


\section{Contents}

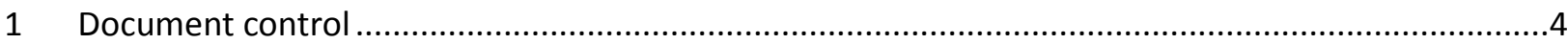

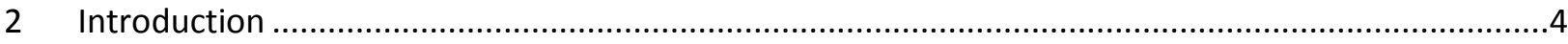

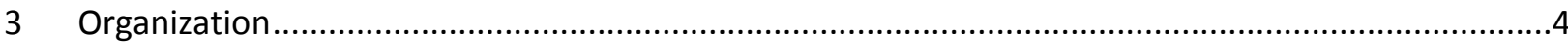

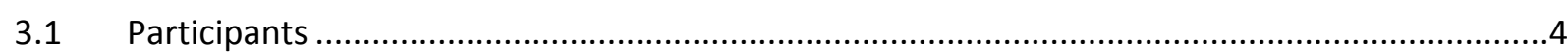

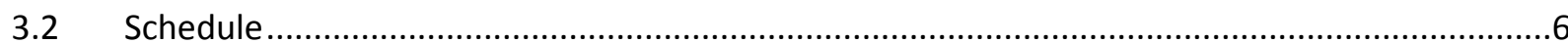

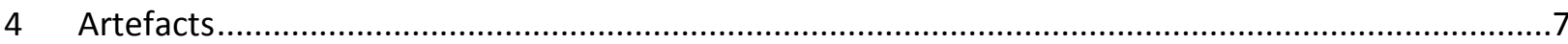

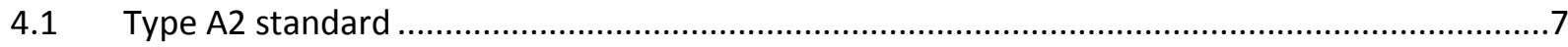

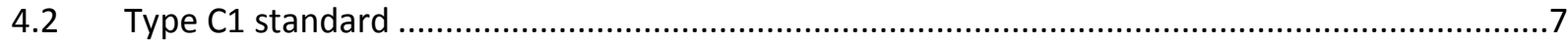

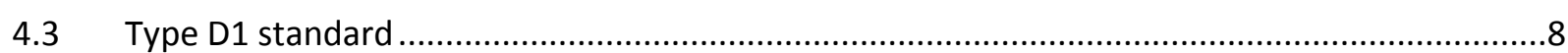

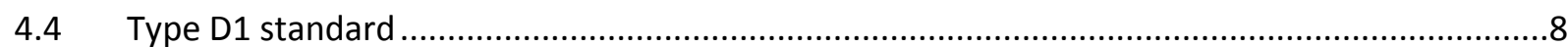

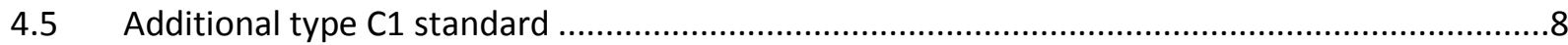

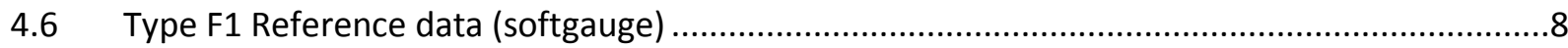

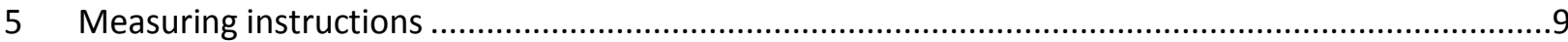

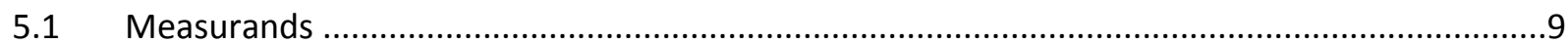

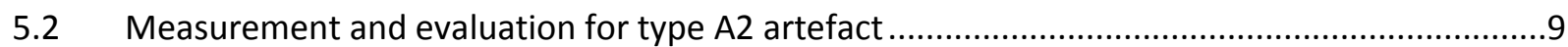

5.3 Measurement conditions for type C1 and D1 artefacts .................................................... 10

5.4 Evaluation of type F1 reference data.................................................................................... 10

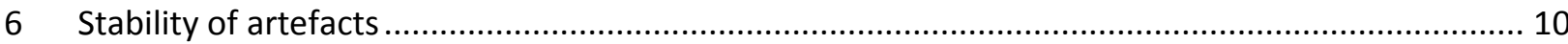

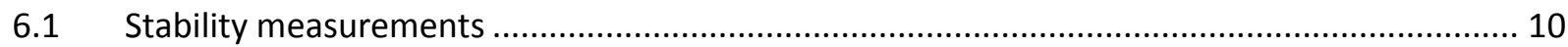

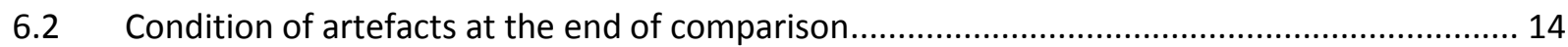

6.3 Description of the damages observed at the end of the comparison .................................... 16

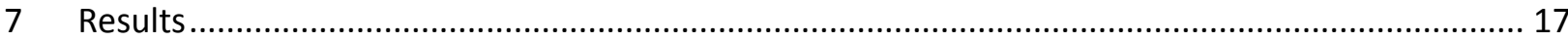

7.1 Results and standard uncertainties as reported by participants ............................................ 17

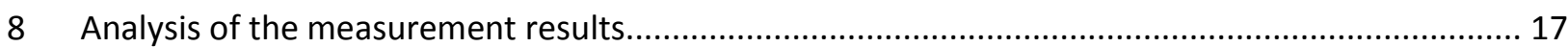

8.1 Calculation of the KCRV and of the Degrees of Equivalence ................................................ 17

8.2 Results, Reference values and Degrees of Equivalence ........................................................ 19

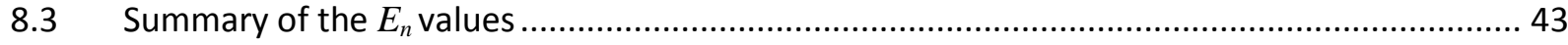

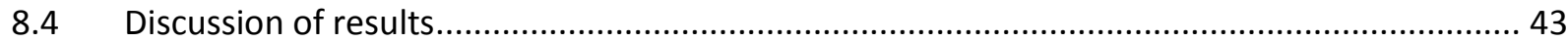

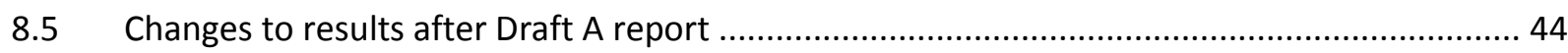

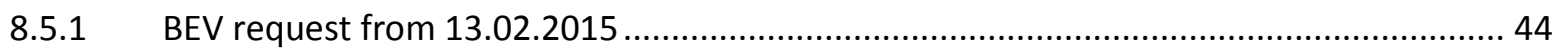

8.5.2 NMISA comment from 06.03.2015 and report from 22.04.2015 .................................. 44

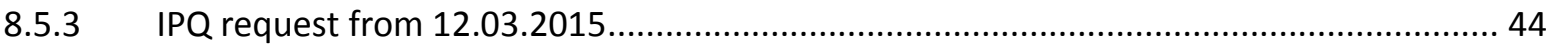

8.6 Comments received after Draft B.1 report ............................................................................. 45

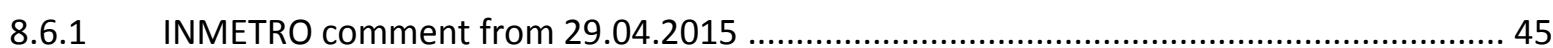

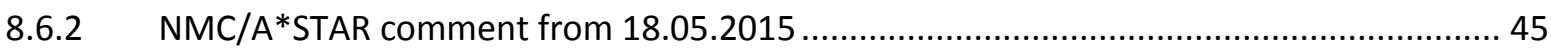

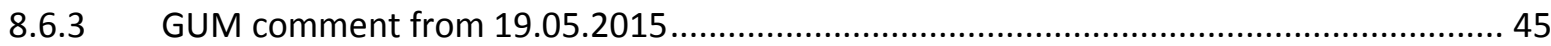


8.7 En-values with results revised after draft A and draft B.1 report....................................46

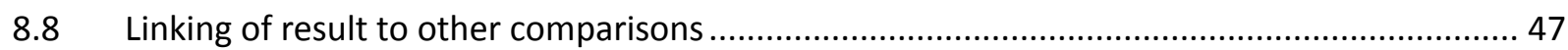

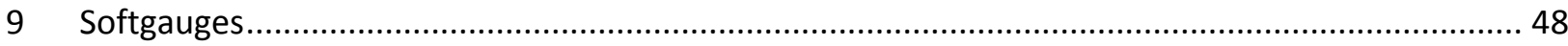

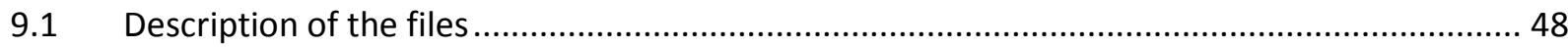

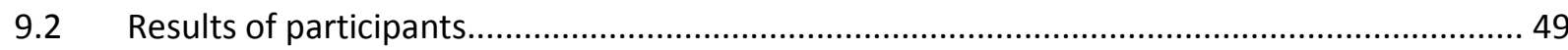

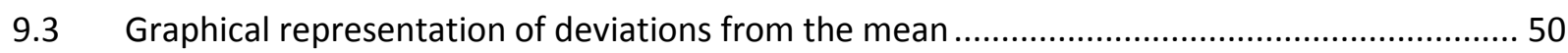

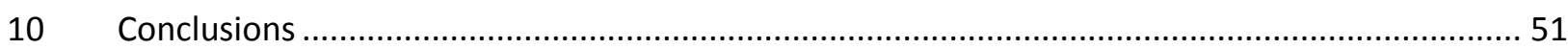

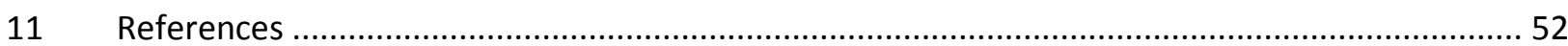

12 Appendix: Equipment of the participating laboratories ................................................. 53

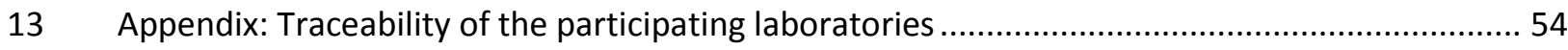

14 Appendix: CMCs as declared by the participating laboratories in the CIPM MRA .....................55 


\section{Document control}

Version Draft B.1 Version Draft B.2 Version Draft B.3 Version Draft B.4 Final report
Issued on April 2015.

Issued on June 2015, comments participants taken in to account. Issued on August 2015, minor typos and comment in section 8.7. Issued on September 2015, minor editorial change. Issued on October 2015, taking into account comments from CCL WG-MRA reviewers

\section{Introduction}

The metrological equivalence of national measurement standards and of calibration certificates issued by national metrology institutes is established by a set of key and supplementary comparisons chosen and organized by the Consultative Committees of the CIPM or by the regional metrology organizations in collaboration with the Consultative Committees.

At its meeting in October 2012, the EURAMET Technical Committee for length, EURAMET-TCL, decided upon a key comparison on the calibration of surface roughness standards, named EURAMET.L-K8.2013, with METAS as the pilot laboratory. The comparison was registered in January 2013, measurements were made between February 2013 and February 2015. The protocol followed the instructions of the preceding comparison EURAMET.L-K8 [1] as closely as possible.

\section{Organization}

\subsection{Participants}

Table 1. List of participant laboratories and their contacts.

\begin{tabular}{|c|c|c|}
\hline $\begin{array}{l}\text { Laboratory } \\
\text { Code }\end{array}$ & Contact person, Laboratory & Phone, Fax, email \\
\hline $\begin{array}{l}\text { METAS } \\
\text { (Pilot) }\end{array}$ & $\begin{array}{l}\text { Ruedi Thalmann } \\
\text { Federal Institute of Metrology METAS } \\
\text { Lindenweg } 50 \\
\text { CH-3003-Bern-Wabern } \\
\text { Switzerland }\end{array}$ & $\begin{array}{l}\text { Tel. +41583870385 } \\
\text { Fax }+41583870210 \\
\text { e-mail: rudolf.thalmann@metas.ch }\end{array}$ \\
\hline LNE & $\begin{array}{l}\text { José Antonio Salgado } \\
\text { LNE } \\
\text { Laboratoire national de métrologie et d'essais } \\
\text { 1, rue Gaston Boissier } \\
\text { F-75015 Paris } \\
\text { France }\end{array}$ & $\begin{array}{l}\text { Tel. +33140433777 } \\
\text { Fax+33140433737 } \\
\text { e-mail: Jose.Salgado@Ine.fr }\end{array}$ \\
\hline INRIM & $\begin{array}{l}\text { Gian Bartolo Picotto } \\
\text { Istituto Nazionale di Ricerca Metrologica } \\
\text { Strade delle Cacce, 91, } \\
10135 \text { Torino } \\
\text { Italy }\end{array}$ & $\begin{array}{l}\text { Tel : } 39113919969 \text { or } 973 \\
\text { Fax : } 39113919959 \\
\text { e-mail : g.picotto@inrim.it }\end{array}$ \\
\hline BEV & $\begin{array}{l}\text { Michael Matus } \\
\text { Bundesamt für Eich- und Vermessungswesen BEV } \\
\text { Arltgasse } 35 \\
\text { A-1160 Wien } \\
\text { Austria }\end{array}$ & $\begin{array}{l}\text { Tel. +43 } 1211106540 \\
\text { Fax +43 } 1211106000 \\
\text { e-mail: michael.matus@bev.gv.at }\end{array}$ \\
\hline CEM & $\begin{array}{l}\text { Laura Carcedo } \\
\text { Head of the Surface Quality Laboratory } \\
\text { Length Area } \\
\text { CENTRO ESPAÑOL DE METROLOGÍA }\end{array}$ & $\begin{array}{l}\text { Tel. +34918074716 } \\
\text { Fax +34918074807 } \\
\text { e-mail: Icarcedo@cem.minetur.es }\end{array}$ \\
\hline
\end{tabular}




\begin{tabular}{|c|c|c|}
\hline & $\begin{array}{l}\text { Alfar, } 2 \text { - Tres Cantos } \\
28760 \text { Madrid } \\
\text { Spain }\end{array}$ & \\
\hline MIKES & $\begin{array}{l}\text { Antti Lassila } \\
\text { Mittatekniikan keskus - Centre for Metrology and } \\
\text { Accreditation (MIKES) } \\
\text { P.O. box } 9 \text { (Tekniikantie 1) } \\
\text { FIN-02151 Espoo } \\
\text { Finland }\end{array}$ & \begin{tabular}{|l} 
Tel: +358 295054413 \\
GSM: +358 407678584 \\
Fax: +358 295054499 \\
e-mail: Antti.Lassila@mikes.fi
\end{tabular} \\
\hline UME & $\begin{array}{l}\text { Okhan Ganioglu } \\
\text { TÜBiTAK UME } \\
\text { Ulusal Metroloji Enstitüsü } \\
\text { TÜBiTAK Gebze Yerleşkesi } \\
\text { Barış Mah. Dr.Zeki Acar Cad. No:1 } \\
41470 \text { Gebze / Kocaeli } \\
\text { Turkey }\end{array}$ & $\begin{array}{l}\text { Tel : +9026267950 } 00 \text { (ext. 5300) } \\
\text { Fax : +90 } 2626795001 \\
\text { e-mail : okhan.ganioglu@tubitak.gov.tr }\end{array}$ \\
\hline DTU-CGM & $\begin{array}{l}\text { Leonardo De Chiffre } \\
\text { DTU Mekanik - CGM } \\
\text { Produktionstorvet 427A } \\
\text { DK-2800 Kgs. Lyngby } \\
\text { Denmark }\end{array}$ & $\begin{array}{l}\text { Tel. +4545254760 } \\
\text { Fax +4545930190 } \\
\text { e-mail: Idch@mek.dtu.dk }\end{array}$ \\
\hline GUM & $\begin{array}{l}\text { Zbigniew Ramotowski } \\
\text { Central Office of Measures (GUM) } \\
\text { Director of Length \& Angle Department } \\
\text { ul. Elektoralna } 2 \\
00-139 \text { Warszawa } \\
\text { Poland }\end{array}$ & $\begin{array}{l}\text { Tel.: +48225819543 } \\
\text { Fax: +4822620 83 78 } \\
\text { e-mail: length@gum.gov.pl }\end{array}$ \\
\hline $\mathrm{IPQ}$ & $\begin{array}{l}\text { Fernanda Saraiva } \\
\text { Instituto Portugês da Qualidade } \\
\text { Rua António Gião, } 2 \\
\text { 2829-513 CAPARICA } \\
\text { Portugal }\end{array}$ & $\begin{array}{l}\text { Tel: + } 351212948160 \\
\text { Fax: + } 351212848188 \\
\text { e-mail: fsaraiva@ipq.pt }\end{array}$ \\
\hline SP & $\begin{array}{l}\text { Sten Bergstrand } \\
\text { SP Technical Research Institute of Sweden } \\
\text { Measurement Technology } \\
\text { Box } 857 \\
\text { SE-501 } 15 \text { Borås } \\
\text { Sweden }\end{array}$ & $\begin{array}{l}\text { Tel. +461051657 73 } \\
\text { Fax +46105165620 } \\
\text { e-mail: sten.bergstrand@sp.se }\end{array}$ \\
\hline DMDM & $\begin{array}{l}\text { Slobodan Zelenika } \\
\text { Directorate of Measures and Precious Metals } \\
\text { Mike Alasa } 14 \\
11000 \text { Belgrade } \\
\text { Serbia }\end{array}$ & $\begin{array}{l}\text { Tel : +381112024421 } \\
\text { Fax : +381112181668 } \\
\text { e-mail: zelenika@dmdm.rs }\end{array}$ \\
\hline NIMT & $\begin{array}{l}\text { Anusorn Tonmueanwai } \\
\text { Dimensional Metrology Department } \\
\text { National Institute of Metrology Thailand } \\
3 \text { / 4-5 Moo 3, Klong 5, Klong Luang, } \\
\text { Pathumthani } 12120 \\
\text { Thailand }\end{array}$ & $\begin{array}{l}\text { Tel : +6625775100 ext } 1202 \\
\text { Fax : +662 } 5775088 \\
\text { e-mail: anusorn@nimt.or.th }\end{array}$ \\
\hline CMS/ITRI & $\begin{array}{l}\text { Chin-Lung Tsai ( Walter Tsai ) } \\
\text { CMS/ITRI } \\
\text { Bldg. 16, No. 321, Sec. 2, Kuang Fu Rd. } \\
\text { Hsinchu city 30011 } \\
\text { Taiwan (R.O.C.) }\end{array}$ & $\begin{array}{l}\text { Tel: +88635743764 } \\
\text { Fax: +886 } 35726445 \\
\text { e-mail: Walter_Tsai@itri.org.tw }\end{array}$ \\
\hline $\begin{array}{l}\text { NMC/ } \\
\text { A*STAR }\end{array}$ & $\begin{array}{l}\text { Wang Shihua } \\
\text { NMC/A*STAR }\end{array}$ & $\begin{array}{l}\text { Tel : } 62791941 \\
\text { Fax : } 62791992\end{array}$ \\
\hline
\end{tabular}




\begin{tabular}{|l|l|l|}
\hline & $\begin{array}{l}\text { 1 Science Park Drive } \\
\text { Singapore 118221 } \\
\text { Singapore }\end{array}$ & e-mail: wang_shihua@nmc.a-star.edu.sg \\
\hline NMISA & $\begin{array}{l}\text { Oelof Kruger } \\
\text { Bld 5 CSIR campus } \\
\text { Meiring Naude road, Brumeria } \\
\text { Pretoria } \\
\text { South Africa }\end{array}$ & $\begin{array}{l}\text { Tel : + } 27128414340 \\
\text { Fax }:+27128414458 \\
\text { e-mail: oakruger@nmisa.org }\end{array}$ \\
\hline INMETRO & $\begin{array}{l}\text { Marcos Motta de Souza } \\
\text { Dimensional Metrology Laboratory } \\
\text { INMETRO - National Institute of Metrology } \\
\text { Quality and Technology } \\
\text { Av. N.Sra. das Graças, 50 } \\
\text { Xérem, Duque de Caxias, RJ. } \\
\text { Brazil }\end{array}$ & $\begin{array}{l}\text { Tel. +55 21 2679 9726 } \\
\text { Fax +55 21 2679 9597 }\end{array}$ \\
\hline
\end{tabular}

\subsection{Schedule}

Details of the planned and actual schedules as well as date of receipt of results from the participants are shown in Table 2. The MRA states that the results should be sent within six weeks of completing the measurements.

Table 2. Schedule of the comparison.

\begin{tabular}{|l|l|l|l|l|}
\hline RMO & Laboratory & $\begin{array}{l}\text { Planned date of } \\
\text { measurement }\end{array}$ & $\begin{array}{l}\text { Actual date of } \\
\text { measurement }\end{array}$ & $\begin{array}{l}\text { Results } \\
\text { received }\end{array}$ \\
\hline EURAMET & METAS & Mar 2013 & Feb 2013 & 11.03 .2013 \\
\hline & DTU-CGM & Apr 2013 & Apr 2013 & 14.08 .2013 \\
\hline & MIKES & May 2013 & May 2013 & 21.06 .2013 \\
\hline & IPQ & Jun 2013 & Jun 2013 & 08.08 .2013 \\
\hline & BEV & July 2013 & Jul 2013 & 06.09 .2013 \\
\hline & SP & Aug 2013 & Aug 2013 & 18.10 .2013 \\
\hline & INRIM & Sep 2013 & Sep 2013 & 18.04 .2014 \\
\hline & LNE & Oct 2013 & Oct 2013 & 11.04 .2014 \\
\hline & CEM & Nov 2013 & Nov 2013 & 04.09 .2014 \\
\hline & GUM & Dec 2013 & Dec 2013 & 31.01 .2014 \\
\hline & METAS & Jan 2014 & Jan 2014 \\
(stability check) & 13.01 .2014 \\
\hline & DMDM & Feb 2013 & Feb 2014 & 13.08 .2014 \\
\hline & UME & Mar 2013 & Mar 2014 & 27.05 .2014 \\
\hline APMP & NIMT & Apr 2013 & Apr 2014 & 06.06 .2014 \\
\hline & NMC/A*STAR & May 2014 & May 2014 & 03.10 .2014 \\
\hline & CMS/ITRI & Jun 2014 & Jun 2014 & 17.10 .2014 \\
\hline AFRIMETS & NMISA & Jul 2014 & Dec 2014 & 10.02 .2015 \\
\hline SIM & INMETRO & Aug 2014 & Aug 2014 & 08.12 .2014 \\
\hline EURAMET & METAS & Sep 2014 & $\begin{array}{l}\text { Feb 2015 } \\
\text { (stability check) }\end{array}$ & 10.02 .2015 \\
\hline & & & & \\
\hline
\end{tabular}

The original schedule has been changed in the course of the comparison, mainly due to the requirement, that participants after January 2014 needed an ATA carnet and because NMISA was not ready with their equipment in the time slot originally allocated. There were no major transportation or customs problems, except import/export to and from Brazil, which took much more time. This didn't delay the comparison, since they were scheduled at the end of the circulation. 


\section{Artefacts}

Five standards were circulated: one type A2, two type C1 and two type D1 according to ISO 5436-1 [2]. The standards were from different manufacturers and different materials. A plastic case $(40 \mathrm{~cm} \times 32 \mathrm{~cm}$ $x 17 \mathrm{~cm}$ ) containing 4 wooden boxes with the artefacts and the technical protocol was used for transportation (Figure 1).

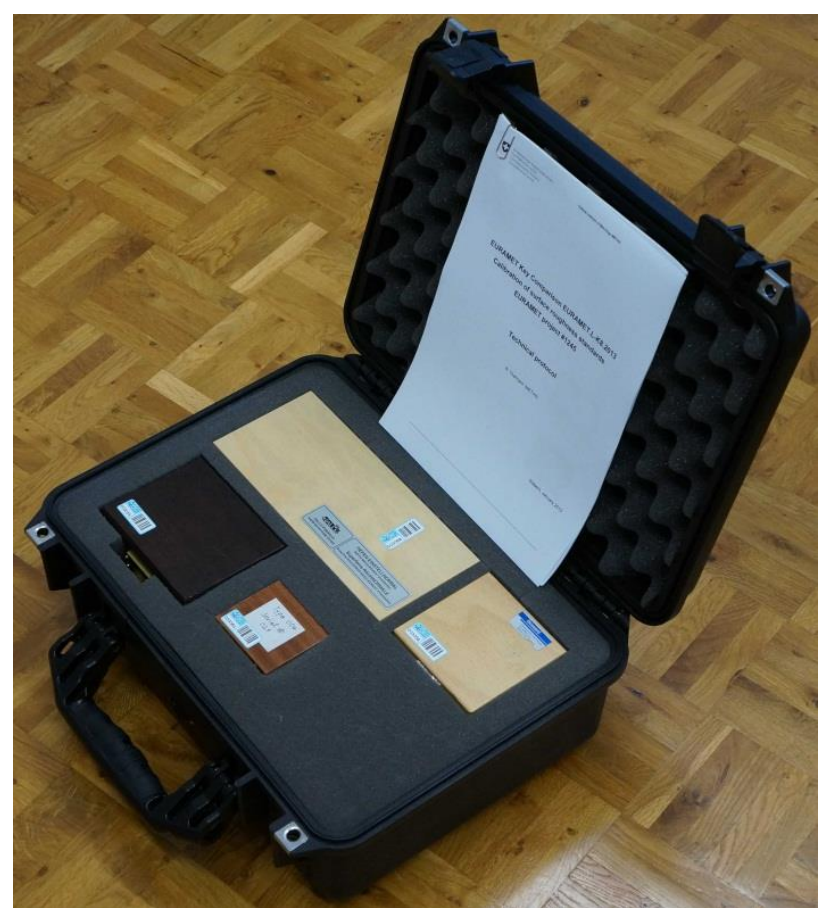

Figure 1. Transporting case.

\subsection{Type A2 standard}

Depth measurement standard, KNT 2060/01, S/N 0589606 Manufacturer: Halle, material: glass

6 grooves with rounded bottoms, nominal values $d 0.33 \mu \mathrm{m}$ to $8.93 \mu \mathrm{m}$

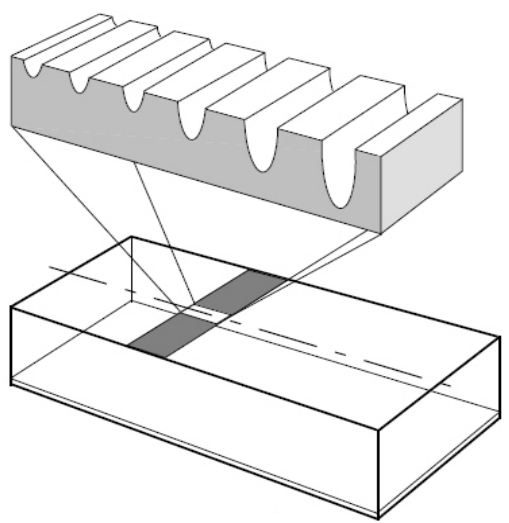

\subsection{Type $\mathrm{C} 1$ standard}

Spacing measurement standard, PGN 10, no 6820605

Manufacturer: Perthen, material: glass

sine wave profile,

nominal values $R a 2.3 \mu \mathrm{m}, R S m 200 \mu \mathrm{m}$

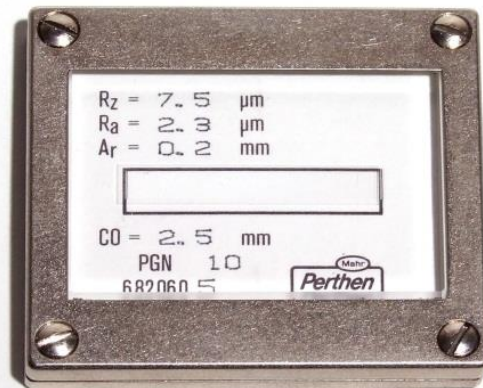




\subsection{Type D1 standard}

Roughness measurement standard, type 004, S/N 021

Manufacturer: Rubert, material: electroformed metal, unidirectional irregular profile, nominal values $R a 0.15 \mu \mathrm{m}$

Measurement area: Between the two marking lines.

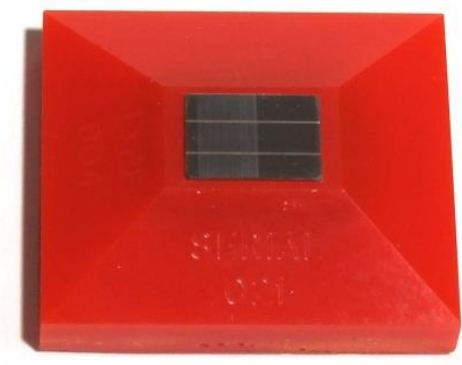

\subsection{Type D1 standard}

Roughness measurement standard, KNT 2070/03, S/N 0986

Manufacturer: Halle, material: hard nickel plate unidirectional irregular profile, nominal values $R a 0.06 \mu \mathrm{m}$

http://www.halle-normale.de/pdf/2011/englisch/06 KNT-4058 Te normale.de/pdf/2011/englisch/15 Ps-KNT-4070 Bl 6-1 GB.pdf

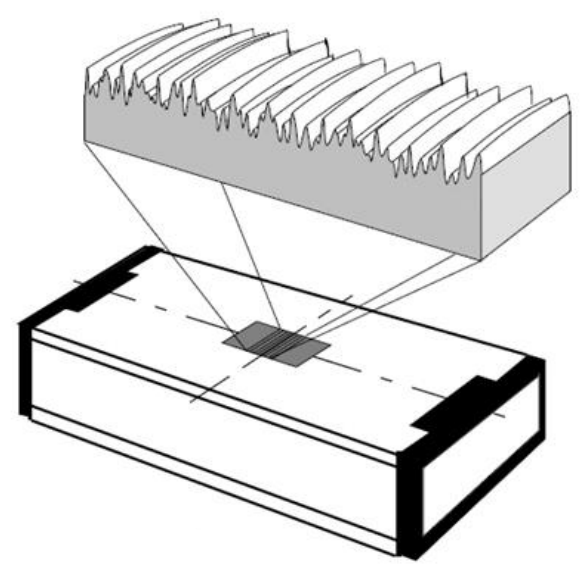

\subsection{Additional type C1 standard}

Spacing measurement standard, NIST SRM 2072, S/N 1015

Manufacturer: NIST, material: steel sine wave profile,

nominal values $R a 1 \mu \mathrm{m}, R S m 100 \mu \mathrm{m}$

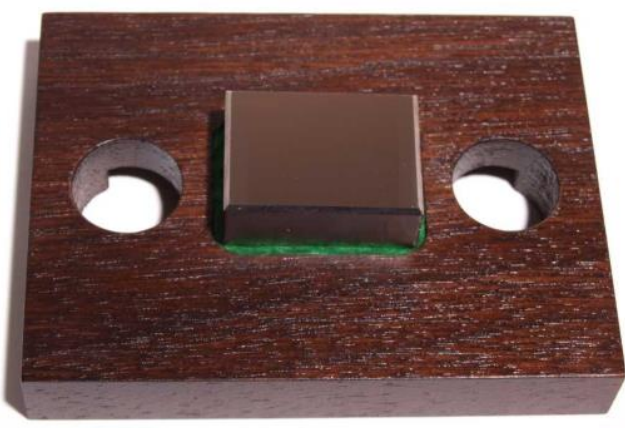

\subsection{Type F1 Reference data (softgauge)}

Two softgauges in 7-bit ASCII character code ( ${ }^{*}$.smd format) according to ISO 5436-2 were included in a memory stick to investigate software algorithms independently of hardware variation:

METAS_Aperiodic.smd: Aperiodic profile METAS_Periodic.smd: Periodic profile

The two data files correspond to primary profiles, i.e. after removal of form but before $\lambda s$ filtering. For laboratories not able to deal with the *.smd format, also files in *.prf format were available. The *.prf format files were kindly transformed by LNE from the *.smd format files. 


\section{Measuring instructions}

\subsection{Measurands}

The following parameters were to be determined:

\begin{tabular}{|l|l|l|}
\hline Artefact & Parameters & $\begin{array}{l}\text { Relevant } \\
\text { standards }\end{array}$ \\
\hline $\begin{array}{l}\text { Type A2 } \\
\text { KNT 2060/01 }\end{array}$ & $d, P t$ & $\begin{array}{l}\text { ISO 5436-1 [2] } \\
\text { ISO 4287 [3] }\end{array}$ \\
\hline $\begin{array}{l}\text { Type C1 } \\
\text { PGN 10 }\end{array}$ & $R a, R q, R z, R t, R S m$ & $\begin{array}{l}\text { ISO 5436-1 } \\
\text { ISO 4287 }\end{array}$ \\
\hline $\begin{array}{l}\text { Type D1 } \\
\text { S/N 021 }\end{array}$ & $R a, R q, R z, R t$ & $\begin{array}{l}\text { ISO 5436-1 } \\
\text { ISO 4287 }\end{array}$ \\
\hline $\begin{array}{l}\text { Type D1 } \\
\text { KNT 2070/03 }\end{array}$ & $R a, R q, R z, R t$ & $\begin{array}{l}\text { ISO 5436-1 } \\
\text { ISO 4287 }\end{array}$ \\
\hline $\begin{array}{l}\text { Type C1 } \\
\text { SRM 2072 }\end{array}$ & $R a, R q, R z, R t, R S m$ & $\begin{array}{l}\text { ISO 5436-1 } \\
\text { ISO 4287 }\end{array}$ \\
\hline Type F1 & $R a, R q, R z, R t, R s k$, & $\begin{array}{l}\text { ISO 5436-2 } \\
\text { ISO 4287 }\end{array}$ \\
\hline
\end{tabular}

For each parameter, its value and the observed standard deviation $\sigma$ had to be reported.

\subsection{Measurement and evaluation for type $\mathrm{A} 2$ artefact}

A least squares mean line representing the upper level is drawn over the groove. A least squares circle is fitted through the centre third of the width of the groove. The depth $d$ is evaluated from the line to the lowest point of the fitted circle (see Figure 2). The portions to be used for the evaluation are those shown at $A, B$ and $C$ in Figure 2. The average of five traces, evenly distributed over the measuring window, together with the standard deviation $\sigma$ were to be reported.

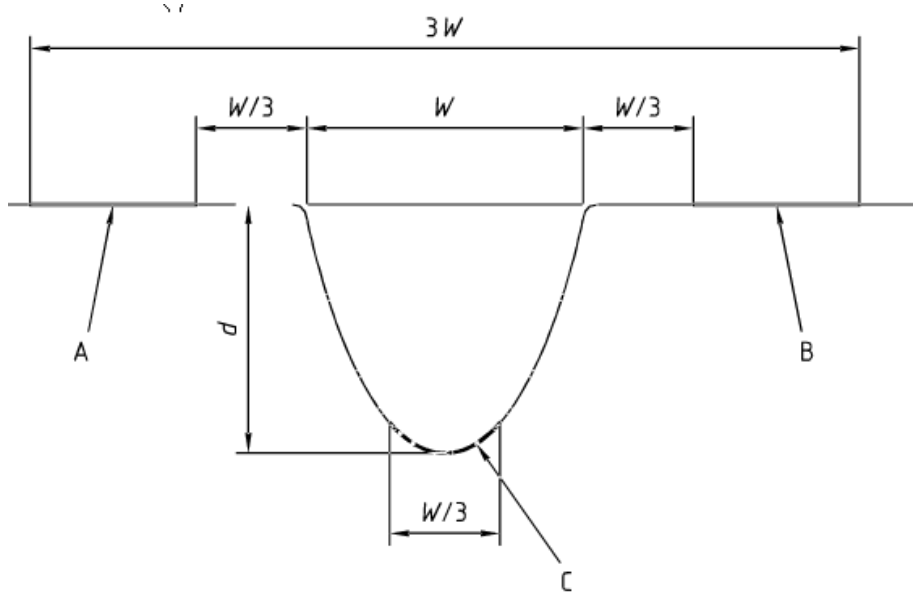

Figure 2. Assessment of the depth measurement standard (ISO 5436-1).

Note, that the laboratories were also asked to determine Pt (see table in 5.1). However, since $d$ is the standardized measurand for type A2 standards according to ISO 5436-1 and all laboratories were able to determine $d$, the $P t$ results are not reported here because they would provide essentially redundant information. They were, however, included in the results spreadsheet distributed to the participants. 


\subsection{Measurement conditions for type C1 and D1 artefacts}

The average of twelve traces, evenly distributed over the measuring window, together with the standard deviation $\sigma$ were to be reported. A Gaussian filter according to ISO 16610-21:2011 had to be applied for evaluating the $R$ parameters.

\begin{tabular}{|l|l|l|l|l|l|l|}
\hline Standard & $\begin{array}{l}\text { Evaluation } \\
\text { length } \\
(\mathrm{mm})\end{array}$ & $\lambda_{\boldsymbol{c}}(\mu \mathrm{m})$ & $\lambda_{\boldsymbol{S}}(\mu \mathrm{m})$ & $\begin{array}{l}\text { Measuring } \\
\text { force }(\mathrm{mN})\end{array}$ & $\begin{array}{l}\text { Sampling } \\
\text { spacing } \\
(\mu \mathrm{m})\end{array}$ & $\begin{array}{l}\text { Tip radius } \\
(\mu \mathrm{m})\end{array}$ \\
\hline $\begin{array}{l}\text { Type C1 } \\
\text { PGN 10 }\end{array}$ & 4.00 & 800 & 2.5 & $<1$ & $\leq 0.5$ & 2 \\
\hline $\begin{array}{l}\text { Type D1 } \\
\text { S/N 021 }\end{array}$ & 4.00 & 800 & 2.5 & $<1$ & $\leq 0.5$ & 2 \\
\hline $\begin{array}{l}\text { Type D1 } \\
\text { KNT 2070/03 }\end{array}$ & 1.25 & 250 & 2.5 & $<1$ & $\leq 0.5$ & 2 \\
\hline $\begin{array}{l}\text { Type C1 } \\
\text { SRM 2072 }\end{array}$ & 4.00 & 800 & 2.5 & $<1$ & $\leq 0.5$ & 2 \\
\hline
\end{tabular}

\subsection{Evaluation of type F1 reference data}

The following evaluation parameters were to be respected:

\begin{tabular}{|l|l|l|l|l|l|}
\hline Standard & File name & $\begin{array}{l}\text { Evaluation } \\
\text { length }(\mathbf{m m})\end{array}$ & $\lambda_{\boldsymbol{c}}(\boldsymbol{\mu \mathrm { m }})$ & $\lambda_{\boldsymbol{s}}(\boldsymbol{\mu \mathrm { m }})$ & Parameters \\
\hline F1 aperiodic & METAS_Aperiodic.smd & 1.25 & 250 & 2.5 & $R a, R q, R z, R t, R s k$ \\
\hline F1 periodic & METAS_Periodic.smd & 4.00 & 800 & 2.5 & $R a, R q, R z, R t, R s k, R S m$ \\
\hline
\end{tabular}

The total profile length is 7 cutoff lengths $\left(7 \lambda_{c}\right)$. The evaluation length $l_{n}$ was the five central sampling length $l_{\mathrm{r}}=\lambda_{\mathrm{c}}$, thus removing one cutoff length on each side in order to avoid end effects.

\section{Stability of artefacts}

\subsection{Stability measurements}

METAS measured the samples in February 2013, in January 2014 and in February 2015, i.e. at the beginning, in the middle and at the end of the comparison. Note that only the first result in February 2013 accounts for the key comparison, the other two were to monitor the stability of the samples. For simplicity, the evaluation of these measurement data was done in the same way as for the participant's results, i.e. the deviation from the weighted mean and the $E_{n}$ values were calculated for each parameter and each standard. 
Table 3 shows the results of the stability measurements carried out by the pilot laboratory, where the "reference value" $x_{\text {ref }}$ is the weighted mean of the three results $x_{i}$. All $E_{n}$ values are smaller than 0.5 , which can be interpreted that there is no significant change within the uncertainty.

Table 3. Results of stability measurements by the pilot laboratory.

\begin{tabular}{|c|c|c|c|c|c|c|}
\hline Parameter & Period & $x_{i} / \mu m$ & $u_{i} / \mu \mathrm{m}$ & $\left(x_{i}-x_{\text {ref }}\right) / \mu \mathrm{m}$ & $U\left(x_{i}-x_{\text {ref }}\right) / \mu \mathrm{m}$ & $\boldsymbol{E}_{n}$ \\
\hline \multicolumn{7}{|c|}{ Type A2, KNT 2060/01, S/N 0589606} \\
\hline \multirow{3}{*}{$\mathrm{R} 1, d$} & Feb 2013 & 0.317 & 0.010 & -0.002 & 0.016 & 0.12 \\
\hline & Jan 2014 & 0.315 & 0.011 & -0.004 & 0.019 & 0.21 \\
\hline & Feb 2015 & 0.324 & 0.010 & 0.005 & 0.016 & 0.32 \\
\hline \multirow{3}{*}{$\mathrm{R} 2, d$} & Feb 2013 & 0.405 & 0.011 & -0.001 & 0.017 & 0.05 \\
\hline & Jan 2014 & 0.407 & 0.011 & 0.001 & 0.017 & 0.07 \\
\hline & Feb 2015 & 0.405 & 0.016 & -0.001 & 0.029 & 0.03 \\
\hline \multirow{3}{*}{$\mathrm{R} 3, d$} & Feb 2013 & 1.343 & 0.011 & 0.001 & 0.019 & 0.06 \\
\hline & Jan 2014 & 1.344 & 0.010 & 0.002 & 0.016 & 0.13 \\
\hline & Feb 2015 & 1.339 & 0.010 & -0.003 & 0.016 & 0.18 \\
\hline \multirow{3}{*}{$\mathrm{R} 4, d$} & Feb 2013 & 2.713 & 0.011 & -0.003 & 0.018 & 0.17 \\
\hline & Jan 2014 & 2.723 & 0.012 & 0.007 & 0.020 & 0.35 \\
\hline & Feb 2015 & 2.713 & 0.011 & -0.003 & 0.018 & 0.17 \\
\hline \multirow{3}{*}{$\mathrm{R} 5, d$} & Feb 2013 & 5.520 & 0.011 & -0.004 & 0.018 & 0.22 \\
\hline & Jan 2014 & 5.533 & 0.012 & 0.009 & 0.020 & 0.45 \\
\hline & Feb 2015 & 5.520 & 0.011 & -0.004 & 0.018 & 0.22 \\
\hline \multirow{3}{*}{$\mathrm{R} 6, d$} & Feb 2013 & 8.915 & 0.014 & 0.002 & 0.022 & 0.09 \\
\hline & Jan 2014 & 8.934 & 0.023 & 0.021 & 0.043 & 0.49 \\
\hline & Feb 2015 & 8.906 & 0.012 & -0.007 & 0.017 & 0.42 \\
\hline \multicolumn{7}{|c|}{ Type C1, PGN 10, no 6820605} \\
\hline \multirow{3}{*}{$\mathrm{Ra}$} & Feb 2013 & 2.372 & 0.018 & 0.000 & 0.029 & 0.01 \\
\hline & Jan 2014 & 2.368 & 0.018 & -0.004 & 0.029 & 0.13 \\
\hline & Feb 2015 & 2.375 & 0.018 & 0.004 & 0.029 & 0.13 \\
\hline \multirow{3}{*}{$\mathrm{Rq}$} & Feb 2013 & 2.660 & 0.020 & 0.002 & 0.032 & 0.05 \\
\hline & Jan 2014 & 2.654 & 0.021 & -0.005 & 0.035 & 0.14 \\
\hline & Feb 2015 & 2.662 & 0.021 & 0.003 & 0.035 & 0.09 \\
\hline \multirow{3}{*}{$\mathrm{Rz}$} & Feb 2013 & 7.705 & 0.063 & 0.021 & 0.102 & 0.21 \\
\hline & Jan 2014 & 7.663 & 0.063 & -0.020 & 0.102 & 0.20 \\
\hline & Feb 2015 & 7.682 & 0.067 & -0.001 & 0.112 & 0.01 \\
\hline \multirow{3}{*}{ Rt } & Feb 2013 & 7.764 & 0.065 & 0.012 & 0.105 & 0.12 \\
\hline & Jan 2014 & 7.737 & 0.066 & -0.015 & 0.108 & 0.14 \\
\hline & Feb 2015 & 7.754 & 0.068 & 0.002 & 0.112 & 0.02 \\
\hline \multirow{3}{*}{$\mathrm{RSm}$} & Feb 2013 & 199.930 & 0.067 & -0.055 & 0.109 & 0.50 \\
\hline & Jan 2014 & 199.990 & 0.067 & 0.005 & 0.109 & 0.05 \\
\hline & Feb 2015 & 200.033 & 0.067 & 0.049 & 0.109 & 0.45 \\
\hline
\end{tabular}




\begin{tabular}{|c|c|c|c|c|c|c|}
\hline Parameter & Period & $x_{i} / \mu m$ & $u_{\mathrm{i}} / \mu \mathrm{m}$ & $\left(x_{i}-x_{\mathrm{ret}}\right) / \mu \mathrm{m}$ & $U\left(x_{i}-x_{\text {ref }}\right) / \mu \mathrm{m}$ & $E_{n}$ \\
\hline \multicolumn{7}{|c|}{ Type D1, S/N 021} \\
\hline \multirow{3}{*}{$\mathrm{Ra}$} & Feb 2013 & 0.126 & 0.003 & 0.002 & 0.005 & 0.43 \\
\hline & Jan 2014 & 0.124 & 0.003 & 0.000 & 0.005 & 0.03 \\
\hline & Feb 2015 & 0.122 & 0.003 & -0.002 & 0.005 & 0.40 \\
\hline \multirow{3}{*}{$\mathrm{Rq}$} & Feb 2013 & 0.159 & 0.003 & 0.002 & 0.005 & 0.31 \\
\hline & Jan 2014 & 0.157 & 0.003 & 0.000 & 0.005 & 0.04 \\
\hline & Feb 2015 & 0.155 & 0.003 & -0.002 & 0.005 & 0.36 \\
\hline \multirow{3}{*}{$\mathrm{Rz}$} & Feb 2013 & 1.056 & 0.039 & 0.009 & 0.064 & 0.14 \\
\hline & Jan 2014 & 1.060 & 0.038 & 0.013 & 0.062 & 0.20 \\
\hline & Feb 2015 & 1.027 & 0.037 & -0.020 & 0.060 & 0.33 \\
\hline \multirow{3}{*}{ Rt } & Feb 2013 & 1.220 & 0.050 & 0.030 & 0.085 & 0.36 \\
\hline & Jan 2014 & 1.184 & 0.043 & -0.005 & 0.067 & 0.08 \\
\hline & Feb 2015 & 1.170 & 0.046 & -0.020 & 0.075 & 0.26 \\
\hline \multicolumn{7}{|c|}{ Type D1, KNT 2070/03, S/N 0986} \\
\hline \multirow{3}{*}{$\mathrm{Ra}$} & Feb 2013 & 0.060 & 0.002 & 0.000 & 0.004 & 0.03 \\
\hline & Jan 2014 & 0.060 & 0.002 & 0.000 & 0.004 & 0.03 \\
\hline & Feb 2015 & 0.060 & 0.002 & 0.000 & 0.004 & 0.00 \\
\hline \multirow{3}{*}{$\mathrm{Rq}$} & Feb 2013 & 0.075 & 0.002 & 0.000 & 0.004 & 0.01 \\
\hline & Jan 2014 & 0.075 & 0.002 & 0.000 & 0.004 & 0.02 \\
\hline & Feb 2015 & 0.075 & 0.002 & 0.000 & 0.004 & 0.01 \\
\hline \multirow{3}{*}{$R z$} & Feb 2013 & 0.326 & 0.021 & 0.000 & 0.034 & 0.00 \\
\hline & Jan 2014 & 0.324 & 0.021 & -0.002 & 0.034 & 0.06 \\
\hline & Feb 2015 & 0.328 & 0.021 & 0.002 & 0.034 & 0.06 \\
\hline \multirow{3}{*}{ Rt } & Feb 2013 & 0.442 & 0.023 & -0.001 & 0.038 & 0.04 \\
\hline & Jan 2014 & 0.444 & 0.023 & 0.001 & 0.037 & 0.02 \\
\hline & Feb 2015 & 0.444 & 0.023 & 0.001 & 0.037 & 0.02 \\
\hline \multicolumn{7}{|c|}{ Type C1, NIST SRM 2072, S/N 1015} \\
\hline \multirow{3}{*}{$\mathrm{Ra}$} & Feb 2013 & 1.010 & 0.010 & -0.001 & 0.017 & 0.03 \\
\hline & Jan 2014 & 1.012 & 0.010 & 0.002 & 0.016 & 0.11 \\
\hline & Feb 2015 & 1.009 & 0.010 & -0.001 & 0.016 & 0.08 \\
\hline \multirow{3}{*}{$\mathrm{Rq}$} & Feb 2013 & 1.120 & 0.011 & -0.001 & 0.018 & 0.06 \\
\hline & Jan 2014 & 1.124 & 0.011 & 0.003 & 0.017 & 0.15 \\
\hline & Feb 2015 & 1.120 & 0.011 & -0.002 & 0.017 & 0.09 \\
\hline \multirow{3}{*}{$\mathrm{Rz}$} & Feb 2013 & 3.350 & 0.090 & -0.040 & 0.147 & 0.27 \\
\hline & Jan 2014 & 3.418 & 0.089 & 0.028 & 0.144 & 0.20 \\
\hline & Feb 2015 & 3.400 & 0.090 & 0.011 & 0.148 & 0.07 \\
\hline \multirow{3}{*}{ Rt } & Feb 2013 & 3.370 & 0.090 & -0.061 & 0.140 & 0.44 \\
\hline & Jan 2014 & 3.448 & 0.090 & 0.017 & 0.139 & 0.12 \\
\hline & Feb 2015 & 3.518 & 0.126 & 0.087 & 0.226 & 0.38 \\
\hline \multirow{3}{*}{$\mathrm{RSm}$} & Feb 2013 & 101.658 & 0.063 & 0.044 & 0.097 & 0.45 \\
\hline & Jan 2014 & 101.600 & 0.060 & -0.014 & 0.090 & 0.16 \\
\hline & Feb 2015 & 101.540 & 0.101 & -0.074 & 0.186 & 0.40 \\
\hline
\end{tabular}


For some of the parameters, the stability results are also represented graphically in Figure 3.
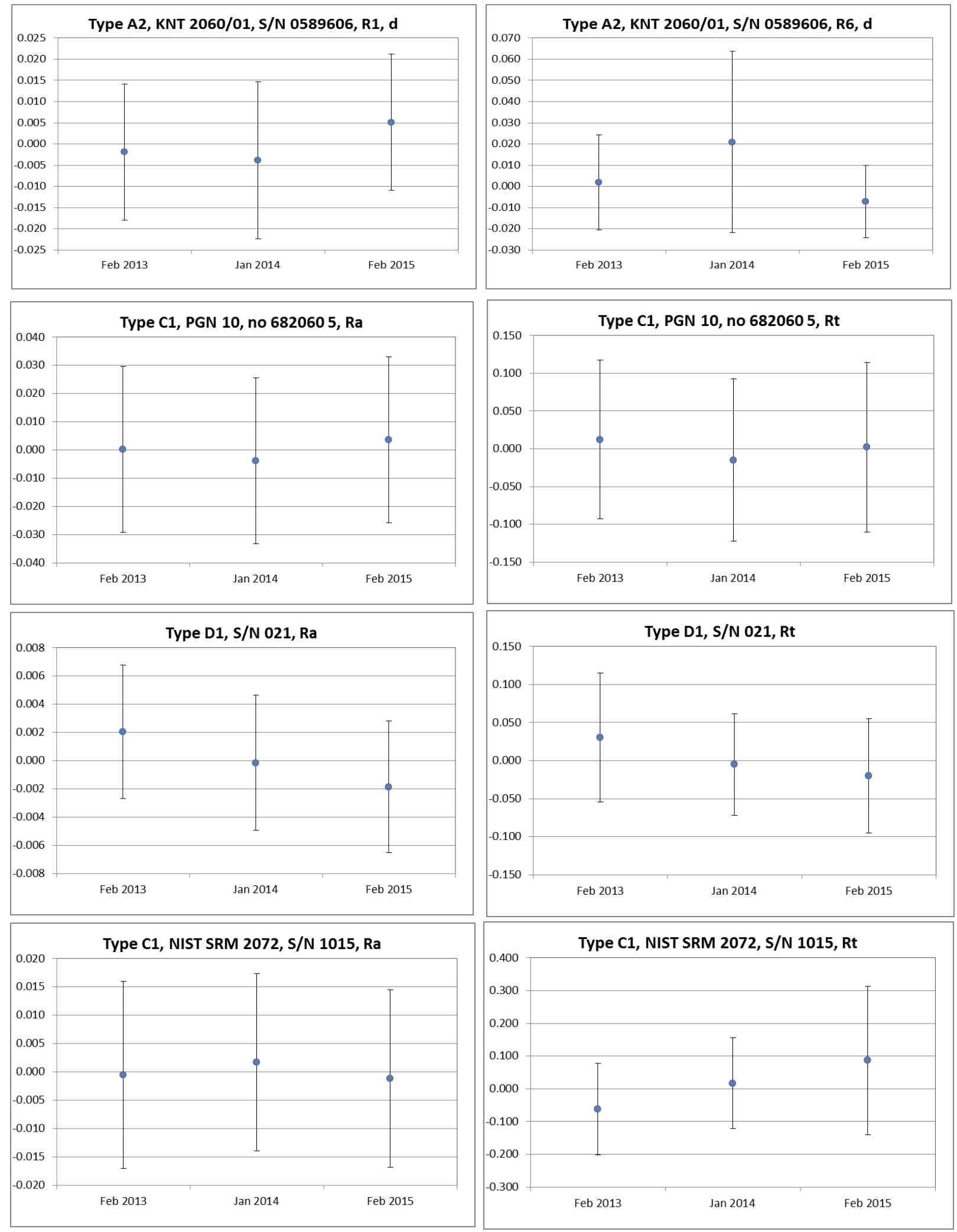

Figure 3. Stability measurements for selected standards and parameters (uncertainty bars for $k=2$ ). 


\subsection{Condition of artefacts at the end of comparison}

Several defects and damages on the standards were reported by the participants, already at an early stage of the comparison. The pilot did not try to identify the date and place, where the damages occurred. However, since the participants were free to choose the exact location of the measured profiles on the artefacts, there was always the possibility to choose a place more or less free of defects. In case a measurement was influenced by a surface defect, this accounts for the standard deviation and is therefore part of the measurement uncertainty. In Figure 4 to Figure 8 , the status of the standards is documented as observed by the pilot at the end of the comparison.

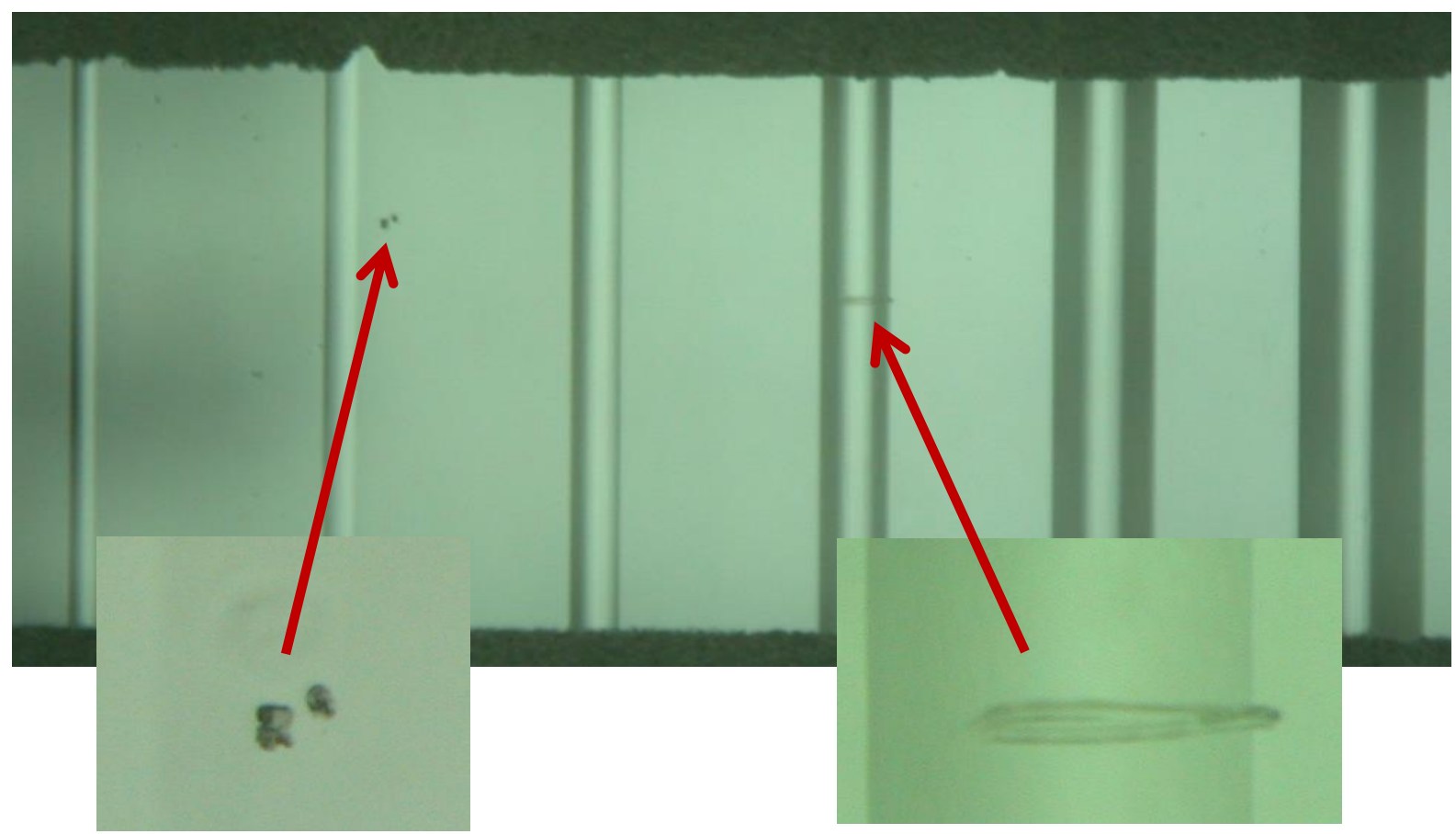

Figure 4. Defects on the standard Halle A2 KNT 2060/01.

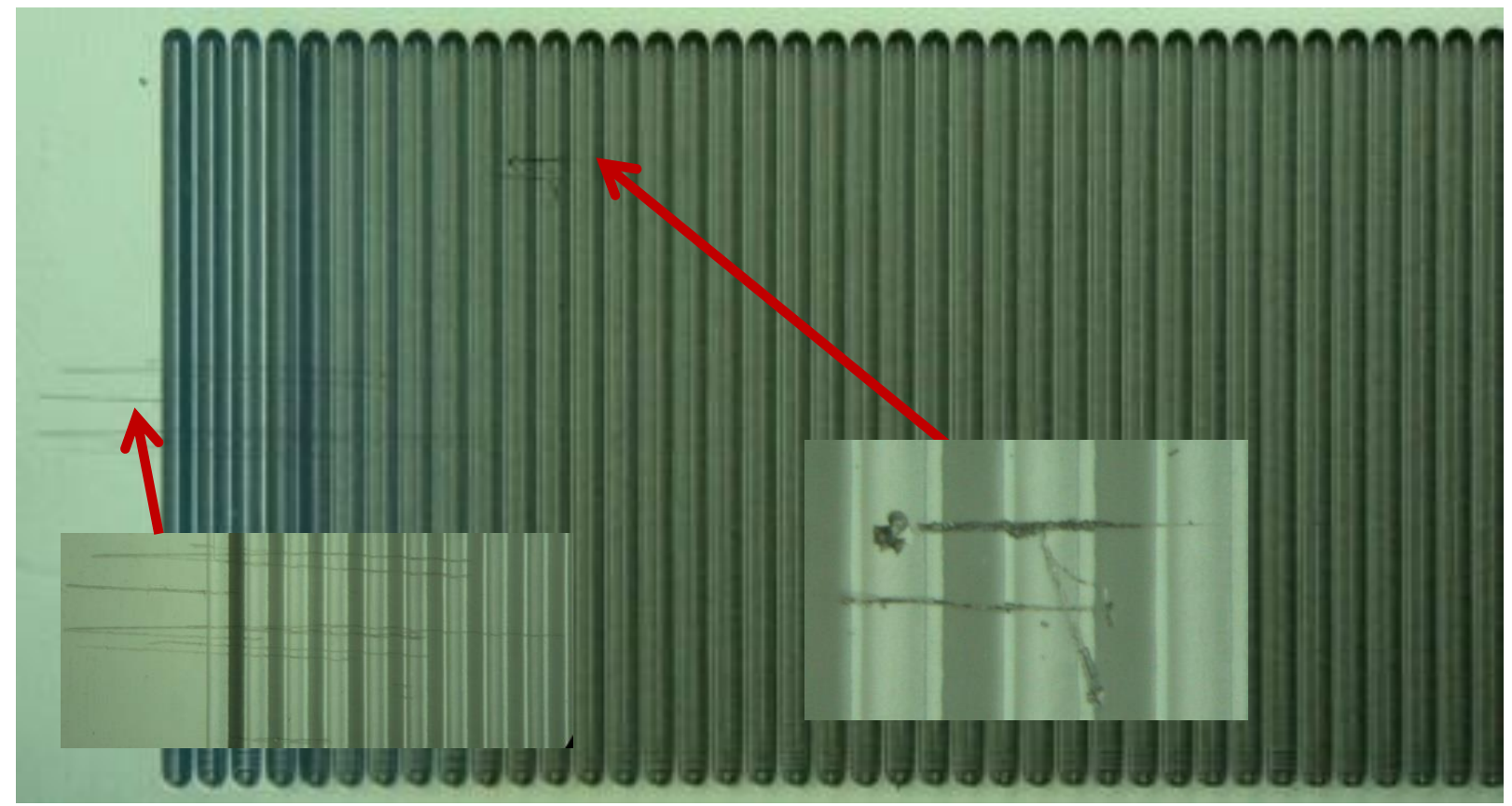

Figure 5. Defects on the standard Perthen C1 PGN 10. 


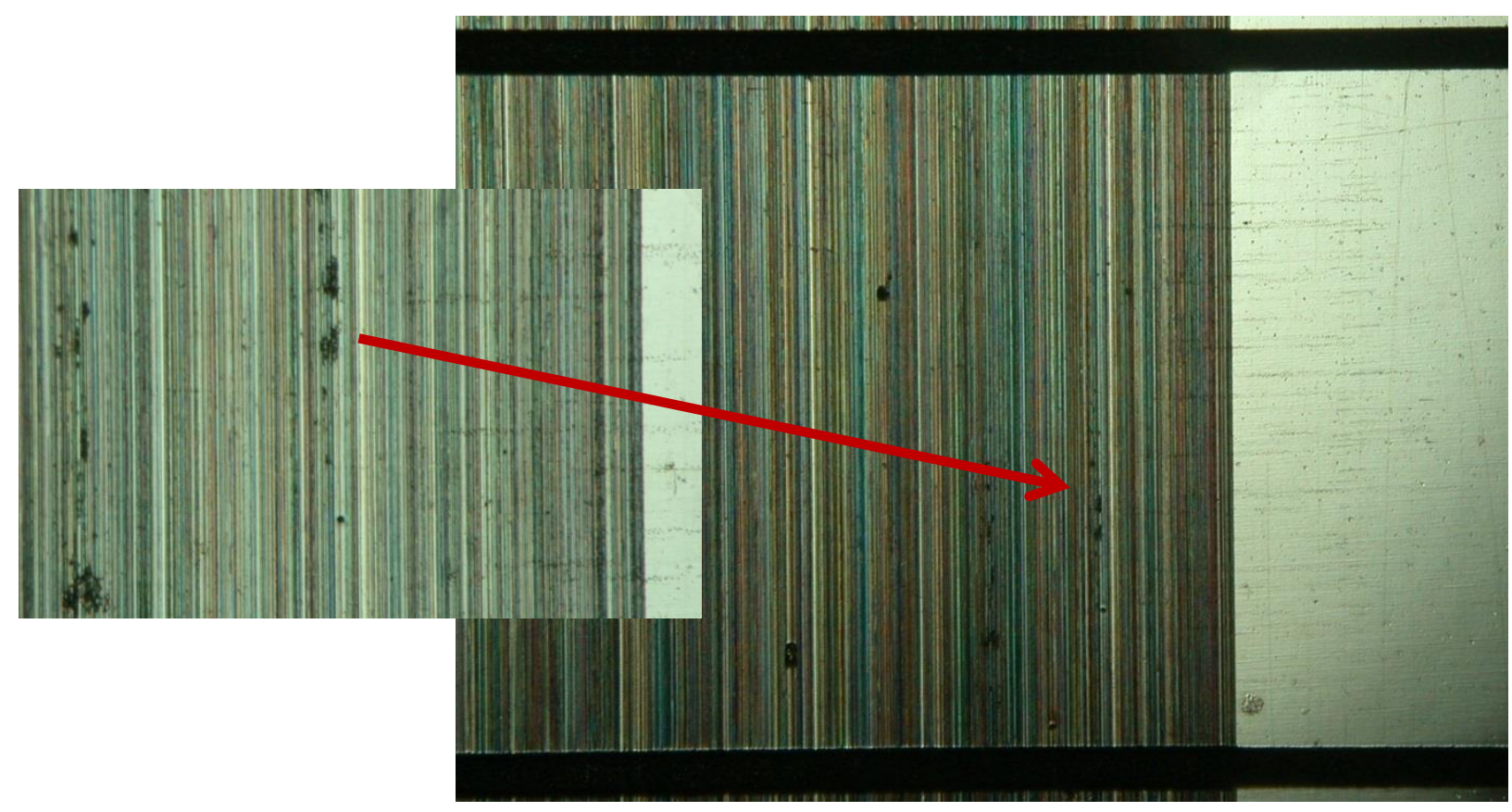

Figure 6. Defects on the standard Rubert D1 SN021.

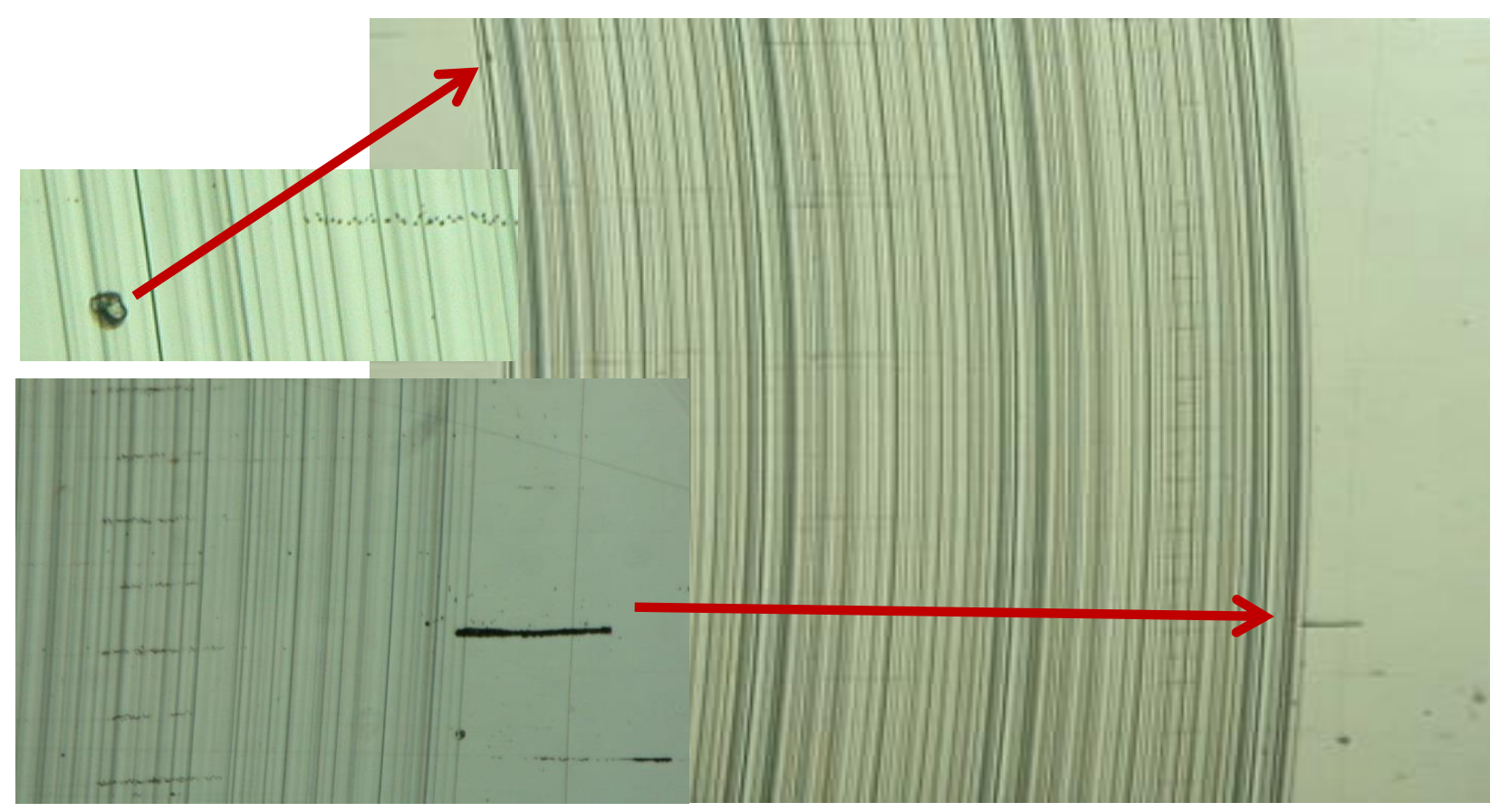

Figure 7. Defects on the standard Halle D1 KNT2070/03. 

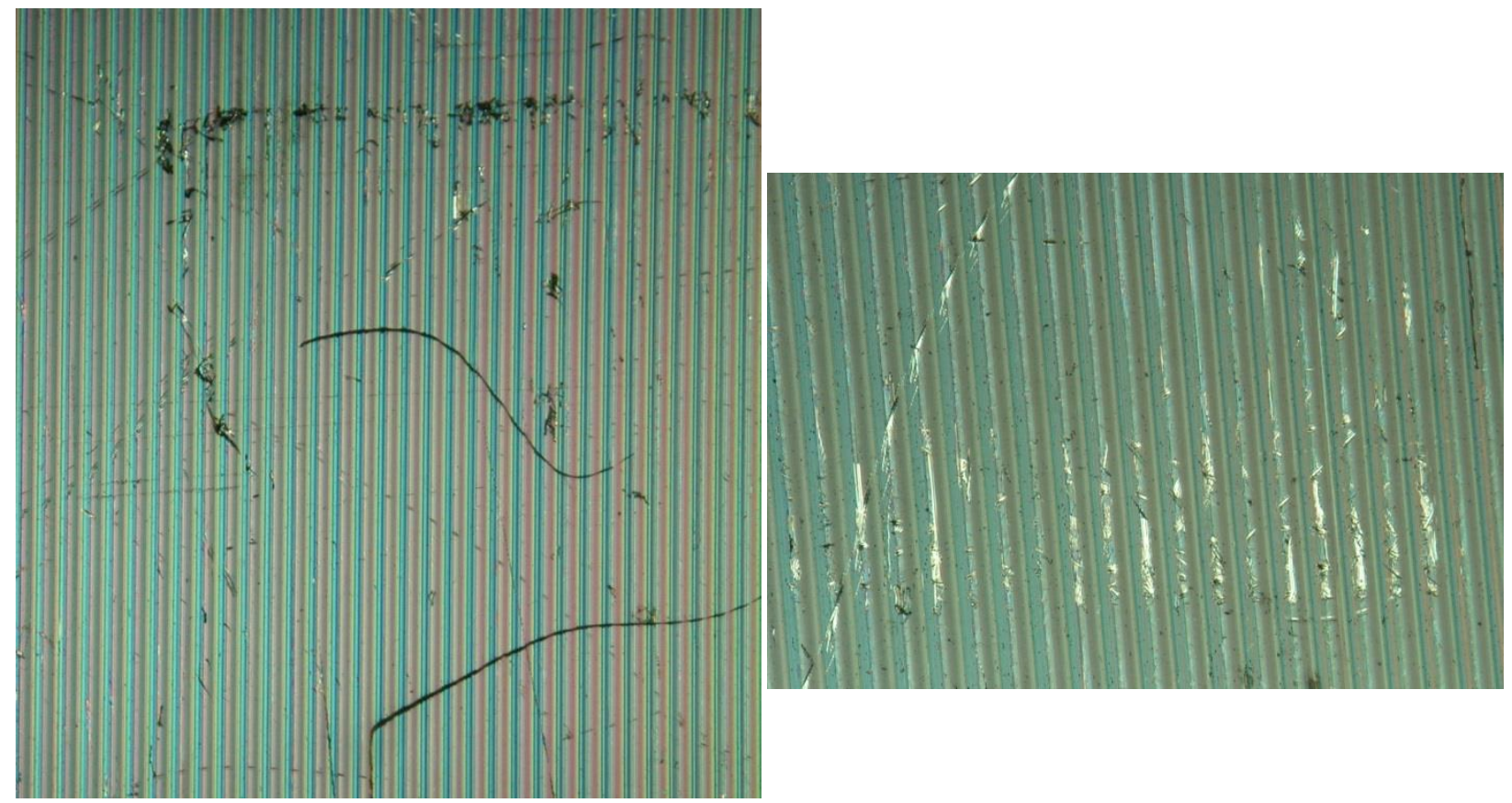

Figure 8. Two defects on the standard NIST C1 SRM 2072.

\subsection{Description of the damages observed at the end of the comparison}

Halle A2 KNT 2060/01

- Scratch on groove R4 (due to a stylus?)

\section{Perthen C1 PGN 10}

- Stylus scratches left in the middle

- Damage left above

\section{Rubert D1 SN021}

- Several stylus scratches

- 3 black spots

- dirty grooves

Halle D1 KNT2070/03

- Stylus scratches all over the surface

- Deep scratch on right side

- Round damage left above

NIST C1 SRM 2072

- Numerous damages and scratches all over the surface.

Note: The pilot did not photographically document the status of the surfaces at the beginning of the comparison. Some minor defects might have been present before the circulation of the standards. 


\section{Results}

\subsection{Results and standard uncertainties as reported by participants}

The results had to be reported by the participants on Word forms in tables such as Table 4. These were all copied in an Excel spreadsheet EURAMET.L-K8.2013-evaluation.xlsx, which served as Draft A report of this comparison. The spread sheet allows for the evaluation of the reference values according to section 8.1 of this report, for the determination of the largest consistent subset and the degrees of equivalence. The results as they were reported by the participants are shown in section 8.2.

Table 4. Format of how the results had to be reported by the participants.

\begin{tabular}{||c|c|c|c|c||}
\hline Parameter & Value $(\mu \mathrm{m})$ & $\sigma(\mu \mathrm{m})$ & $u_{c}(\mathrm{~nm})$ & $v_{\text {eff }}$ \\
\hline$R a$ & & & & \\
\hline$R q$ & & & & \\
\hline$R z$ & & & & \\
\hline$R t$ & & & & \\
\hline$R S m$ & & & & \\
\hline
\end{tabular}

$\sigma: \quad$ standard deviation

$u_{c}:$ standard uncertainty

$v_{\text {eff: }}$ number of effective degrees of freedom (if estimated)

\section{Analysis of the measurement results}

\subsection{Calculation of the KCRV and of the Degrees of Equivalence}

The Key Comparison Reference Values KCRV were calculated for each measurand using the weighted mean. To each result $x_{i}$ a normalised weight $w_{i}$ was attributed, given by:

$$
w_{i}=C \cdot \frac{1}{\left[u\left(x_{i}\right)\right]^{2}}
$$

where the normalising factor, $C$, is given by:

$$
C=\frac{1}{\sum_{i=1}^{I}\left(\frac{1}{u\left(x_{i}\right)}\right)^{2}}
$$

The weighted mean $\bar{x}_{w}$ is given by:

$$
\bar{x}_{w}=\sum_{i=1}^{I} w_{i} \cdot x_{i}
$$

and the uncertainty of the weighted mean is calculated by:

$$
u\left(\bar{x}_{w}\right)=\sqrt{\frac{1}{\sum_{i=1}^{I}\left(\frac{1}{u\left(x_{i}\right)}\right)^{2}}}=\sqrt{C} .
$$


After deriving the weighted mean and its associated standard uncertainty, the deviation of each laboratory's result from the weighted mean is determined simply as $x_{i}-\bar{x}_{w}$. The uncertainty of this deviation is calculated as a combination of the uncertainties of the result, $u\left(x_{i}\right)$, and the uncertainty of the weighted mean $u\left(\bar{x}_{w}\right)$. The uncertainty of the deviation from the weighted mean is given by

$$
u\left(x_{i}-\bar{x}_{w}\right)=\sqrt{\left[u\left(x_{i}\right)\right]^{2}-\left[u\left(\bar{x}_{w}\right)\right]^{2}} .
$$

For the determination of the key comparison reference value KCRV, statistical consistency of the results contributing to the KCRV is required. A check for statistical consistency of the results with their associated uncertainties can be made by the so-called Birge ratio $R_{B}$ which compares the observed spread of the results with the spread expected from the individual reported uncertainties.

The application of least squares algorithms and the $\chi^{2}$-test leads to the Birge ratio

$$
R_{B}=\frac{u_{e x t}\left(\bar{x}_{w}\right)}{u\left(\bar{x}_{w}\right)}
$$

where $u_{\text {ext }}\left(\bar{x}_{w}\right)$ is the external standard deviation

$$
u_{\text {ext }}\left(\bar{x}_{w}\right)=\sqrt{\frac{1}{(I-1)} \cdot \frac{\sum_{i=1}^{I} w_{i}\left(x_{i}-\bar{x}_{w}\right)^{2}}{\sum_{i=1}^{I} w_{i}}} .
$$

The Birge ratio has an expectation value of $R_{B}=1$, when considering standard uncertainties. For a coverage factor of $k=2$, the expectation value is increased and the data in a comparison are consistent provided that

$$
R_{B}<\sqrt{1+\sqrt{8 /(I-1)}}
$$

where $I$ is the number of laboratories.

For each laboratory's result the $E_{n}$ value is calculated, where $E_{n}$ is defined as the ratio of the deviation from the weighted mean, divided by the expanded uncertainty of this deviation:

$$
E_{n}=\frac{\left|x_{i}-\bar{x}_{w}\right|}{\sqrt{\left[U\left(x_{i}\right)\right]^{2}-\left[U\left(\bar{x}_{w}\right)\right]^{2}}} .
$$

If statistical consistency according to equation (8) is not given, the result with the largest $E_{n}$ is identified and excluded from the reference value and $R_{B}$ is calculated again. This process of excluding the result with the largest $E_{n}$ from contributing to the weighted mean is iterated until statistical consistency is reached.

Because inconsistent results are no longer correlated with the weighted mean, when calculating their $E_{n}$ value a positive sign is used in equation (5) and consequently in the denominator of equation (9):

$$
E_{n}=\frac{\left|x_{i}-\bar{x}_{w}\right|}{\sqrt{\left[U\left(x_{i}\right)\right]^{2}+\left[U\left(\bar{x}_{w}\right)\right]^{2}}} \text { for results excluded from the KCRV. }
$$




\subsection{Results, Reference values and Degrees of Equivalence}

In the following, an extract of the Excel table EURAMET.L-K8.2013-evaluation.xIsx is given for each standard and each measurand. Laboratories starting with the largest $E_{n}$ values were excluded (highlighted) until consistency according to the Birge ratio criterion was reached. $E_{n}$ values larger than 1 are highlighted. Tables show final values of $x_{\mathrm{i}}$ and $E_{n}$ for consistent Birge ratio $R_{\mathrm{B}}$. All graphs show the deviations $\left(x_{\mathrm{i}}-x_{\mathrm{w}}\right)$ from the weighted mean key comparison reference value in $\mu \mathrm{m}$ with uncertainties expanded with $k=2$.

\begin{tabular}{|c|c|c|c|c|c|c|c|c|c|c|}
\hline \multirow[b]{2}{*}{ select gauge } & \multirow[b]{2}{*}{1} & & & & \multirow{2}{*}{\multicolumn{2}{|c|}{$\begin{array}{l}\text { use } 1 \text { or } 0 \text { to } \\
\text { in- or exclude }\end{array}$}} & \multirow{2}{*}{$\begin{array}{c}\text { choose: } \\
k=2\end{array}$} & & \multirow[b]{3}{*}{ En } & \multirow[b]{3}{*}{$w_{i}$} \\
\hline & & \multicolumn{3}{|c|}{ Type A2, KNT 2060/01, S/N 0589606, R1, d } & & & & & & \\
\hline Institute & $x_{\mathrm{i}} / \mu \mathrm{m}$ & $\sigma_{\mathrm{i}} / \mu \mathrm{m}$ & $u_{i} / \mu \mathrm{m}$ & $v_{\text {eff }}$ & on/off & {$\left[\left(x_{i}-x_{\mathrm{w}}\right) / \mu \mathrm{m}\right.$} & $k$ & $U\left(x_{i}-x_{\text {ref }}\right) / \mu \mathrm{m}$ & & \\
\hline METAS & 0.317 & 0.003 & 0.010 & 118 & 1 & 0.000 & 2.00 & 0.020 & 0.01 & 0.01 \\
\hline DTU-CGM & 0.320 & 0.005 & 0.014 & 10000 & 1 & 0.003 & 2.00 & 0.028 & 0.11 & 0.01 \\
\hline MIKES & 0.313 & 0.004 & 0.008 & 9 & 1 & -0.003 & 2.00 & 0.015 & 0.22 & 0.02 \\
\hline IPQ & 0.310 & 0.001 & 0.030 & 108 & 1 & -0.007 & 2.00 & 0.060 & 0.11 & 0.00 \\
\hline BEV & 0.327 & 0.003 & 0.003 & 10000 & 1 & 0.010 & 2.00 & 0.006 & 1.84 & 0.14 \\
\hline SP & 0.312 & 0.003 & 0.006 & 162 & 1 & -0.005 & 2.00 & 0.012 & 0.41 & 0.04 \\
\hline INRIM & 0.315 & 0.000 & 0.002 & 47 & 1 & -0.002 & 2.00 & 0.003 & 0.55 & 0.32 \\
\hline LNE & 0.319 & 0.010 & 0.008 & 35 & 1 & 0.002 & 2.00 & 0.016 & 0.14 & 0.02 \\
\hline CEM & 0.315 & 0.003 & 0.003 & 10000 & 1 & -0.002 & 2.00 & 0.005 & 0.41 & 0.18 \\
\hline GUM & 0.324 & 0.004 & 0.015 & 15 & 1 & 0.007 & 2.00 & 0.030 & 0.24 & 0.01 \\
\hline DMDM & 0.325 & 0.005 & 0.008 & 10000 & 1 & 0.008 & 2.00 & 0.016 & 0.50 & 0.02 \\
\hline UME & 0.318 & 0.003 & 0.006 & 278 & 1 & 0.001 & 2.00 & 0.013 & 0.10 & 0.03 \\
\hline NIMT & 0.312 & 0.003 & 0.008 & 5060 & 1 & -0.005 & 2.00 & 0.016 & 0.30 & 0.02 \\
\hline NMC/A*STAR & 0.316 & 0.004 & 0.010 & 10000 & 1 & -0.001 & 2.00 & 0.020 & 0.05 & 0.01 \\
\hline CMS/ITRI & 0.314 & 0.003 & 0.003 & 199 & 1 & -0.003 & 2.00 & 0.005 & 0.61 & 0.16 \\
\hline NMISA & 0.270 & 0.005 & 0.011 & 10000 & 0 & -0.047 & 2.00 & 0.022 & 2.19 & 0.00 \\
\hline INMETRO & 0.321 & 0.003 & 0.011 & 10000 & 1 & 0.004 & 2.00 & 0.021 & 0.18 & 0.01 \\
\hline & $x_{\mathrm{w}}$ & & $u\left(x_{w}\right)$ & $v_{\text {eff }}$ & $N-1$ & & $\boldsymbol{k}_{\text {ref }}$ & & & \\
\hline Reference value & 0.317 & & 0.001 & 416 & 15 & & 2.00 & & & \\
\hline$C$ & $1.28 E-06$ & & & & & & & & & \\
\hline & & & & & & Consisten & & & & \\
\hline & & & & & & $u_{\text {ext }}$ & 0.001 & & & \\
\hline & & & & & & $R_{\mathrm{B}}$ & 1.062 & Birge ok & & \\
\hline & & & & & & Limit & 1.315 & & & \\
\hline
\end{tabular}

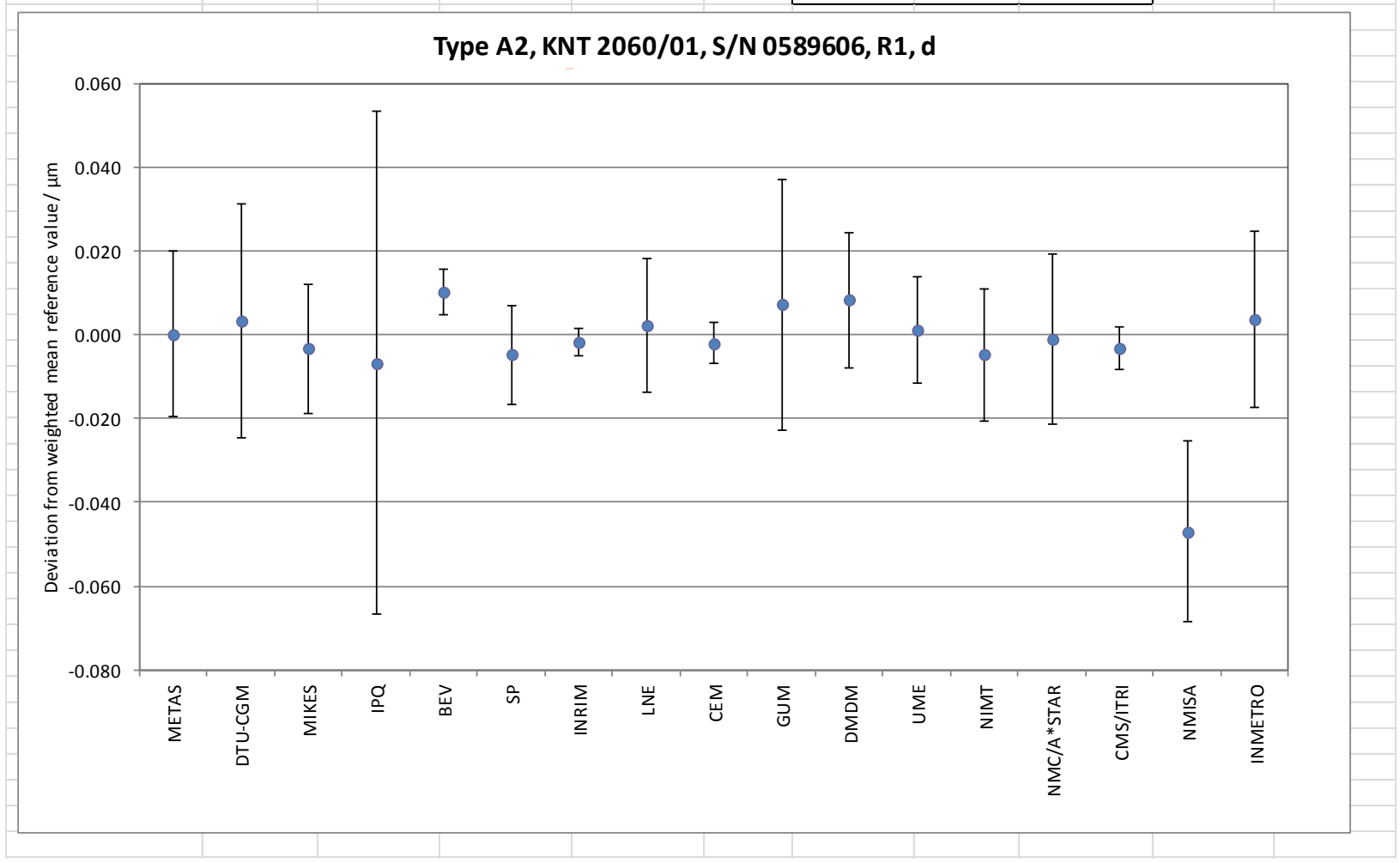




\begin{tabular}{|c|c|c|c|c|c|c|c|c|c|c|}
\hline \multirow[b]{2}{*}{ select gauge } & \multirow[b]{2}{*}{2} & & & & \multirow{2}{*}{\multicolumn{2}{|c|}{$\begin{array}{l}\text { use } 1 \text { or } 0 \text { to } \\
\text { in- or exclude }\end{array}$}} & \multirow{2}{*}{$\begin{array}{c}\text { choose: } \\
k=2\end{array}$} & & \multirow[b]{3}{*}{$E \mathrm{n}$} & \multirow[b]{3}{*}{$w_{i}$} \\
\hline & & \multicolumn{3}{|c|}{ Type A2, KNT 2060/01, S/N 0589606, R2, d } & & & & & & \\
\hline Institute & $x_{\mathrm{i}} / \mu \mathrm{m}$ & $\sigma_{i} / \mu \mathrm{m}$ & $u_{\mathrm{i}} / \mu \mathrm{m}$ & $v_{\text {eff }}$ & on/off & $\left(x_{i}-x_{\mathrm{w}}\right) / \mu \mathrm{m}$ & $k$ & $U\left(x_{i}-x_{\text {ref }}\right) / \mu \mathrm{m}$ & & \\
\hline METAS & 0.405 & 0.005 & 0.011 & 120 & 1 & 0.006 & 2.00 & 0.022 & 0.26 & 0.01 \\
\hline DTU-CGM & 0.405 & 0.005 & 0.014 & 10000 & 1 & 0.006 & 2.00 & 0.028 & 0.20 & 0.01 \\
\hline MIKES & 0.402 & 0.004 & 0.008 & 9 & 1 & 0.002 & 2.00 & 0.015 & 0.16 & 0.03 \\
\hline IPQ & 0.390 & 0.003 & 0.031 & 110 & 1 & -0.009 & 2.00 & 0.062 & 0.15 & 0.00 \\
\hline BEV & 0.405 & 0.004 & 0.003 & 10000 & 1 & 0.006 & 2.00 & 0.005 & 1.04 & 0.20 \\
\hline $\mathrm{SP}$ & 0.398 & 0.002 & 0.006 & 258 & 1 & -0.001 & 2.00 & 0.012 & 0.12 & 0.05 \\
\hline INRIM & 0.399 & 0.006 & 0.005 & 25 & 1 & 0.000 & 2.00 & 0.010 & 0.04 & 0.07 \\
\hline LNE & 0.397 & 0.011 & 0.008 & 41 & 1 & -0.002 & 2.00 & 0.016 & 0.15 & 0.03 \\
\hline CEM & 0.398 & 0.002 & 0.003 & 10000 & 1 & -0.002 & 2.00 & 0.005 & 0.42 & 0.25 \\
\hline GUM & 0.405 & 0.003 & 0.015 & 15 & 1 & 0.006 & 2.00 & 0.030 & 0.19 & 0.01 \\
\hline DMDM & 0.406 & 0.005 & 0.009 & 10000 & 1 & 0.007 & 2.00 & 0.017 & 0.39 & 0.02 \\
\hline UME & 0.402 & 0.003 & 0.006 & 289 & 1 & 0.003 & 2.00 & 0.013 & 0.21 & 0.04 \\
\hline NIMT & 0.396 & 0.009 & 0.009 & 2201 & 1 & -0.003 & 2.00 & 0.017 & 0.20 & 0.02 \\
\hline NMC/A*STAR & 0.402 & 0.005 & 0.010 & 10000 & 1 & 0.002 & 2.00 & 0.020 & 0.11 & 0.02 \\
\hline CMS/ITRI & 0.397 & 0.004 & 0.003 & 214 & 1 & -0.003 & 2.00 & 0.005 & 0.55 & 0.21 \\
\hline NMISA & 0.371 & 0.006 & 0.013 & 10000 & 1 & -0.029 & 2.00 & 0.025 & 1.13 & 0.01 \\
\hline INMETRO & 0.400 & 0.002 & 0.011 & 10000 & 1 & 0.000 & 2.00 & 0.021 & 0.02 & 0.02 \\
\hline & $x_{\mathrm{w}}$ & & $u\left(x_{\mathrm{w}}\right)$ & $v_{\text {eff }}$ & $N-1$ & & $\boldsymbol{k}_{\text {ref }}$ & & & \\
\hline Reference value & 0.399 & & 0.001 & 1828 & 16 & & 2.00 & & & \\
\hline$C$ & 1.76E-06 & & & & & & & & & \\
\hline & & & & & & Consisten & & & & \\
\hline & & & & & & $u_{\text {ext }}$ & 0.001 & & & \\
\hline & & & & & & $R_{\mathrm{B}}$ & 0.862 & Birge ok & & \\
\hline & & & & & & Limit & 1.307 & & & \\
\hline
\end{tabular}

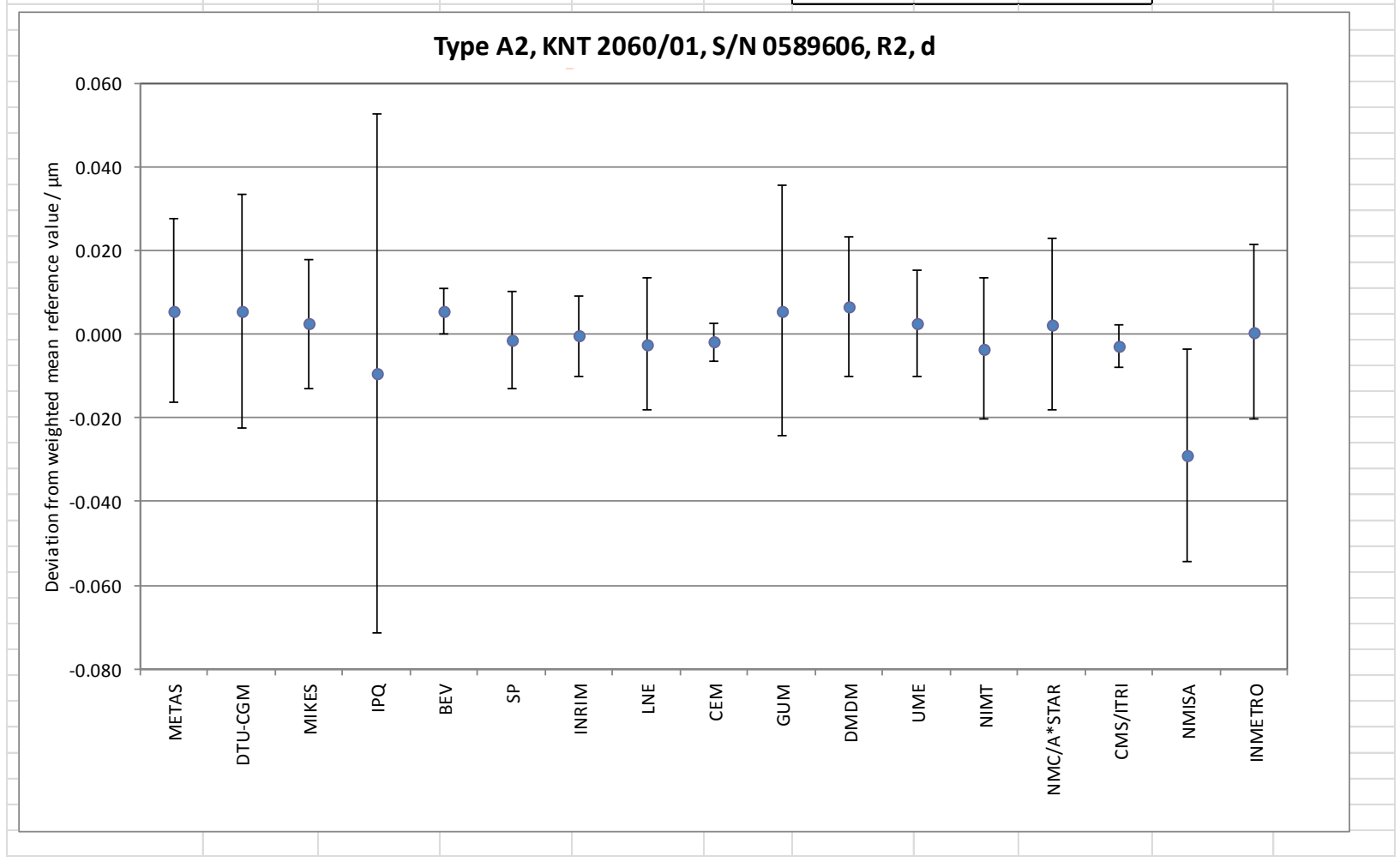




\begin{tabular}{|c|c|c|c|c|c|c|c|c|c|c|}
\hline \multirow[b]{2}{*}{ select gauge } & \multirow[b]{2}{*}{3} & & & & \multirow{2}{*}{\multicolumn{2}{|c|}{$\begin{array}{l}\text { use } 1 \text { or } 0 \text { to } \\
\text { in- or exclude }\end{array}$}} & \multirow{2}{*}{$\begin{array}{c}\text { choose: } \\
k=2\end{array}$} & \multirow[b]{3}{*}{$U\left(x_{i}-x_{\text {ref }}\right) / \mu \mathrm{m}$} & \multirow[b]{3}{*}{$E \mathrm{n}$} & \multirow[b]{3}{*}{$w_{i}$} \\
\hline & & \multicolumn{3}{|c|}{ Type A2, KNT 2060/01, S/N 0589606, R3, d } & & & & & & \\
\hline Institute & $x_{\mathrm{i}} / \mu \mathrm{m}$ & $\sigma_{i} / \mu \mathrm{m}$ & $u_{\mathrm{i}} / \mu \mathrm{m}$ & $v_{\text {eff }}$ & on/off & $\left(x_{i}-x_{\mathrm{w}}\right) / \mu \mathrm{m}$ & $k$ & & & \\
\hline METAS & 1.343 & 0.006 & 0.011 & 116 & 1 & 0.001 & 2.00 & 0.022 & 0.06 & 0.02 \\
\hline DTU-CGM & 1.346 & 0.003 & 0.015 & 10000 & 1 & 0.004 & 2.00 & 0.030 & 0.14 & 0.01 \\
\hline MIKES & 1.336 & 0.006 & 0.010 & 9 & 1 & -0.006 & 2.00 & 0.020 & 0.29 & 0.03 \\
\hline $\mathrm{IPQ}$ & 1.300 & 0.003 & 0.031 & 110 & 1 & -0.042 & 2.00 & 0.062 & 0.67 & 0.00 \\
\hline BEV & 1.350 & 0.003 & 0.003 & 10000 & 1 & 0.008 & 2.00 & 0.005 & 1.68 & 0.33 \\
\hline SP & 1.339 & 0.003 & 0.009 & 221 & 1 & -0.003 & 2.00 & 0.018 & 0.16 & 0.04 \\
\hline INRIM & 1.338 & 0.005 & 0.006 & 81 & 1 & -0.004 & 2.00 & 0.011 & 0.33 & 0.08 \\
\hline LNE & 1.335 & 0.018 & 0.013 & 67 & 1 & -0.007 & 2.00 & 0.026 & 0.26 & 0.02 \\
\hline CEM & 1.338 & 0.003 & 0.004 & 10000 & 1 & -0.004 & 2.00 & 0.007 & 0.52 & 0.19 \\
\hline GUM & 1.355 & 0.006 & 0.015 & 17 & 1 & 0.013 & 2.00 & 0.030 & 0.44 & 0.01 \\
\hline DMDM & 1.347 & 0.007 & 0.015 & 10000 & 1 & 0.005 & 2.00 & 0.031 & 0.17 & 0.01 \\
\hline UME & 1.341 & 0.002 & 0.008 & 454 & 1 & -0.001 & 2.00 & 0.016 & 0.05 & 0.05 \\
\hline NIMT & 1.326 & 0.002 & 0.012 & 311811 & 1 & -0.016 & 2.00 & 0.023 & 0.69 & 0.02 \\
\hline NMC/A*STAR & 1.340 & 0.004 & 0.010 & 10000 & 1 & -0.001 & 2.00 & 0.020 & 0.07 & 0.03 \\
\hline CMS/ITRI & 1.335 & 0.002 & 0.005 & 171 & 1 & -0.006 & 2.00 & 0.009 & 0.71 & 0.13 \\
\hline NMISA & 1.278 & 0.005 & 0.030 & 10000 & 1 & -0.064 & 2.00 & 0.060 & 1.07 & 0.00 \\
\hline INMETRO & 1.340 & 0.002 & 0.012 & 10000 & 1 & -0.002 & 2.00 & 0.023 & 0.10 & 0.02 \\
\hline & $x_{\mathrm{w}}$ & & $u\left(x_{w}\right)$ & $v_{\text {eff }}$ & $N-1$ & & $\boldsymbol{k}_{\text {ref }}$ & & & \\
\hline Reference value & 1.342 & & 0.002 & 3074 & 16 & & 2.00 & & & \\
\hline$C$ & $2.97 \mathrm{E}-06$ & & & & & & & & & \\
\hline & & & & & & Consisten & & & & \\
\hline & & & & & & $u_{\text {ext }}$ & 0.002 & & & \\
\hline & & & & & & $R_{\mathrm{B}}$ & 1.132 & Birge ok & & \\
\hline & & & & & & Limit & 1.307 & & & \\
\hline
\end{tabular}

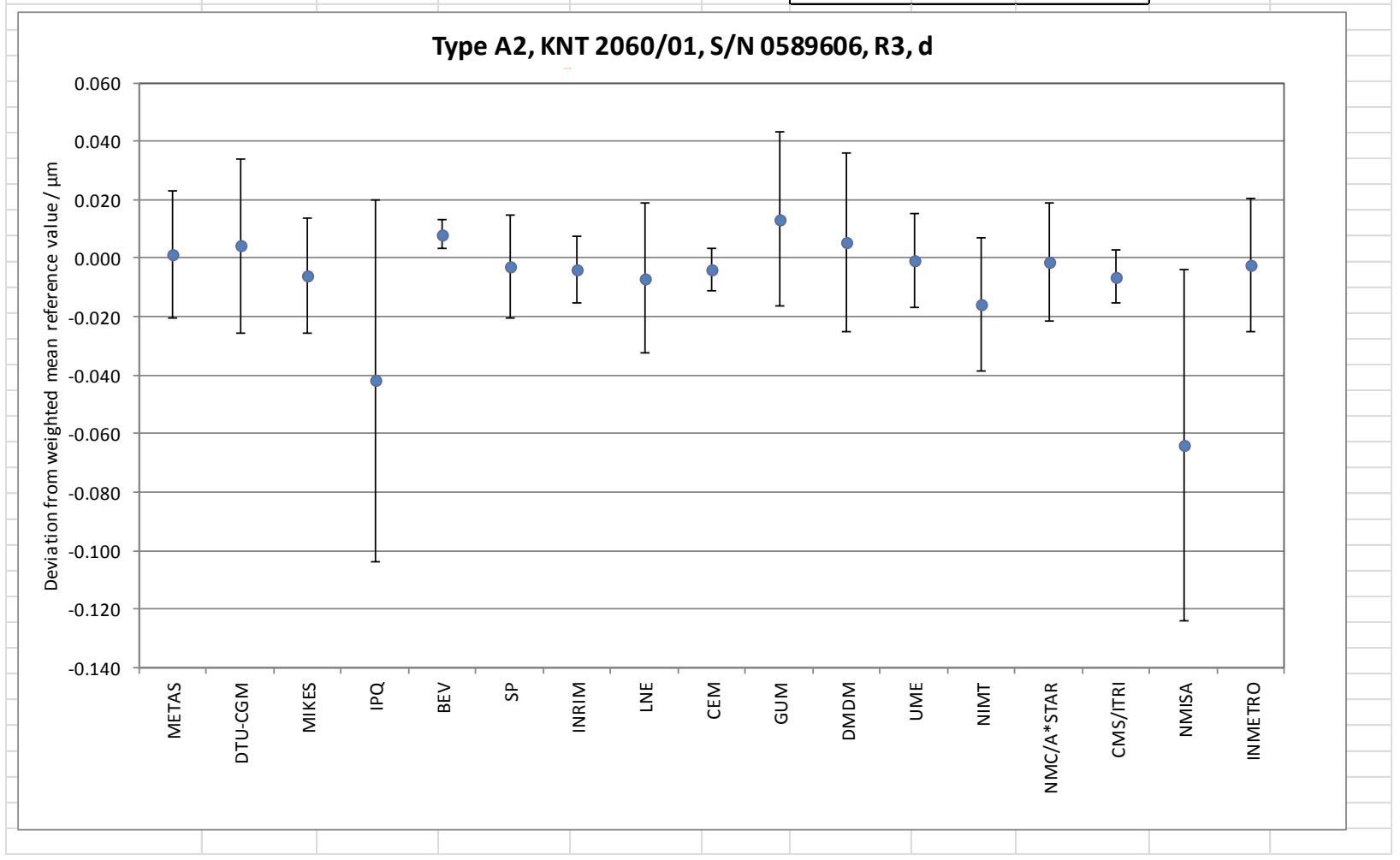




\begin{tabular}{|c|c|c|c|c|c|c|c|c|c|c|}
\hline \multirow[b]{2}{*}{ select gauge } & & \multirow{2}{*}{\multicolumn{3}{|c|}{ Type A2, KNT 2060/01, S/N 0589606, R4, d }} & \multirow{2}{*}{\multicolumn{2}{|c|}{$\begin{array}{l}\text { use } 1 \text { or } 0 \text { to } \\
\text { in- or exclude }\end{array}$}} & \multirow{2}{*}{$\begin{array}{c}\text { choose: } \\
k=2\end{array}$} & \multirow[b]{3}{*}{$U\left(x_{i}-x_{\text {ref }}\right) / \mu \mathrm{m}$} & \multirow[b]{3}{*}{$E \mathrm{n}$} & \multirow[b]{3}{*}{$w_{i}$} \\
\hline & $\Delta$ & & & & & & & & & \\
\hline Institute & $x_{\mathrm{i}} / \mu \mathrm{m}$ & $\sigma_{i} / \mu \mathrm{m}$ & $u_{\mathrm{i}} / \mu \mathrm{m}$ & $v_{\text {eff }}$ & on/off & $\left(x_{i}-x_{\mathrm{w}}\right) / \mu \mathrm{m}$ & $k$ & & & \\
\hline METAS & 2.713 & 0.008 & 0.011 & 99 & 1 & 0.002 & 2.00 & 0.022 & 0.09 & 0.03 \\
\hline DTU-CGM & 2.695 & 0.011 & 0.017 & 10000 & 1 & -0.016 & 2.00 & 0.034 & 0.47 & 0.01 \\
\hline MIKES & 2.711 & 0.007 & 0.016 & 9 & 1 & 0.000 & 2.00 & 0.031 & 0.00 & 0.01 \\
\hline $\mathrm{IPQ}$ & 2.640 & 0.004 & 0.031 & 111 & 1 & -0.071 & 2.00 & 0.062 & 1.15 & 0.00 \\
\hline BEV & 2.714 & 0.002 & 0.003 & 10000 & 1 & 0.003 & 2.00 & 0.003 & 0.92 & 0.57 \\
\hline SP & 2.712 & 0.004 & 0.020 & 545 & 1 & 0.001 & 2.00 & 0.040 & 0.03 & 0.01 \\
\hline INRIM & 2.710 & 0.011 & 0.008 & 81 & 1 & -0.001 & 2.00 & 0.016 & 0.06 & 0.06 \\
\hline LNE & 2.703 & 0.020 & 0.019 & 27 & 1 & -0.008 & 2.00 & 0.038 & 0.21 & 0.01 \\
\hline CEM & 2.708 & 0.007 & 0.005 & 10000 & 1 & -0.003 & 2.00 & 0.009 & 0.32 & 0.14 \\
\hline GUM & 2.709 & 0.004 & 0.015 & 21 & 1 & -0.002 & 2.00 & 0.030 & 0.07 & 0.02 \\
\hline DMDM & 2.709 & 0.015 & 0.022 & 10000 & 1 & -0.002 & 2.00 & 0.043 & 0.05 & 0.01 \\
\hline UME & 2.706 & 0.007 & 0.013 & 330 & 1 & -0.005 & 2.00 & 0.025 & 0.20 & 0.02 \\
\hline NIMT & 2.682 & 0.009 & 0.021 & 3149 & 1 & -0.029 & 2.00 & 0.042 & 0.69 & 0.01 \\
\hline NMC/A*STAR & 2.710 & 0.011 & 0.012 & 10000 & 1 & -0.001 & 2.00 & 0.023 & 0.06 & 0.03 \\
\hline CMS/ITRI & 2.702 & 0.009 & 0.009 & 129 & 1 & -0.009 & 2.00 & 0.018 & 0.53 & 0.04 \\
\hline NMISA & 2.647 & 0.008 & 0.058 & 10000 & 1 & -0.064 & 2.00 & 0.115 & 0.55 & 0.00 \\
\hline INMETRO & 2.717 & 0.017 & 0.013 & 10000 & 1 & 0.006 & 2.00 & 0.025 & 0.24 & 0.02 \\
\hline & $x_{\mathrm{w}}$ & & $u\left(x_{\mathrm{w}}\right)$ & $v_{\text {eff }}$ & $N-1$ & & $\boldsymbol{k}_{\text {ref }}$ & & & \\
\hline Reference value & 2.711 & & 0.002 & 7159 & 16 & & 2.00 & & & \\
\hline$C$ & $3.58 \mathrm{E}-06$ & & & & & & & & & \\
\hline & & & & & & Consisten & & & & \\
\hline & & & & & & $u_{\text {ext }}$ & 0.002 & & & \\
\hline & & & & & & $R_{\mathrm{B}}$ & 0.894 & Birge ok & & \\
\hline & & & & & & Limit & 1.307 & & & \\
\hline
\end{tabular}

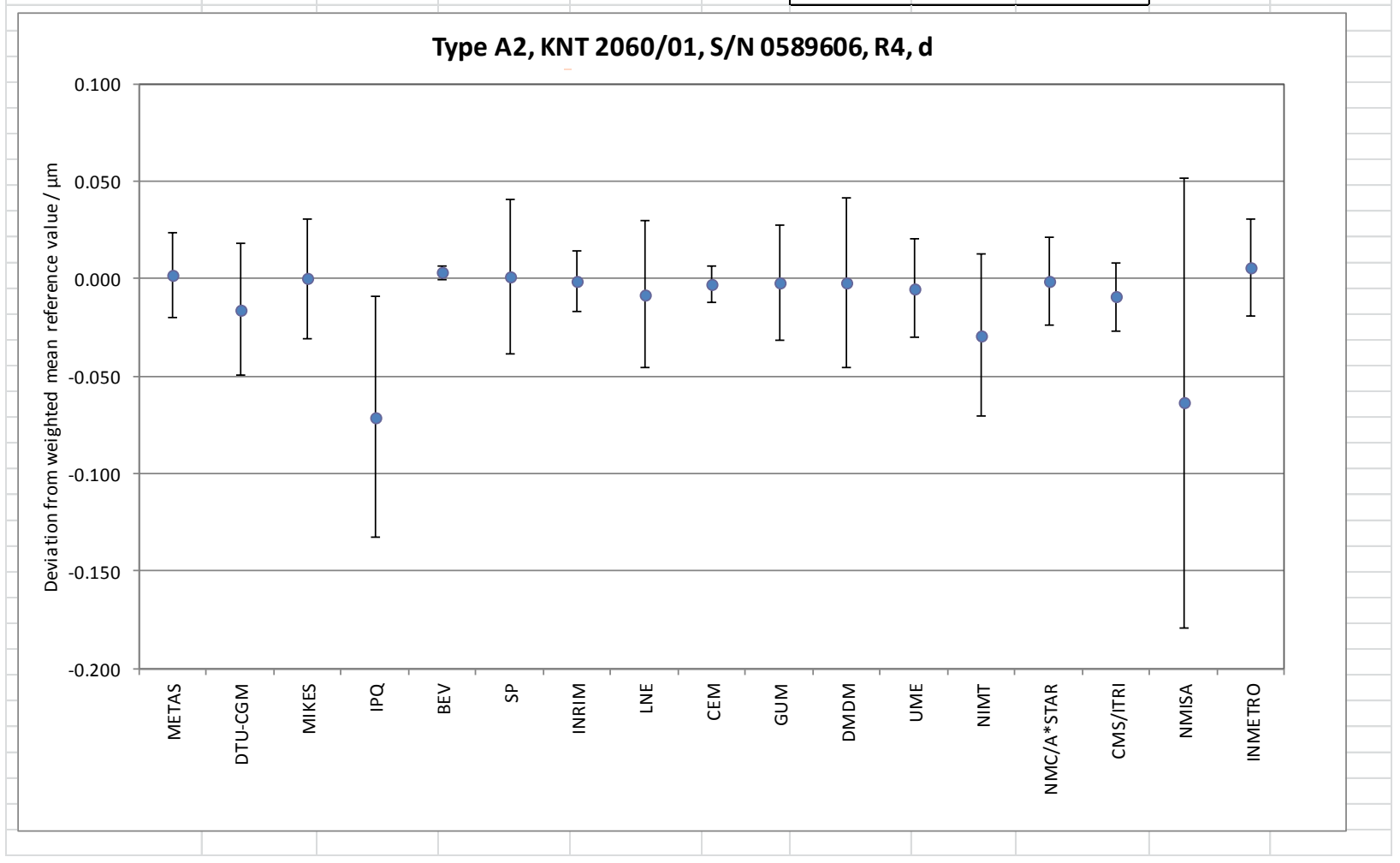




\begin{tabular}{|c|c|c|c|c|c|c|c|c|c|c|}
\hline \multirow[b]{2}{*}{ select gauge } & \multirow[b]{2}{*}{5} & & & & \multirow{2}{*}{\multicolumn{2}{|c|}{$\begin{array}{l}\text { use } 1 \text { or } 0 \text { to } \\
\text { in- or exclude }\end{array}$}} & \multirow{2}{*}{$\begin{array}{c}\text { choose: } \\
k=2\end{array}$} & \multirow[b]{3}{*}{$U\left(x_{i}-x_{\text {ref }}\right) / \mu \mathrm{m}$} & \multirow[b]{3}{*}{$E \mathrm{n}$} & \multirow[b]{3}{*}{$w_{i}$} \\
\hline & & \multicolumn{3}{|c|}{ Type A2, KNT 2060/01, S/N 0589606, R5, d } & & & & & & \\
\hline Institute & $x_{\mathrm{i}} / \mu \mathrm{m}$ & $\sigma_{i} / \mu \mathrm{m}$ & $u_{\mathrm{i}} / \mu \mathrm{m}$ & $v_{\text {eff }}$ & on/off & $\left(x_{i}-x_{\mathrm{w}}\right) / \mu \mathrm{m}$ & $k$ & & & \\
\hline METAS & 5.520 & 0.007 & 0.011 & 107 & 1 & 0.000 & 2.00 & 0.021 & 0.00 & 0.05 \\
\hline DTU-CGM & 5.506 & 0.013 & 0.033 & 10000 & 1 & -0.014 & 2.00 & 0.066 & 0.21 & 0.01 \\
\hline MIKES & 5.519 & 0.009 & 0.029 & 9 & 1 & -0.001 & 2.00 & 0.057 & 0.02 & 0.01 \\
\hline $\mathrm{IPQ}$ & 5.490 & 0.027 & 0.041 & 41 & 1 & -0.030 & 2.00 & 0.082 & 0.37 & 0.00 \\
\hline BEV & 5.520 & 0.003 & 0.003 & 10000 & 1 & 0.000 & 2.00 & 0.003 & 0.01 & 0.68 \\
\hline SP & 5.523 & 0.005 & 0.031 & 221 & 1 & 0.003 & 2.00 & 0.062 & 0.05 & 0.01 \\
\hline INRIM & 5.528 & 0.009 & 0.015 & 96 & 1 & 0.008 & 2.00 & 0.030 & 0.27 & 0.03 \\
\hline LNE & 5.521 & 0.021 & 0.034 & 16 & 1 & 0.001 & 2.00 & 0.068 & 0.01 & 0.01 \\
\hline CEM & 5.513 & 0.007 & 0.009 & 10000 & 1 & -0.007 & 2.00 & 0.016 & 0.43 & 0.08 \\
\hline GUM & 5.533 & 0.010 & 0.015 & 30 & 1 & 0.013 & 2.00 & 0.030 & 0.44 & 0.03 \\
\hline DMDM & 5.527 & 0.013 & 0.029 & 10000 & 1 & 0.007 & 2.00 & 0.057 & 0.12 & 0.01 \\
\hline UME & 5.523 & 0.008 & 0.023 & 242 & 1 & 0.003 & 2.00 & 0.046 & 0.07 & 0.01 \\
\hline NIMT & 5.468 & 0.009 & 0.038 & 34238 & 1 & -0.052 & 2.00 & 0.076 & 0.68 & 0.00 \\
\hline NMC/A*STAR & 5.527 & 0.016 & 0.014 & 10000 & 1 & 0.007 & 2.00 & 0.027 & 0.27 & 0.03 \\
\hline CMS/ITRI & 5.512 & 0.010 & 0.018 & 109 & 1 & -0.008 & 2.00 & 0.035 & 0.23 & 0.02 \\
\hline NMISA & 5.474 & 0.009 & 0.114 & 10000 & 1 & -0.046 & 2.00 & 0.228 & 0.20 & 0.00 \\
\hline INMETRO & 5.531 & 0.008 & 0.016 & 10000 & 1 & 0.011 & 2.00 & 0.031 & 0.37 & 0.03 \\
\hline & $x_{\mathrm{w}}$ & & $u\left(x_{\mathrm{w}}\right)$ & $v_{\text {eff }}$ & $N-1$ & & $\boldsymbol{k}_{\text {ref }}$ & & & \\
\hline Reference value & 5.520 & & 0.002 & 8602 & 16 & & 2.00 & & & \\
\hline$C$ & $6.12 \mathrm{E}-06$ & & & & & & & & & \\
\hline & & & & & & Consisten & & & & \\
\hline & & & & & & $u_{\text {ext }}$ & 0.001 & & & \\
\hline & & & & & & $R_{\mathrm{B}}$ & 0.589 & Birge ok & & \\
\hline & & & & & & Limit & 1.307 & & & \\
\hline
\end{tabular}

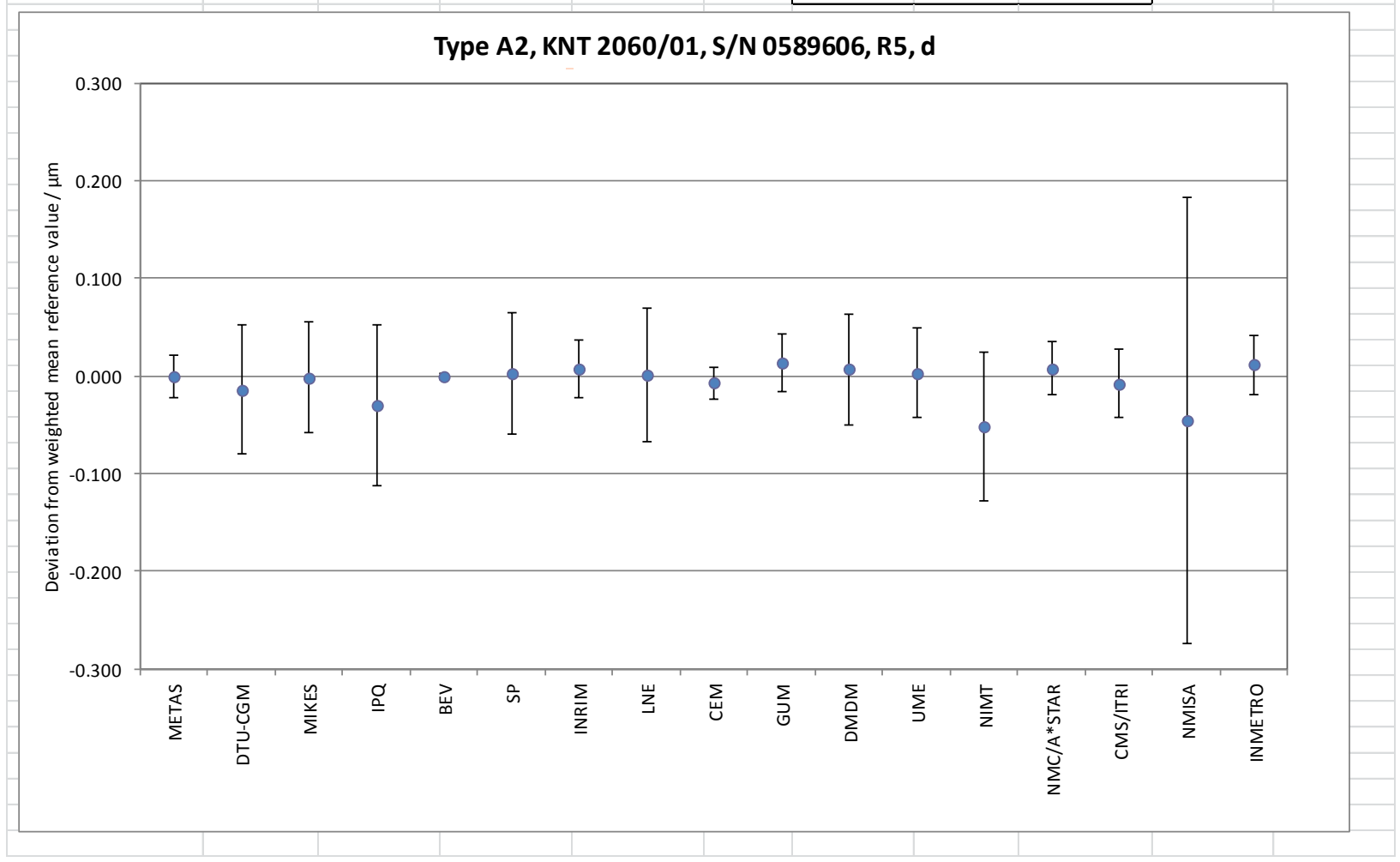




\begin{tabular}{|c|c|c|c|c|c|c|c|c|c|c|}
\hline \multirow[b]{2}{*}{ select gauge } & & & & & \multirow{2}{*}{\multicolumn{2}{|c|}{$\begin{array}{l}\text { use } 1 \text { or } 0 \text { to } \\
\text { in- or exclude }\end{array}$}} & \multirow{2}{*}{$\begin{array}{c}\text { choose: } \\
k=2\end{array}$} & \multirow[b]{3}{*}{$U\left(x_{i}-x_{\text {ref }}\right) / \mu \mathrm{m}$} & \multirow[b]{3}{*}{$E \mathrm{n}$} & \multirow[b]{3}{*}{$w_{i}$} \\
\hline & -7 & \multicolumn{3}{|c|}{ Type A2, KNT 2060/01, S/N 0589606, R6, d } & & & & & & \\
\hline Institute & $x_{\mathrm{i}} / \mu \mathrm{m}$ & $\sigma_{i} / \mu \mathrm{m}$ & $u_{\mathrm{i}} / \mu \mathrm{m}$ & $v_{\text {eff }}$ & on/off & $\left(x_{i}-x_{\mathrm{w}}\right) / \mu \mathrm{m}$ & $k$ & & & \\
\hline METAS & 8.915 & 0.020 & 0.014 & 20 & 1 & -0.010 & 2.00 & 0.028 & 0.35 & 0.03 \\
\hline DTU-CGM & 8.877 & 0.020 & 0.053 & 10000 & 1 & -0.048 & 2.00 & 0.106 & 0.45 & 0.00 \\
\hline MIKES & 8.920 & 0.017 & 0.045 & 9 & 1 & -0.005 & 2.00 & 0.090 & 0.05 & 0.00 \\
\hline $\mathrm{IPQ}$ & 8.860 & 0.023 & 0.038 & 56 & 1 & -0.065 & 2.00 & 0.076 & 0.85 & 0.00 \\
\hline BEV & 8.926 & 0.001 & 0.003 & 10000 & 1 & 0.001 & 2.00 & 0.002 & 0.77 & 0.87 \\
\hline SP & 8.934 & 0.001 & 0.047 & 159 & 1 & 0.009 & 2.00 & 0.094 & 0.10 & 0.00 \\
\hline INRIM & 8.925 & 0.032 & 0.031 & 88 & 1 & 0.000 & 2.00 & 0.062 & 0.01 & 0.01 \\
\hline LNE & 8.919 & 0.040 & 0.055 & 16 & 1 & -0.006 & 2.00 & 0.110 & 0.05 & 0.00 \\
\hline CEM & 8.910 & 0.026 & 0.015 & 10000 & 1 & -0.015 & 2.00 & 0.029 & 0.51 & 0.03 \\
\hline GUM & 8.926 & 0.013 & 0.020 & 43 & 1 & 0.001 & 2.00 & 0.040 & 0.03 & 0.01 \\
\hline DMDM & 8.924 & 0.028 & 0.045 & 10000 & 1 & -0.001 & 2.00 & 0.090 & 0.01 & 0.00 \\
\hline UME & 8.920 & 0.021 & 0.037 & 227 & 1 & -0.005 & 2.00 & 0.074 & 0.06 & 0.00 \\
\hline NIMT & 8.840 & 0.029 & 0.065 & 2495 & 1 & -0.085 & 2.00 & 0.130 & 0.65 & 0.00 \\
\hline NMC/A*STAR & 8.929 & 0.039 & 0.022 & 11 & 1 & 0.004 & 2.00 & 0.045 & 0.09 & 0.01 \\
\hline $\mathrm{CMS} / \mathrm{ITRI}$ & 8.912 & 0.028 & 0.029 & 113 & 1 & -0.013 & 2.00 & 0.057 & 0.22 & 0.01 \\
\hline NMISA & 8.852 & 0.030 & 0.184 & 10000 & 1 & -0.073 & 2.00 & 0.367 & 0.20 & 0.00 \\
\hline INMETRO & 8.922 & 0.019 & 0.019 & 10000 & 1 & -0.003 & 2.00 & 0.038 & 0.08 & 0.02 \\
\hline & $x_{\mathrm{w}}$ & & $u\left(x_{\mathrm{w}}\right)$ & $v_{\text {eff }}$ & $N-1$ & & $\boldsymbol{k}_{\text {ref }}$ & & & \\
\hline Reference value & 8.925 & & 0.002 & 7553 & 16 & & 2.00 & & & \\
\hline$C$ & $5.46 E-06$ & & & & & & & & & \\
\hline & & & & & & Consistenc & & & & \\
\hline & & & & & & $u_{\text {ext }}$ & 0.002 & & & \\
\hline & & & & & & $R_{\mathrm{B}}$ & 0.692 & Birge ok & & \\
\hline & & & & & & Limit & 1.307 & & & \\
\hline
\end{tabular}

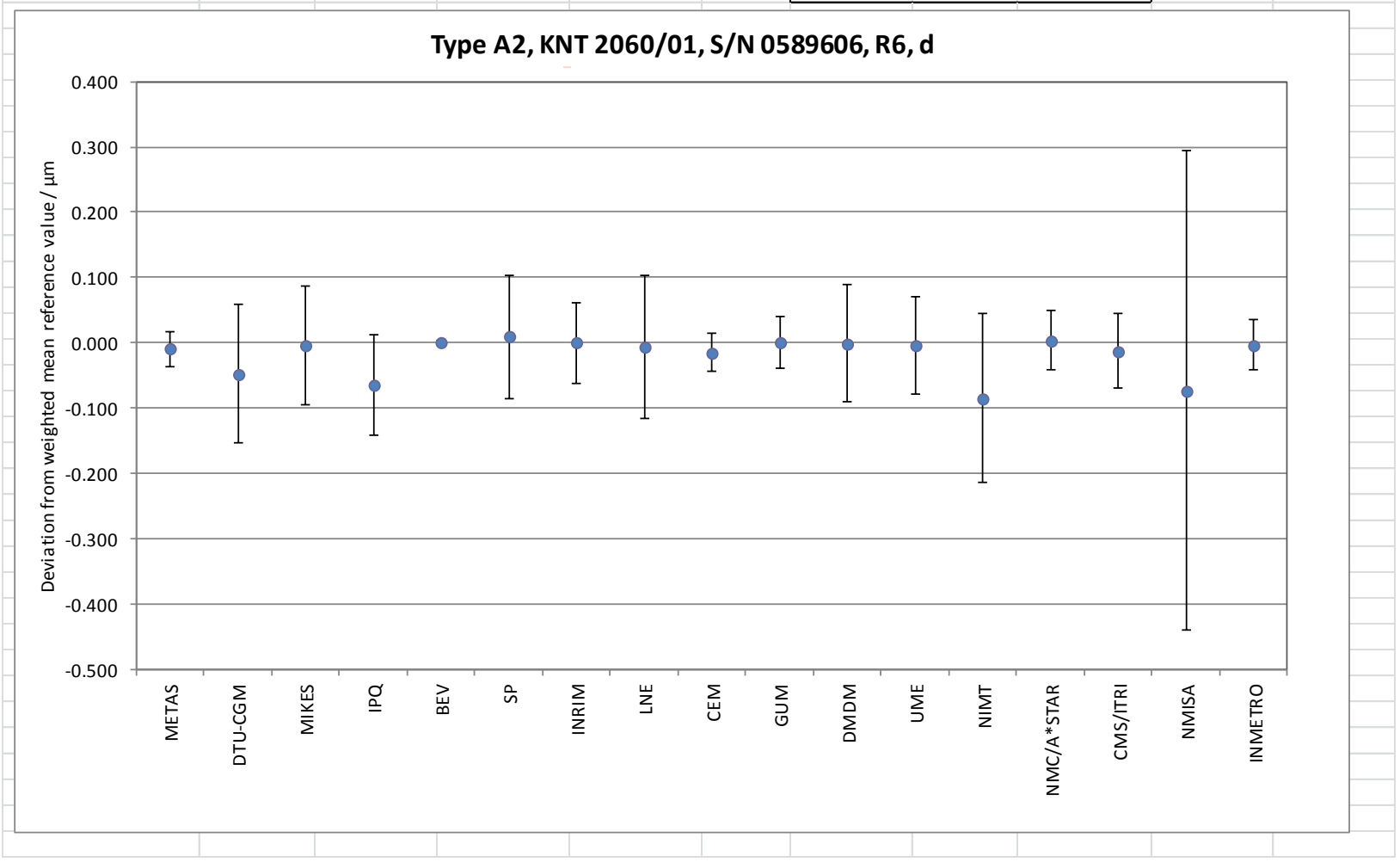




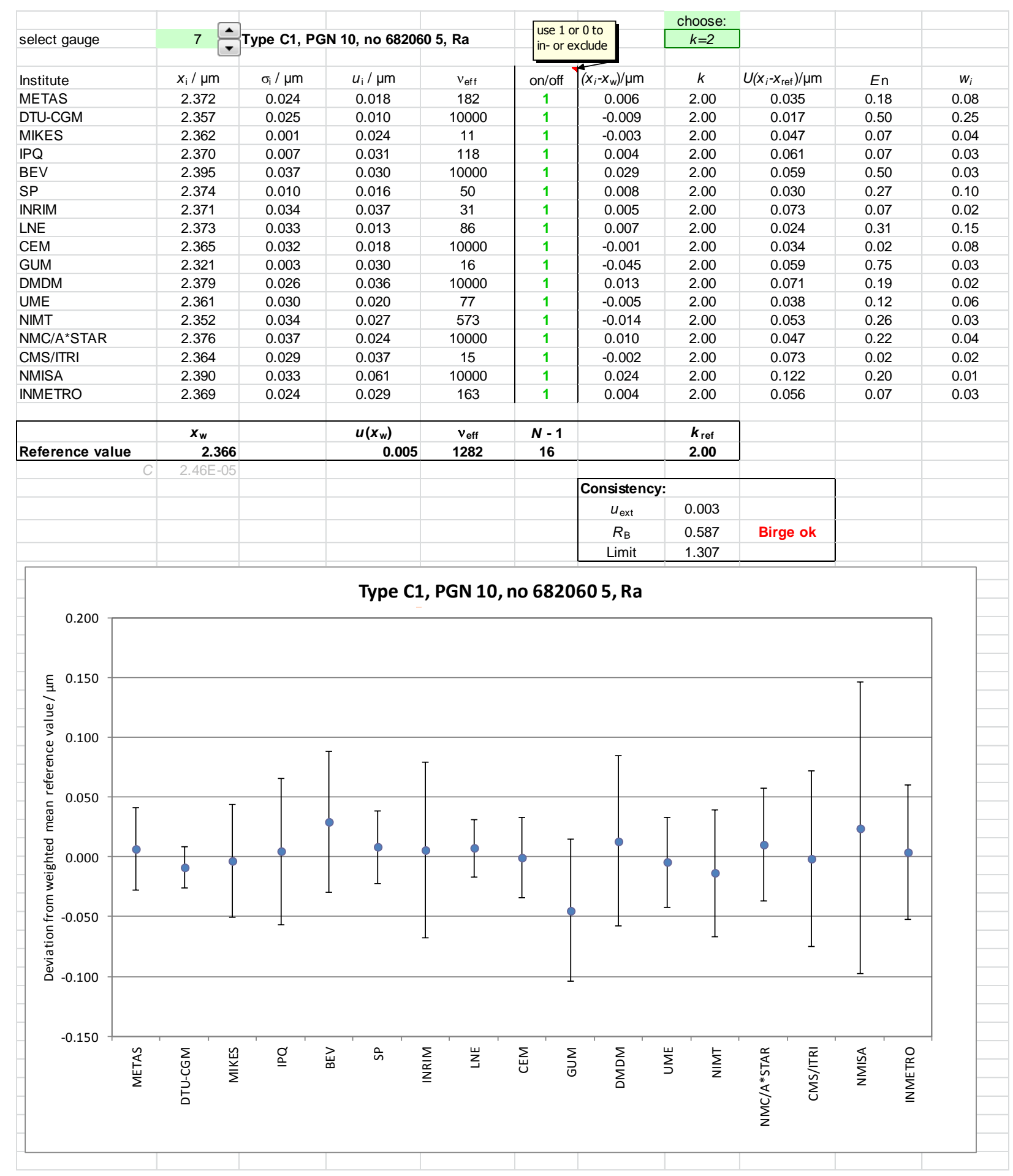




\begin{tabular}{|c|c|c|c|c|c|c|c|c|c|c|}
\hline & & & & & & & choose: & & & \\
\hline select gauge & $\frac{1}{-1}$ & Type C1, & 10 , no 68206 & , Rq & $\begin{array}{l}\text { use } 1 \\
\text { in- or }\end{array}$ & $\begin{array}{l}r 0 \text { to } \\
\text { xclude }\end{array}$ & $k=2$ & & & \\
\hline Institute & $x_{\mathrm{i}} / \mu \mathrm{m}$ & $\sigma_{i} / \mu \mathrm{m}$ & $u_{\mathrm{i}} / \mu \mathrm{m}$ & $v_{\text {eff }}$ & on/off & $\left(x_{i}-x_{\mathrm{w}}\right) / \mu \mathrm{m}$ & $k$ & $U\left(x_{i}-x_{\text {ref }}\right) / \mu m$ & En & $w_{i}$ \\
\hline METAS & 2.660 & 0.028 & 0.020 & 174 & 1 & 0.007 & 2.00 & 0.038 & 0.18 & 0.08 \\
\hline DTU-CGM & 2.645 & 0.030 & 0.012 & 10000 & 1 & -0.008 & 2.00 & 0.021 & 0.38 & 0.22 \\
\hline MIKES & 2.647 & 0.002 & 0.027 & 11 & 1 & -0.007 & 2.00 & 0.053 & 0.13 & 0.04 \\
\hline $\mathrm{IPQ}$ & 2.650 & 0.006 & 0.031 & 117 & 1 & -0.003 & 2.00 & 0.061 & 0.05 & 0.03 \\
\hline BEV & 2.685 & 0.043 & 0.030 & 10000 & 1 & 0.032 & 2.00 & 0.059 & 0.54 & 0.04 \\
\hline $\mathrm{SP}$ & 2.663 & 0.012 & 0.018 & 46 & 1 & 0.010 & 2.00 & 0.034 & 0.29 & 0.10 \\
\hline INRIM & 2.659 & 0.039 & 0.042 & 30 & 1 & 0.006 & 2.00 & 0.083 & 0.07 & 0.02 \\
\hline LNE & 2.661 & 0.038 & 0.015 & 90 & 1 & 0.008 & 2.00 & 0.028 & 0.29 & 0.14 \\
\hline CEM & 2.650 & 0.038 & 0.021 & 10000 & 1 & -0.003 & 2.00 & 0.040 & 0.08 & 0.07 \\
\hline GUM & 2.599 & 0.005 & 0.034 & 14 & 1 & -0.054 & 2.00 & 0.067 & 0.81 & 0.03 \\
\hline DMDM & 2.665 & 0.032 & 0.040 & 10000 & 1 & 0.012 & 2.00 & 0.080 & 0.15 & 0.02 \\
\hline UME & 2.646 & 0.036 & 0.022 & 77 & 1 & -0.007 & 2.00 & 0.043 & 0.17 & 0.07 \\
\hline NIMT & 2.638 & 0.040 & 0.033 & 684 & 1 & -0.015 & 2.00 & 0.065 & 0.23 & 0.03 \\
\hline NMC/A*STAR & 2.665 & 0.043 & 0.027 & 10000 & 1 & 0.012 & 2.00 & 0.053 & 0.23 & 0.04 \\
\hline CMS/ITRI & 2.650 & 0.034 & 0.043 & 15 & 1 & -0.003 & 2.00 & 0.085 & 0.04 & 0.02 \\
\hline NMISA & 2.680 & 0.040 & 0.070 & 10000 & 1 & 0.027 & 2.00 & 0.140 & 0.19 & 0.01 \\
\hline INMETRO & 2.655 & 0.028 & 0.032 & 100 & 1 & 0.001 & 2.00 & 0.062 & 0.02 & 0.03 \\
\hline & $x_{w}$ & & $u\left(x_{w}\right)$ & $v_{\text {eff }}$ & $N-1$ & & $\boldsymbol{k}_{\text {ref }}$ & & & \\
\hline Reference value & 2.653 & & 0.006 & 1194 & 16 & & 2.00 & & & \\
\hline C & 3.23E-05 & & & & & & & & & \\
\hline & & & & & & Consisten & & & & \\
\hline & & & & & & $u_{\text {ext }}$ & 0.003 & & & \\
\hline & & & & & & $R_{\mathrm{B}}$ & 0.596 & Birge ok & & \\
\hline & & & & & & Limit & 1.307 & & & \\
\hline
\end{tabular}

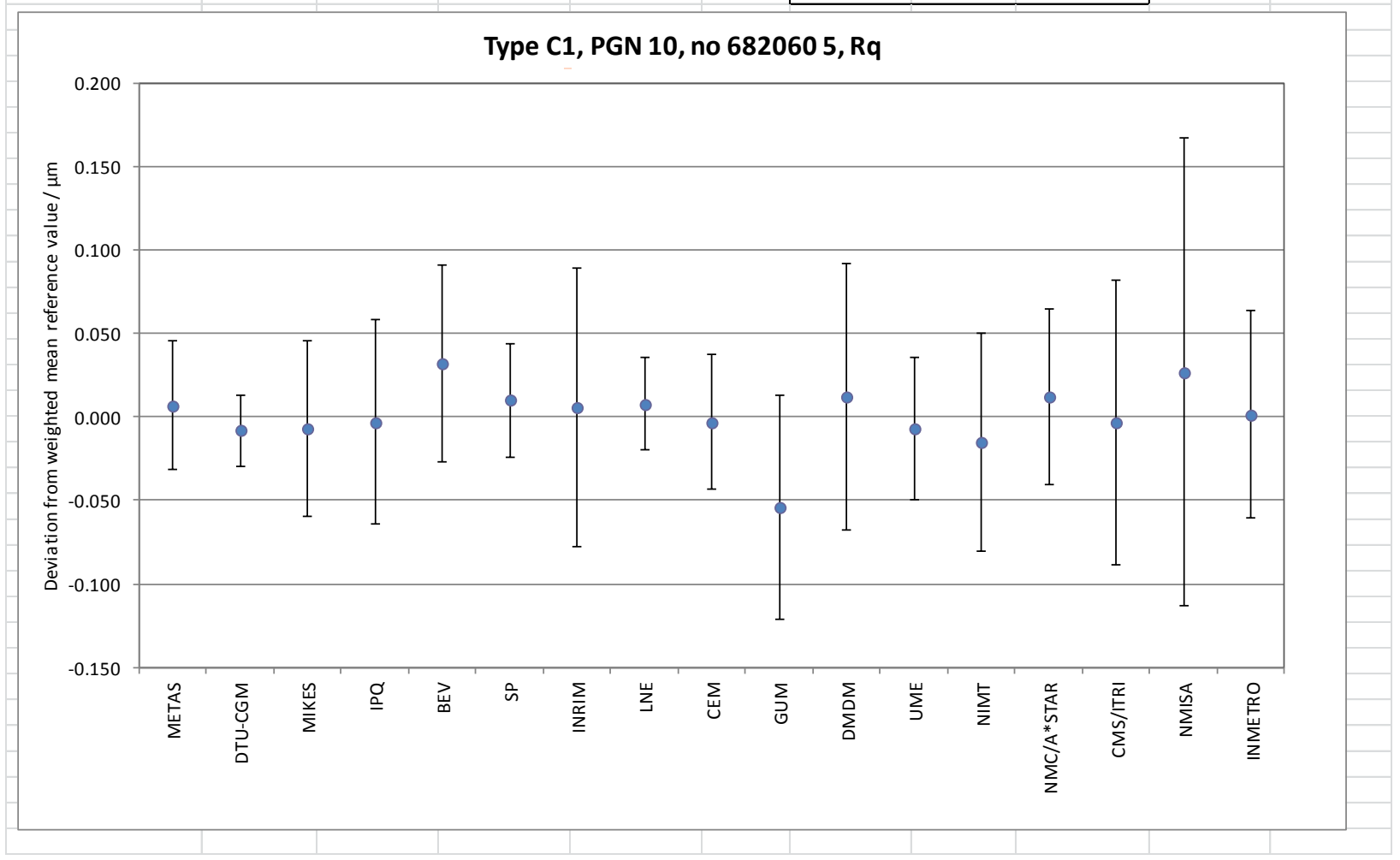




\begin{tabular}{|c|c|c|c|c|c|c|c|c|c|c|}
\hline \multirow[b]{2}{*}{ select gauge } & \multirow[b]{2}{*}{9} & \multirow{2}{*}{\multicolumn{3}{|c|}{ Type C1, PGN 10, no 682060 5, Rz }} & \multirow{2}{*}{\multicolumn{2}{|c|}{\begin{tabular}{|l|} 
use 1 or 0 to \\
in- or exclude
\end{tabular}}} & \multirow{2}{*}{$\begin{array}{c}\text { choose: } \\
k=2\end{array}$} & \multirow[b]{3}{*}{$U\left(x_{i}-x_{\text {ref }}\right) / \mu \mathrm{m}$} & \multirow[b]{3}{*}{$E \mathrm{n}$} & \multirow[b]{3}{*}{$w_{i}$} \\
\hline & & & & & & & & & & \\
\hline Institute & $x_{\mathrm{i}} / \mu \mathrm{m}$ & $\sigma_{i} / \mu m$ & $u_{\mathrm{i}} / \mu \mathrm{m}$ & $v_{\text {eff }}$ & on/off & $\left(x_{i}-x_{\mathrm{w}}\right) / \mu \mathrm{m}$ & $k$ & & & \\
\hline METAS & 7.700 & 0.100 & 0.060 & 164 & 1 & 0.032 & 2.00 & 0.116 & 0.28 & 0.07 \\
\hline DTU-CGM & 7.637 & 0.099 & 0.035 & 10000 & 1 & -0.031 & 2.00 & 0.063 & 0.49 & 0.20 \\
\hline MIKES & 7.639 & 0.017 & 0.077 & 11 & 1 & -0.029 & 2.00 & 0.152 & 0.19 & 0.04 \\
\hline $\mathrm{IPQ}$ & 7.630 & 0.015 & 0.034 & 164 & 1 & -0.038 & 2.00 & 0.060 & 0.63 & 0.21 \\
\hline BEV & 8.042 & 0.165 & 0.180 & 10000 & 1 & 0.374 & 2.00 & 0.359 & 1.04 & 0.01 \\
\hline SP & 7.720 & 0.039 & 0.053 & 35 & 1 & 0.052 & 2.00 & 0.101 & 0.52 & 0.09 \\
\hline INRIM & 7.703 & 0.134 & 0.139 & 24 & 1 & 0.035 & 2.00 & 0.276 & 0.13 & 0.01 \\
\hline LNE & 7.715 & 0.127 & 0.045 & 23 & 1 & 0.047 & 2.00 & 0.084 & 0.56 & 0.12 \\
\hline CEM & 7.661 & 0.132 & 0.073 & 10000 & 1 & -0.007 & 2.00 & 0.143 & 0.05 & 0.05 \\
\hline GUM & 7.575 & 0.028 & 0.097 & 10 & 1 & -0.093 & 2.00 & 0.191 & 0.48 & 0.03 \\
\hline DMDM & 7.704 & 0.109 & 0.154 & 10000 & 1 & 0.036 & 2.00 & 0.307 & 0.12 & 0.01 \\
\hline UME & 7.651 & 0.133 & 0.063 & 77 & 1 & -0.017 & 2.00 & 0.123 & 0.14 & 0.06 \\
\hline NIMT & 7.664 & 0.135 & 0.134 & 1517 & 1 & -0.004 & 2.00 & 0.266 & 0.01 & 0.01 \\
\hline NMC/A*STAR & 7.737 & 0.152 & 0.082 & 10000 & 1 & 0.069 & 2.00 & 0.161 & 0.43 & 0.04 \\
\hline $\mathrm{CMS} / \mathrm{ITRI}$ & 7.651 & 0.120 & 0.147 & 13 & 1 & -0.017 & 2.00 & 0.292 & 0.06 & 0.01 \\
\hline NMISA & 7.777 & 0.153 & 0.221 & 10000 & 1 & 0.109 & 2.00 & 0.441 & 0.25 & 0.01 \\
\hline \multirow[t]{2}{*}{ INMETRO } & 7.672 & 0.097 & 0.082 & 40 & 1 & 0.004 & 2.00 & 0.160 & 0.03 & 0.04 \\
\hline & $x_{\mathrm{w}}$ & & $u\left(x_{\mathrm{w}}\right)$ & $v_{\text {eff }}$ & $N-1$ & & $\boldsymbol{k}_{\text {ref }}$ & & & \\
\hline Reference value & 7.668 & & 0.016 & 671 & 16 & & 2.00 & & & \\
\hline \multirow[t]{5}{*}{ 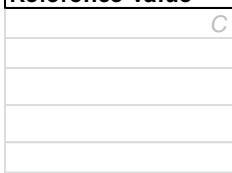 } & $2.46 E-04$ & & & & & & & & & \\
\hline & & & & & & \multicolumn{2}{|c|}{ Consistency: } & & & \\
\hline & & & & & & $u_{\text {ext }}$ & 0.013 & & & \\
\hline & & & & & & $R_{\mathrm{B}}$ & 0.826 & Birge ok & & \\
\hline & & & & & & Limit & 1.307 & & & \\
\hline
\end{tabular}

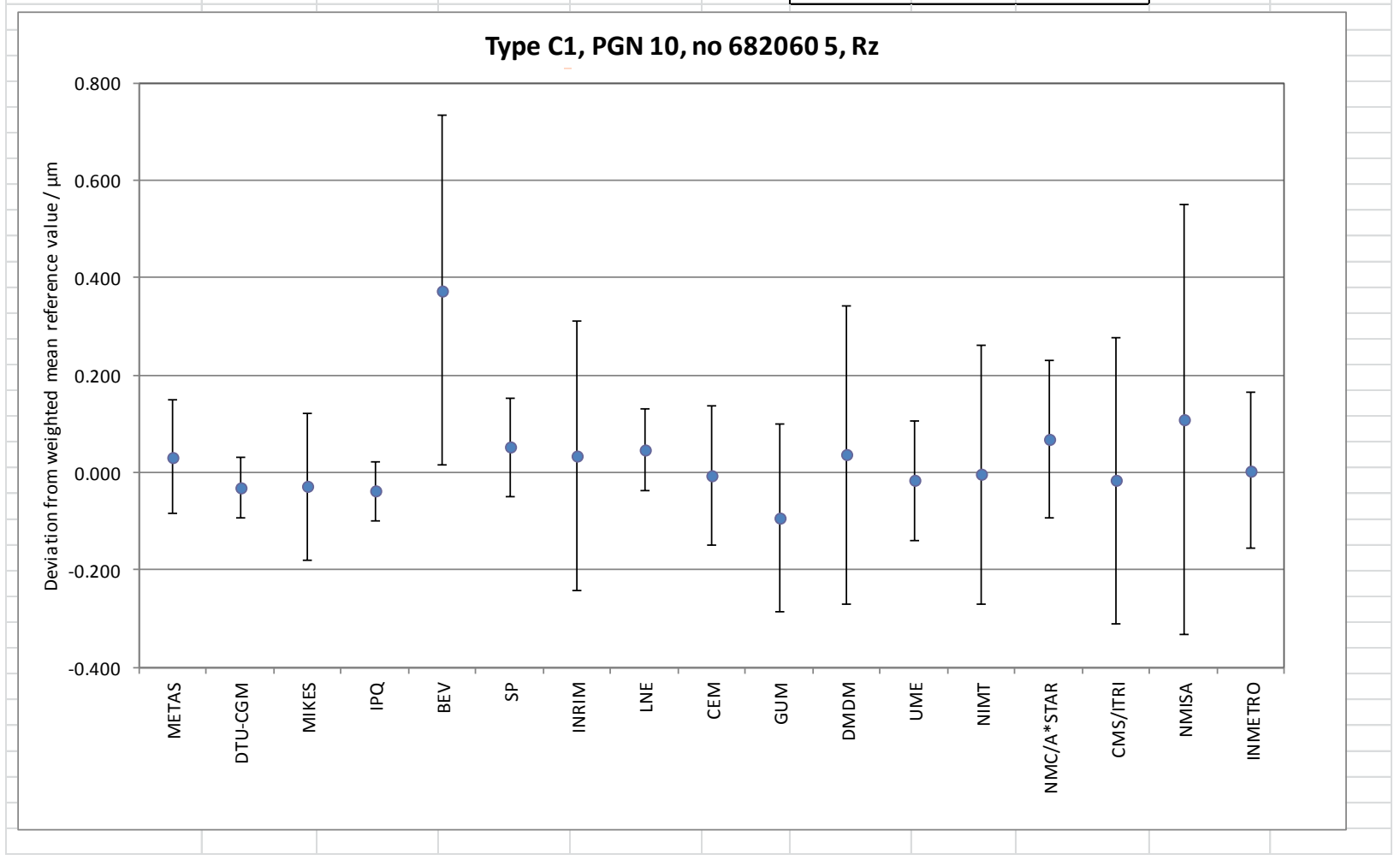




\begin{tabular}{|c|c|c|c|c|c|c|c|c|c|c|}
\hline \multirow[b]{2}{*}{ select gauge } & \multirow[b]{2}{*}{10} & \multirow{2}{*}{\multicolumn{3}{|c|}{ Type C1, PGN 10, no 682060 5, Rt }} & \multirow{2}{*}{\multicolumn{2}{|c|}{\begin{tabular}{|l} 
use 1 or 0 to \\
in- or exclude
\end{tabular}}} & \multirow{2}{*}{$\begin{array}{c}\text { choose: } \\
k=2\end{array}$} & & \multirow[b]{3}{*}{ En } & \multirow[b]{3}{*}{$w_{i}$} \\
\hline & & & & & & & & & & \\
\hline Institute & $x_{\mathrm{i}} / \mu \mathrm{m}$ & $\sigma_{i} / \mu m$ & $u_{\mathrm{i}} / \mu \mathrm{m}$ & $v_{\text {eff }}$ & on/off & $\left(x_{i}-x_{\mathrm{w}}\right) / \mu \mathrm{m}$ & $k$ & $U\left(x_{i}-x_{\text {ref }}\right) / \mu \mathrm{m}$ & & \\
\hline METAS & 7.760 & 0.110 & 0.070 & 131 & 1 & 0.024 & 2.00 & 0.136 & 0.18 & 0.06 \\
\hline DTU-CGM & 7.698 & 0.109 & 0.038 & 10000 & 1 & -0.038 & 2.00 & 0.068 & 0.55 & 0.20 \\
\hline MIKES & 7.691 & 0.024 & 0.078 & 11 & 1 & -0.045 & 2.00 & 0.152 & 0.29 & 0.05 \\
\hline IPQ & 7.700 & 0.026 & 0.040 & 284 & 1 & -0.036 & 2.00 & 0.072 & 0.49 & 0.18 \\
\hline BEV & 8.177 & 0.190 & 0.180 & 10000 & 1 & 0.441 & 2.00 & 0.358 & 1.23 & 0.01 \\
\hline SP & 7.780 & 0.040 & 0.055 & 32 & 1 & 0.044 & 2.00 & 0.105 & 0.42 & 0.09 \\
\hline INRIM & 7.767 & 0.142 & 0.139 & 24 & 1 & 0.031 & 2.00 & 0.276 & 0.11 & 0.01 \\
\hline LNE & 7.778 & 0.134 & 0.047 & 23 & 1 & 0.042 & 2.00 & 0.088 & 0.48 & 0.13 \\
\hline CEM & 7.726 & 0.148 & 0.082 & 10000 & 1 & -0.010 & 2.00 & 0.159 & 0.06 & 0.04 \\
\hline GUM & 7.694 & 0.028 & 0.098 & 10 & 1 & -0.042 & 2.00 & 0.193 & 0.22 & 0.03 \\
\hline DMDM & 7.777 & 0.122 & 0.156 & 10000 & 1 & 0.041 & 2.00 & 0.310 & 0.13 & 0.01 \\
\hline UME & 7.721 & 0.140 & 0.064 & 77 & 1 & -0.015 & 2.00 & 0.124 & 0.12 & 0.07 \\
\hline NIMT & 7.735 & 0.145 & 0.141 & 1404 & 1 & -0.001 & 2.00 & 0.280 & 0.00 & 0.01 \\
\hline NMC/A*STAR & 7.800 & 0.165 & 0.085 & 10000 & 1 & 0.064 & 2.00 & 0.167 & 0.39 & 0.04 \\
\hline CMS/ITRI & 7.720 & 0.131 & 0.159 & 13 & 1 & -0.016 & 2.00 & 0.316 & 0.05 & 0.01 \\
\hline NMISA & 7.838 & 0.157 & 0.225 & 10000 & 1 & 0.102 & 2.00 & 0.449 & 0.23 & 0.01 \\
\hline \multirow[t]{2}{*}{ INMETRO } & 7.727 & 0.110 & 0.082 & 17 & 1 & -0.009 & 2.00 & 0.160 & 0.05 & 0.04 \\
\hline & $x_{\mathrm{w}}$ & & $u\left(x_{w}\right)$ & $v_{\text {eff }}$ & $N-1$ & & $\boldsymbol{k}_{\text {ref }}$ & & & \\
\hline Reference value & 7.736 & & 0.017 & 611 & 16 & & 2.00 & & & \\
\hline \multirow[t]{5}{*}{$C$} & $2.87 \mathrm{E}-04$ & & & & & & & & & \\
\hline & & & & & & \multicolumn{2}{|c|}{ Consistency: } & & & \\
\hline & & & & & & $u_{\mathrm{ext}}$ & 0.014 & & & \\
\hline & & & & & & $R_{\mathrm{B}}$ & 0.824 & Birge ok & & \\
\hline & & & & & & Limit & 1.307 & & & \\
\hline
\end{tabular}

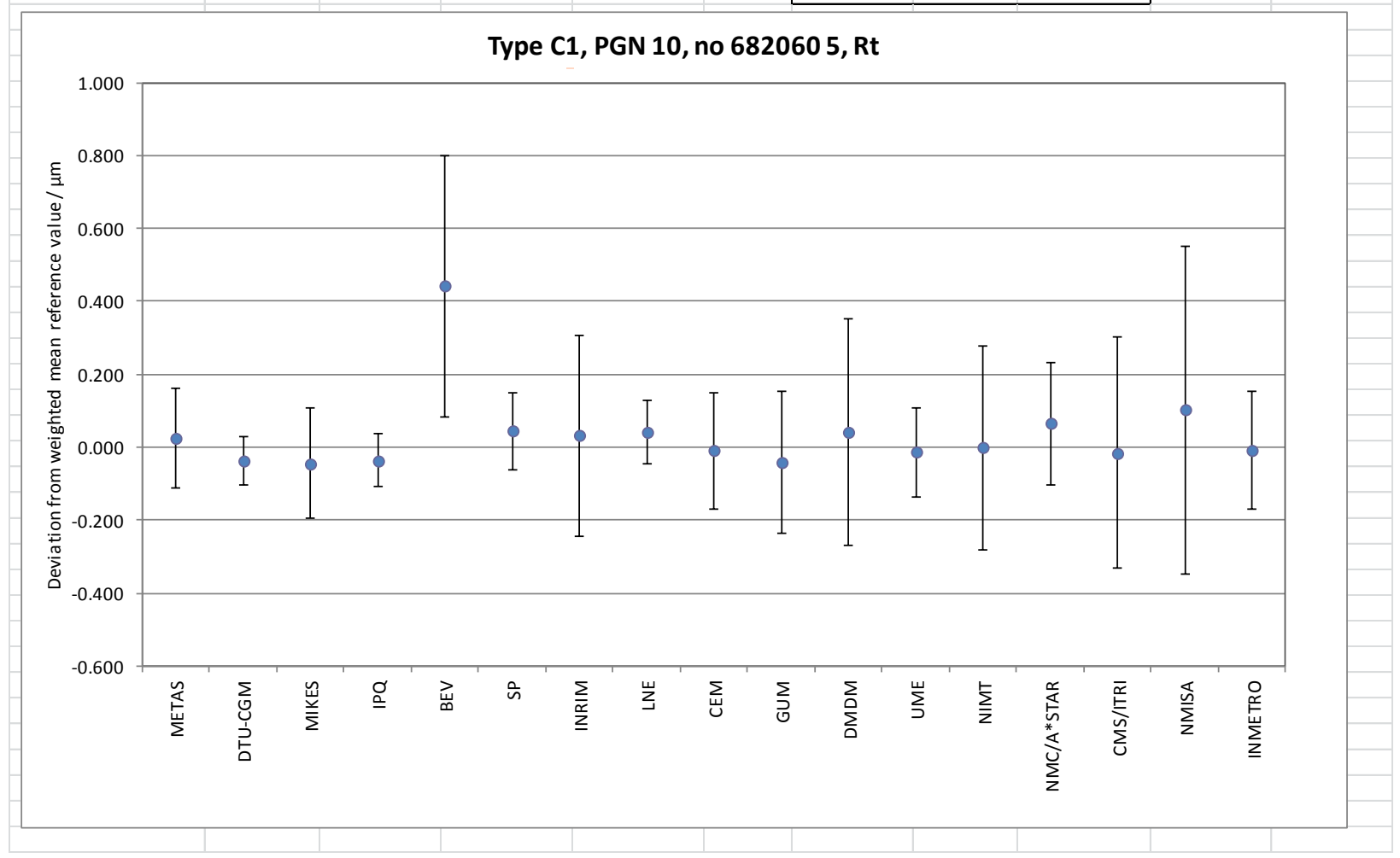




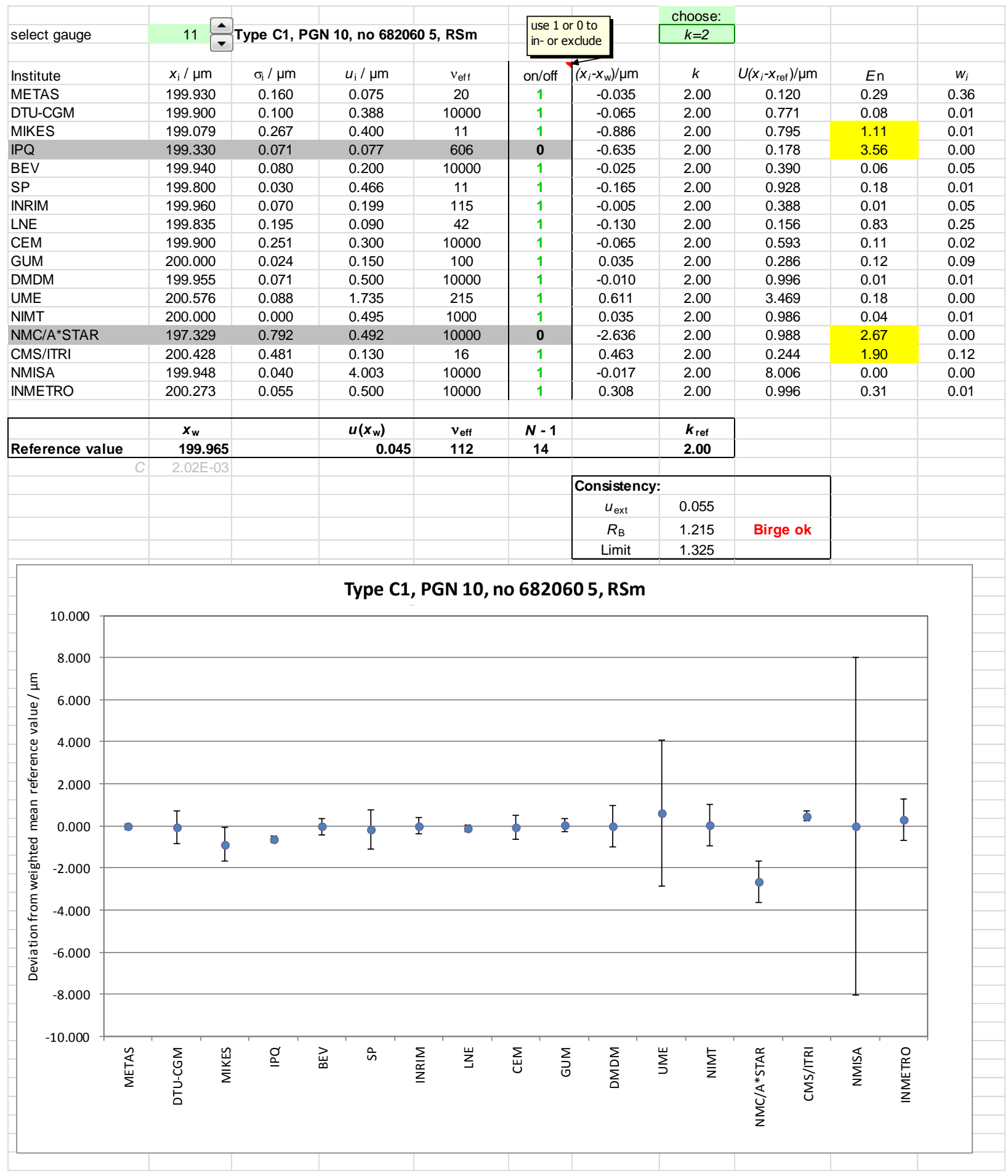




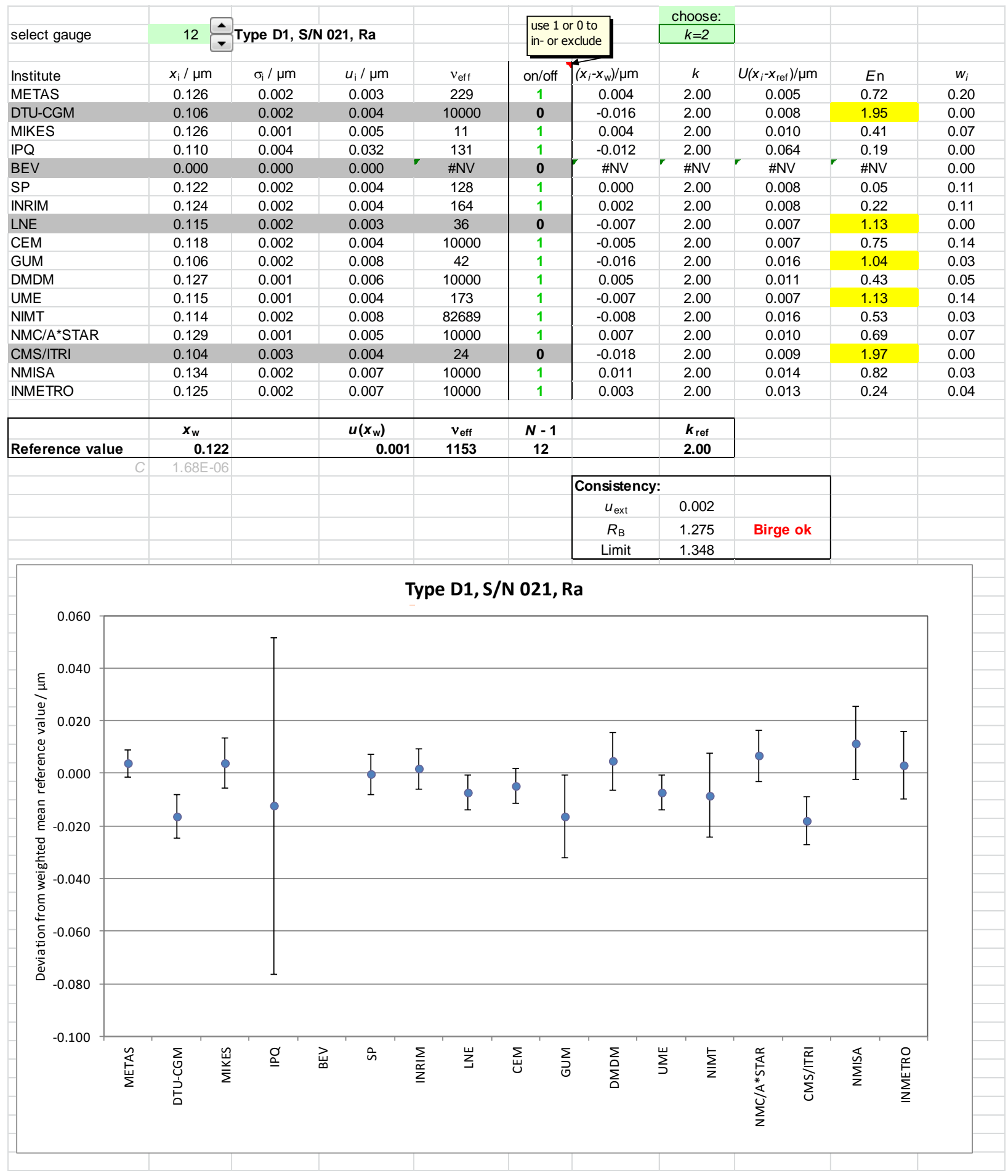




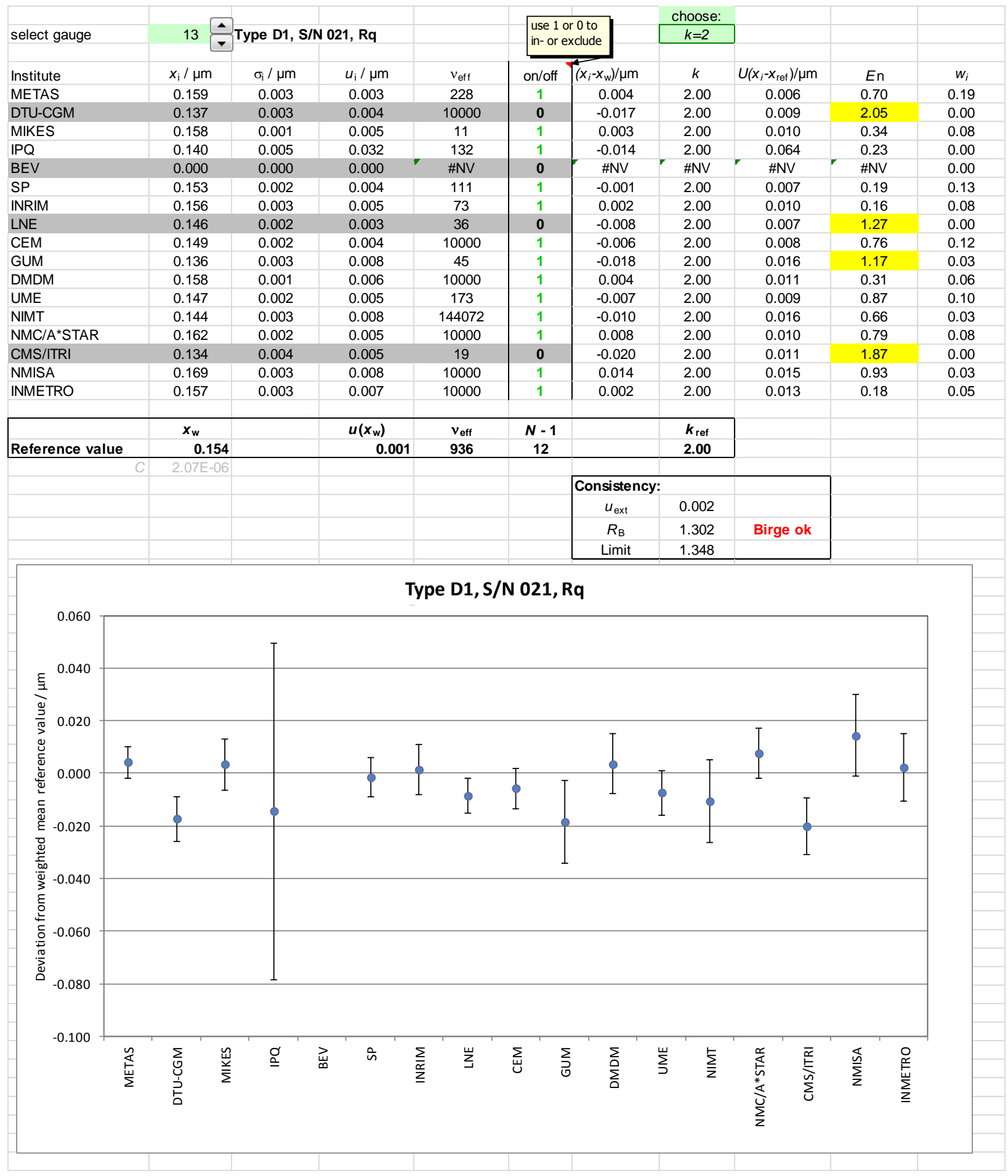




\begin{tabular}{|c|c|c|c|c|c|c|c|c|c|c|}
\hline \multirow[b]{2}{*}{ select gauge } & \multirow[b]{2}{*}{14} & \multirow{2}{*}{\multicolumn{2}{|c|}{ Type D1, S/N 021, Rz }} & & \multirow{2}{*}{\multicolumn{2}{|c|}{\begin{tabular}{|l|} 
use 1 or 0 to \\
in- or exclude
\end{tabular}}} & choose: & \multirow[b]{3}{*}{$U\left(x_{i}-x_{\mathrm{ref}}\right) / \mu \mathrm{m}$} & \multirow[b]{3}{*}{ En } & \multirow[b]{3}{*}{$w_{i}$} \\
\hline & & & & & & & $k=2$ & & & \\
\hline Institute & $x_{\mathrm{i}} / \mu \mathrm{m}$ & $\sigma_{i} / \mu \mathrm{m}$ & $u_{\mathrm{i}} / \mu \mathrm{m}$ & $v_{\text {eff }}$ & on/off & {$\left[\left(x_{i}-x_{\mathrm{w}}\right) / \mu \mathrm{m}\right.$} & $k$ & & & \\
\hline METAS & 1.056 & 0.050 & 0.039 & 162 & 1 & 0.045 & 2.00 & 0.077 & 0.59 & 0.02 \\
\hline DTU-CGM & 0.952 & 0.049 & 0.017 & 10000 & 0 & -0.059 & 2.00 & 0.036 & 1.62 & 0.00 \\
\hline MIKES & 1.019 & 0.031 & 0.016 & 11 & 1 & 0.008 & 2.00 & 0.030 & 0.27 & 0.14 \\
\hline $\mathrm{IPQ}$ & 0.990 & 0.045 & 0.055 & 128 & 1 & -0.021 & 2.00 & 0.109 & 0.19 & 0.01 \\
\hline BEV & 0.000 & 0.000 & 0.000 & \#NV & 0 & \#NV & \#NV & \#NV & \#NV & 0.00 \\
\hline SP & 1.016 & 0.013 & 0.014 & 16 & 1 & 0.005 & 2.00 & 0.025 & 0.21 & 0.19 \\
\hline INRIM & 1.047 & 0.046 & 0.046 & 14 & 1 & 0.036 & 2.00 & 0.091 & 0.40 & 0.02 \\
\hline LNE & 0.992 & 0.020 & 0.012 & 67 & 1 & -0.019 & 2.00 & 0.021 & 0.90 & 0.26 \\
\hline CEM & 1.021 & 0.045 & 0.025 & 10000 & 1 & 0.010 & 2.00 & 0.047 & 0.22 & 0.06 \\
\hline GUM & 0.898 & 0.026 & 0.034 & 87 & 0 & -0.113 & 2.00 & 0.069 & 1.63 & 0.00 \\
\hline DMDM & 1.011 & 0.022 & 0.027 & 10000 & 1 & 0.000 & 2.00 & 0.053 & 0.01 & 0.05 \\
\hline UME & 0.995 & 0.043 & 0.031 & 173 & 1 & -0.016 & 2.00 & 0.060 & 0.26 & 0.04 \\
\hline NIMT & 0.945 & 0.033 & 0.040 & 1002 & 1 & -0.066 & 2.00 & 0.079 & 0.83 & 0.02 \\
\hline NMC/A*STAR & 1.072 & 0.048 & 0.021 & 10000 & 0 & 0.061 & 2.00 & 0.044 & 1.40 & 0.00 \\
\hline CMS/ITRI & 0.917 & 0.041 & 0.049 & 13 & 1 & -0.094 & 2.00 & 0.097 & 0.96 & 0.02 \\
\hline NMISA & 1.100 & 0.037 & 0.045 & 10000 & 1 & 0.089 & 2.00 & 0.089 & 1.00 & 0.02 \\
\hline \multirow[t]{2}{*}{ INMETRO } & 1.027 & 0.035 & 0.016 & 10000 & 1 & 0.016 & 2.00 & 0.029 & 0.56 & 0.15 \\
\hline & $x_{w}$ & & $u\left(x_{w}\right)$ & $v_{\text {eff }}$ & $N-1$ & & $\boldsymbol{k}_{\text {ref }}$ & & & \\
\hline Reference value & 1.011 & & 0.006 & 197 & 12 & & 2.00 & & & \\
\hline \multirow[t]{5}{*}{$C$} & 3.68E-05 & & & & & & & & & \\
\hline & & & & & & \multicolumn{2}{|c|}{ Consistency: } & & & \\
\hline & & & & & & $u_{\text {ext }}$ & 0.007 & & & \\
\hline & & & & & & $R_{\mathrm{B}}$ & 1.180 & Birge ok & & \\
\hline & & & & & & Limit & 1.348 & & & \\
\hline
\end{tabular}

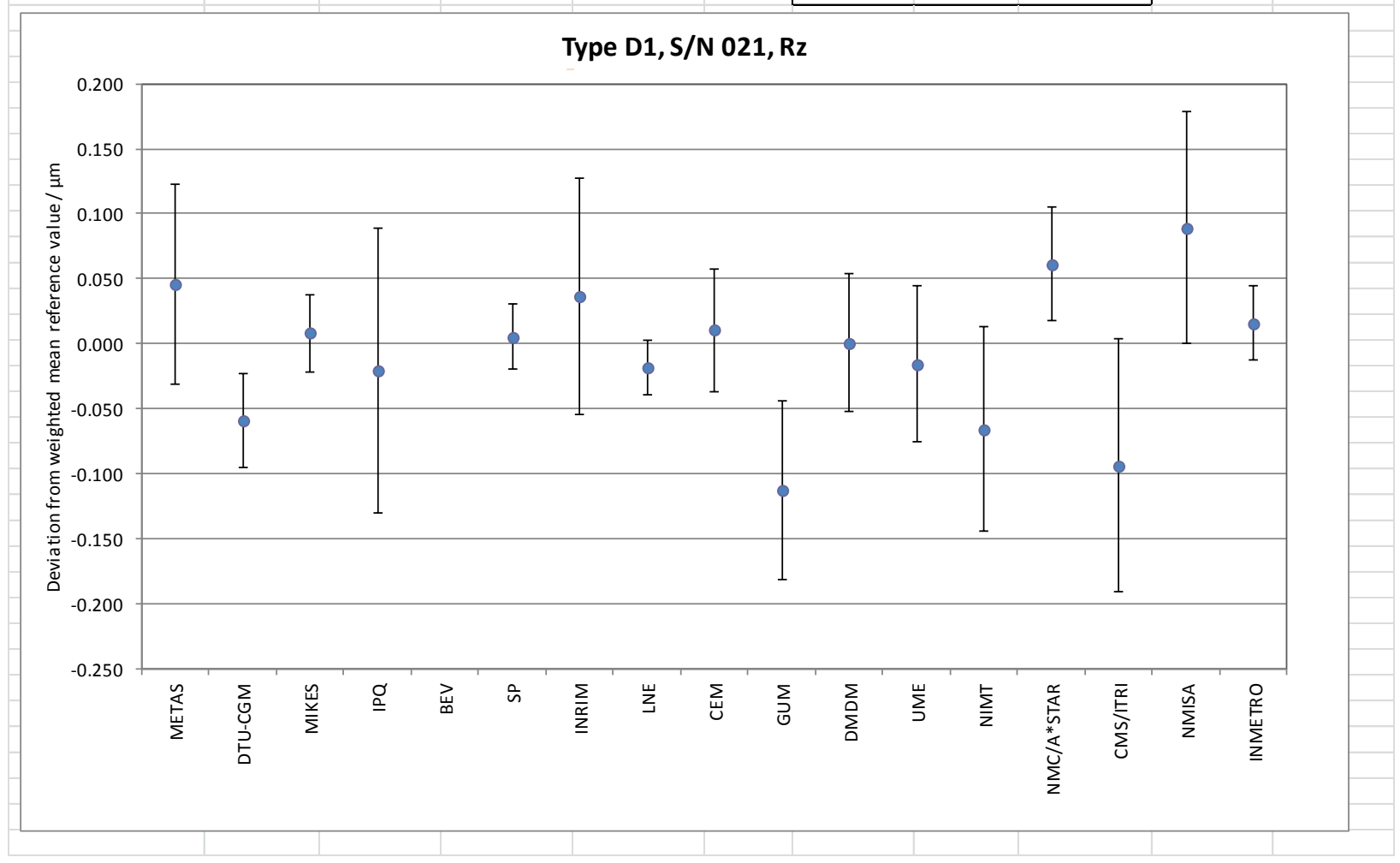




\begin{tabular}{|c|c|c|c|c|c|c|c|c|c|c|}
\hline \multirow[b]{2}{*}{ select gauge } & \multirow[b]{2}{*}{15} & \multirow{2}{*}{\multicolumn{2}{|c|}{ Type D1, S/N 021, Rt }} & & \multirow{2}{*}{\multicolumn{2}{|c|}{\begin{tabular}{|l|} 
use 1 or 0 to \\
in- or exclude
\end{tabular}}} & choose: & \multirow[b]{3}{*}{$U\left(x_{i}-X_{\text {ref }}\right) / \mu \mathrm{m}$} & \multirow[b]{3}{*}{$E \mathrm{n}$} & \multirow[b]{3}{*}{$w_{i}$} \\
\hline & & & & & & & $k=2$ & & & \\
\hline Institute & $x_{i} / \mu \mathrm{m}$ & $\sigma_{i} / \mu \mathrm{m}$ & $u_{\mathrm{i}} / \mu \mathrm{m}$ & $v_{\text {eff }}$ & on/off & $\left(x_{i}-x_{\mathrm{w}}\right) / \mu \mathrm{m}$ & $k$ & & & \\
\hline METAS & 1.220 & 0.100 & 0.050 & 73 & 1 & 0.065 & 2.00 & 0.098 & 0.66 & 0.03 \\
\hline DTU-CGM & 1.180 & 0.185 & 0.055 & 10000 & 1 & 0.025 & 2.00 & 0.109 & 0.23 & 0.03 \\
\hline MIKES & 1.172 & 0.092 & 0.017 & 11 & 1 & 0.017 & 2.00 & 0.029 & 0.57 & 0.26 \\
\hline $\mathrm{IPQ}$ & 1.170 & 0.104 & 0.109 & 77 & 1 & 0.015 & 2.00 & 0.217 & 0.07 & 0.01 \\
\hline BEV & 0.000 & 0.000 & 0.000 & \#NV & 0 & \#NV & \#NV & \#NV & \#NV & 0.00 \\
\hline SP & 1.151 & 0.017 & 0.018 & 15 & 1 & -0.004 & 2.00 & 0.031 & 0.14 & 0.24 \\
\hline INRIM & 1.207 & 0.123 & 0.125 & 12 & 1 & 0.052 & 2.00 & 0.249 & 0.21 & 0.00 \\
\hline LNE & 1.121 & 0.035 & 0.020 & 62 & 1 & -0.034 & 2.00 & 0.036 & 0.95 & 0.19 \\
\hline CEM & 1.191 & 0.099 & 0.055 & 10000 & 1 & 0.036 & 2.00 & 0.109 & 0.33 & 0.03 \\
\hline GUM & 1.005 & 0.044 & 0.036 & 100 & 0 & -0.150 & 2.00 & 0.074 & 2.03 & 0.00 \\
\hline DMDM & 1.137 & 0.029 & 0.030 & 10000 & 1 & -0.018 & 2.00 & 0.058 & 0.32 & 0.08 \\
\hline UME & 1.163 & 0.150 & 0.036 & 173 & 1 & 0.008 & 2.00 & 0.070 & 0.11 & 0.06 \\
\hline NIMT & 1.093 & 0.063 & 0.057 & 656 & 1 & -0.062 & 2.00 & 0.113 & 0.55 & 0.02 \\
\hline NMC/A*STAR & 1.291 & 0.130 & 0.041 & 10000 & 0 & 0.136 & 2.00 & 0.084 & 1.62 & 0.00 \\
\hline CMS/ITRI & 1.027 & 0.073 & 0.086 & 11 & 1 & -0.128 & 2.00 & 0.171 & 0.75 & 0.01 \\
\hline NMISA & 1.278 & 0.059 & 0.066 & 10000 & 1 & 0.122 & 2.00 & 0.130 & 0.94 & 0.02 \\
\hline \multirow[t]{2}{*}{ INMETRO } & 1.196 & 0.086 & 0.055 & 19 & 1 & 0.040 & 2.00 & 0.108 & 0.38 & 0.03 \\
\hline & $x_{\mathrm{w}}$ & & $u\left(x_{\mathrm{w}}\right)$ & $v_{\text {eff }}$ & $N-1$ & & $\boldsymbol{k}_{\text {ref }}$ & & & \\
\hline Reference value & 1.155 & & 0.009 & 95 & 13 & & 2.00 & & & \\
\hline \multirow[t]{5}{*}{ 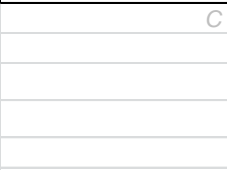 } & $7.63 E-05$ & & & & & & & & & \\
\hline & & & & & & \multicolumn{2}{|c|}{ Consistency: } & & & \\
\hline & & & & & & $u_{\text {ext }}$ & 0.009 & & & \\
\hline & & & & & & $R_{\mathrm{B}}$ & 1.050 & Birge ok & & \\
\hline & & & & & & Limit & 1.336 & & & \\
\hline
\end{tabular}

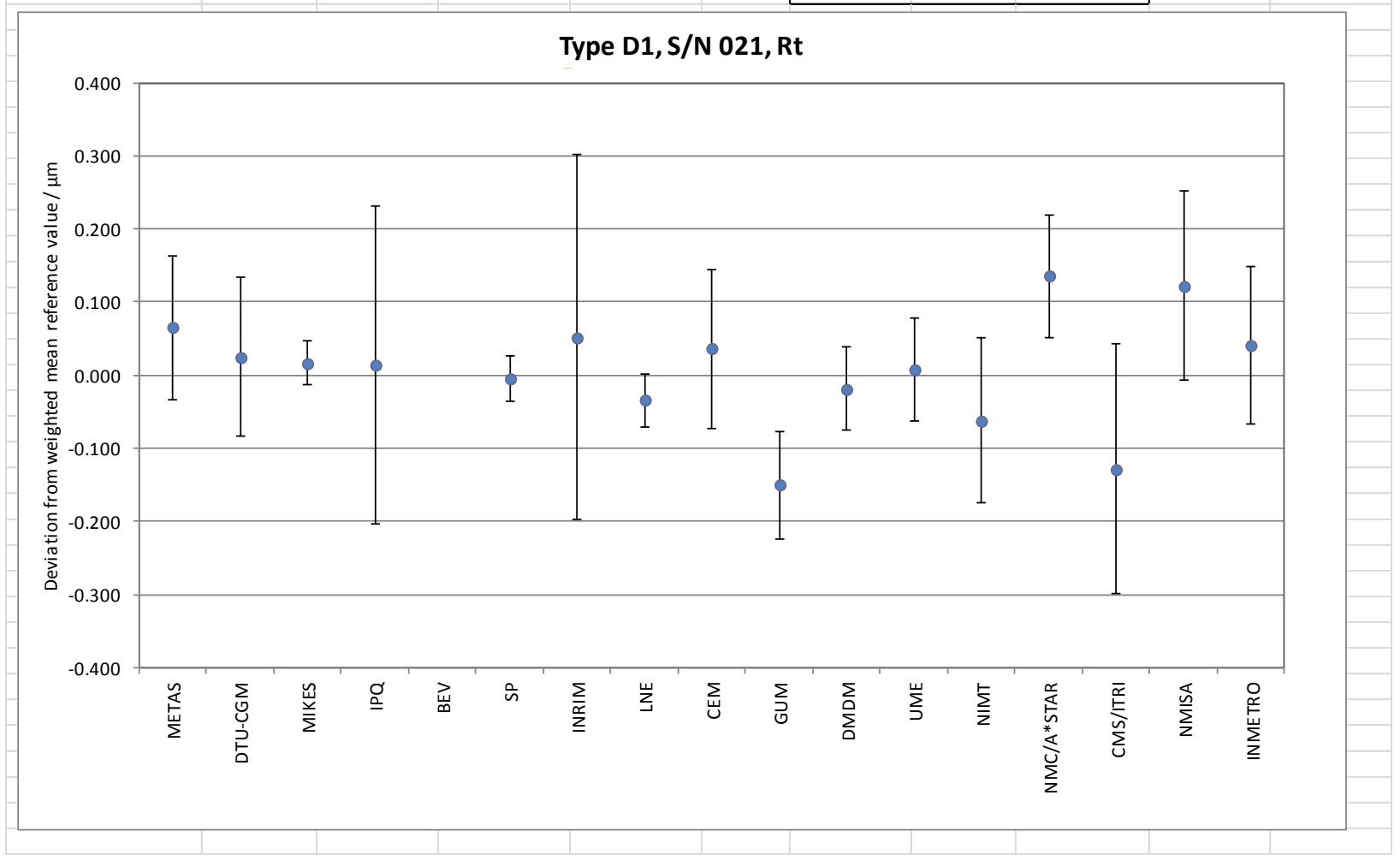




\begin{tabular}{|c|c|c|c|c|c|c|c|c|c|c|}
\hline \multirow{4}{*}{\begin{tabular}{|l|} 
select gauge \\
Institute \\
\end{tabular}} & \multirow{4}{*}{$16 \underset{x_{\mathrm{i}} / \mu \mathrm{m}}{\vec{\nabla}}$} & \multirow{3}{*}{\multicolumn{3}{|c|}{ Type D1, KNT 2070/03, S/N 0986, Ra }} & \multirow{3}{*}{\multicolumn{2}{|c|}{$\begin{array}{l}\text { use } 1 \text { or } 0 \text { to } \\
\text { in- or exclude }\end{array}$}} & \multirow{3}{*}{$\begin{array}{c}\text { choose: } \\
k=2\end{array}$} & \multirow{4}{*}{$U\left(x_{i}-X_{\text {ref }}\right) / \mu \mathrm{m}$} & \multirow[b]{4}{*}{ En } & \\
\hline & & & & & & & & & & \multirow[b]{3}{*}{$w_{i}$} \\
\hline & & & & & & & & & & \\
\hline & & $\sigma_{i} / \mu \mathrm{m}$ & $u_{\mathrm{i}} / \mu \mathrm{m}$ & $v_{\text {eff }}$ & on/off & $\left(x_{i}-x_{\mathrm{w}}\right) / \mu \mathrm{m}$ & $k$ & & & \\
\hline METAS & 0.060 & 0.001 & 0.002 & 147 & 1 & 0.000 & 2.00 & 0.004 & 0.01 & 0.18 \\
\hline DTU-CGM & 0.059 & 0.002 & 0.004 & 10000 & 1 & -0.001 & 2.00 & 0.008 & 0.12 & 0.05 \\
\hline MIKES & 0.061 & 0.001 & 0.005 & 11 & 1 & 0.001 & 2.00 & 0.010 & 0.13 & 0.04 \\
\hline IPQ & 0.060 & 0.001 & 0.030 & 108 & 1 & 0.000 & 2.00 & 0.060 & 0.00 & 0.00 \\
\hline BEV & 0.000 & 0.000 & 0.000 & \#NV & 0 & \#NV & \#NV & \#NV & \#NV & 0.00 \\
\hline SP & 0.060 & 0.001 & 0.004 & 124 & 1 & 0.000 & 2.00 & 0.008 & 0.01 & 0.05 \\
\hline INRIM & 0.060 & 0.002 & 0.004 & 145 & 1 & 0.000 & 2.00 & 0.008 & 0.00 & 0.05 \\
\hline LNE & 0.060 & 0.002 & 0.003 & 31 & 1 & 0.000 & 2.00 & 0.006 & 0.01 & 0.10 \\
\hline CEM & 0.059 & 0.001 & 0.002 & 10000 & 1 & -0.001 & 2.00 & 0.003 & 0.17 & 0.23 \\
\hline GUM & 0.059 & 0.001 & 0.008 & 38 & 1 & -0.001 & 2.00 & 0.016 & 0.06 & 0.01 \\
\hline DMDM & 0.061 & 0.002 & 0.005 & 10000 & 1 & 0.001 & 2.00 & 0.010 & 0.10 & 0.03 \\
\hline UME & 0.061 & 0.002 & 0.005 & 137 & 1 & 0.001 & 2.00 & 0.009 & 0.11 & 0.04 \\
\hline NIMT & 0.060 & 0.001 & 0.008 & 1415523 & 1 & 0.000 & 2.00 & 0.015 & 0.00 & 0.01 \\
\hline $\mathrm{NMC} / \mathrm{A}^{*} \mathrm{STAR}$ & 0.060 & 0.001 & 0.005 & 10000 & 1 & 0.000 & 2.00 & 0.010 & 0.00 & 0.04 \\
\hline CMS/ITRI & 0.060 & 0.001 & 0.003 & 86 & 1 & 0.000 & 2.00 & 0.006 & 0.01 & 0.10 \\
\hline NMISA & 0.062 & 0.002 & 0.006 & 10000 & 1 & 0.002 & 2.00 & 0.011 & 0.18 & 0.03 \\
\hline \multirow[t]{2}{*}{ INMETRO } & 0.061 & 0.002 & 0.006 & 10000 & 1 & 0.001 & 2.00 & 0.012 & 0.08 & 0.02 \\
\hline & $x_{\mathrm{w}}$ & & $u\left(x_{\mathrm{w}}\right)$ & $v_{\text {eff }}$ & $N-1$ & & $\boldsymbol{k}_{\text {ref }}$ & & & \\
\hline \multirow[t]{6}{*}{ Reference value } & 0.060 & & 0.001 & 1211 & 15 & & 2.00 & & & \\
\hline & $8.80 \mathrm{E}-07$ & & & & & & & & & \\
\hline & & & & & & \multicolumn{2}{|c|}{ Consistency: } & & & \\
\hline & & & & & & $u_{\text {ext }}$ & 0.000 & & & \\
\hline & & & & & & $R_{\mathrm{B}}$ & 0.174 & Birge ok & & \\
\hline & & & & & & Limit & 1.315 & & & \\
\hline
\end{tabular}

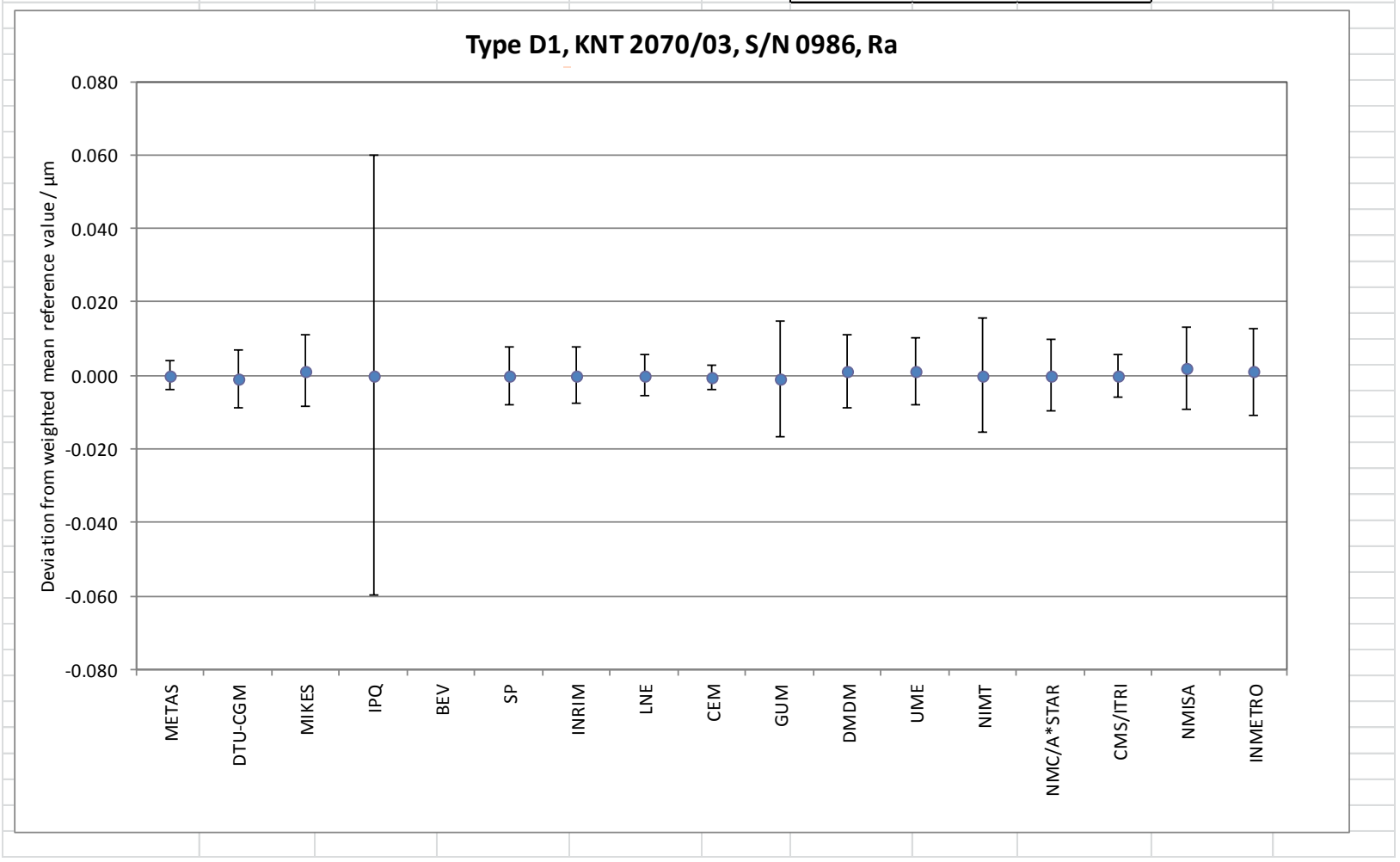




\begin{tabular}{|c|c|c|c|c|c|c|c|c|c|c|}
\hline \multirow[b]{2}{*}{ select gauge } & \multirow[b]{2}{*}{17} & & & & \multirow{2}{*}{\multicolumn{2}{|c|}{$\begin{array}{l}\text { use } 1 \text { or } 0 \text { to } \\
\text { in- or exclude }\end{array}$}} & choose: & \multirow[b]{3}{*}{$U\left(x_{i}-x_{\text {ref }}\right) / \mu \mathrm{m}$} & \multirow[b]{3}{*}{$E \mathrm{n}$} & \multirow[b]{3}{*}{$w_{i}$} \\
\hline & & \multicolumn{3}{|c|}{ Type D1, KNT 2070/03, S/N 0986, Rq } & & & $k=2$ & & & \\
\hline Institute & $x_{\mathrm{i}} / \mu \mathrm{m}$ & $\sigma_{i} / \mu \mathrm{m}$ & $u_{\mathrm{i}} / \mu \mathrm{m}$ & $v_{\text {eff }}$ & on/off & $\left(x_{i}-x_{\mathrm{w}}\right) / \mu \mathrm{m}$ & $k$ & & & \\
\hline METAS & 0.075 & 0.001 & 0.002 & 168 & 1 & 0.000 & 2.00 & 0.004 & 0.09 & 0.19 \\
\hline DTU-CGM & 0.073 & 0.003 & 0.004 & 10000 & 1 & -0.001 & 2.00 & 0.008 & 0.16 & 0.06 \\
\hline MIKES & 0.076 & 0.001 & 0.005 & 11 & 1 & 0.002 & 2.00 & 0.010 & 0.16 & 0.04 \\
\hline IPQ & 0.070 & 0.001 & 0.030 & 108 & 1 & -0.004 & 2.00 & 0.060 & 0.07 & 0.00 \\
\hline BEV & 0.000 & 0.000 & 0.000 & \#NV & 0 & \#NV & \#NV & \#NV & \#NV & 0.00 \\
\hline SP & 0.074 & 0.001 & 0.004 & 126 & 1 & 0.000 & 2.00 & 0.008 & 0.01 & 0.06 \\
\hline INRIM & 0.074 & 0.002 & 0.004 & 149 & 1 & 0.000 & 2.00 & 0.008 & 0.03 & 0.06 \\
\hline LNE & 0.074 & 0.002 & 0.003 & 31 & 1 & 0.000 & 2.00 & 0.006 & 0.04 & 0.11 \\
\hline CEM & 0.073 & 0.001 & 0.002 & 10000 & 1 & -0.001 & 2.00 & 0.004 & 0.23 & 0.17 \\
\hline GUM & 0.073 & 0.001 & 0.008 & 38 & 1 & -0.001 & 2.00 & 0.016 & 0.08 & 0.02 \\
\hline DMDM & 0.076 & 0.002 & 0.005 & 10000 & 1 & 0.002 & 2.00 & 0.010 & 0.17 & 0.04 \\
\hline UME & 0.076 & 0.002 & 0.006 & 137 & 1 & 0.002 & 2.00 & 0.011 & 0.16 & 0.03 \\
\hline NIMT & 0.073 & 0.002 & 0.008 & 1046899 & 1 & -0.001 & 2.00 & 0.016 & 0.08 & 0.02 \\
\hline NMC/A*STAR & 0.075 & 0.001 & 0.005 & 10000 & 1 & 0.001 & 2.00 & 0.010 & 0.08 & 0.04 \\
\hline CMS/ITRI & 0.074 & 0.002 & 0.003 & 62 & 1 & -0.001 & 2.00 & 0.006 & 0.10 & 0.10 \\
\hline NMISA & 0.077 & 0.002 & 0.006 & 10000 & 1 & 0.002 & 2.00 & 0.011 & 0.21 & 0.03 \\
\hline \multirow[t]{2}{*}{ INMETRO } & 0.076 & 0.002 & 0.006 & 10000 & 1 & 0.001 & 2.00 & 0.012 & 0.11 & 0.03 \\
\hline & $x_{\mathrm{w}}$ & & $u\left(x_{w}\right)$ & $v_{\text {eff }}$ & $N-1$ & & $\boldsymbol{k}_{\text {ref }}$ & & & \\
\hline Reference value & 0.074 & & 0.001 & 1018 & 15 & & 2.00 & & & \\
\hline \multirow[t]{5}{*}{$C$} & 1.00E-06 & & & & & & & & & \\
\hline & & & & & & \multicolumn{2}{|c|}{ Consistency: } & & & \\
\hline & & & & & & $u_{\text {ext }}$ & 0.000 & & & \\
\hline & & & & & & $R_{\mathrm{B}}$ & 0.255 & Birge ok & & \\
\hline & & & & & & Limit & 1.315 & & & \\
\hline
\end{tabular}

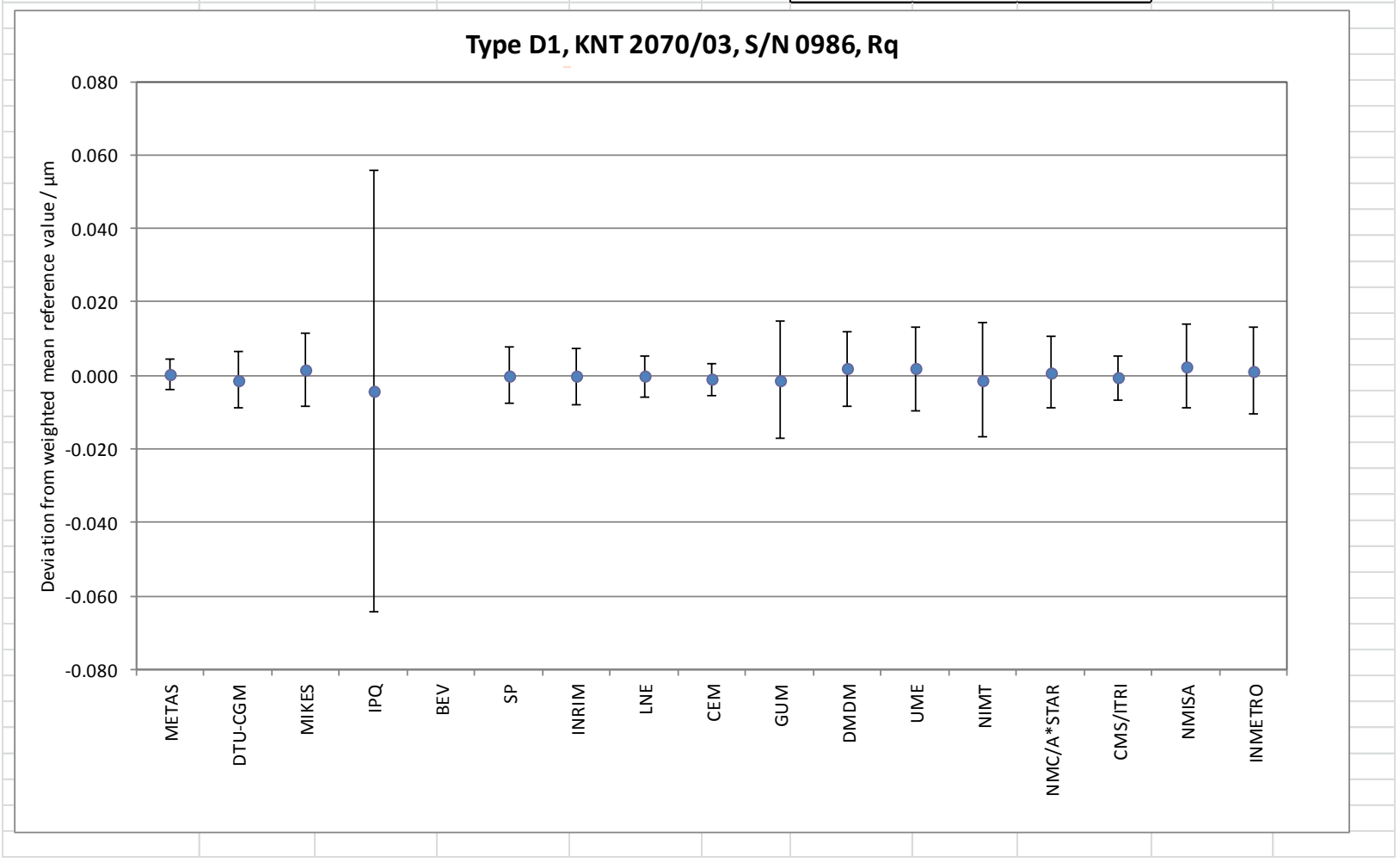




\begin{tabular}{|c|c|c|c|c|c|c|c|c|c|c|}
\hline \multirow[b]{2}{*}{ select gauge } & \multirow[b]{2}{*}{18} & \multirow{2}{*}{\multicolumn{3}{|c|}{ Type D1, KNT 2070/03, S/N 0986, Rz }} & \multirow{2}{*}{\multicolumn{2}{|c|}{$\begin{array}{l}\text { use } 1 \text { or } 0 \text { to } \\
\text { in- or exclude }\end{array}$}} & \multirow{2}{*}{$\begin{array}{c}\text { choose: } \\
k=2\end{array}$} & \multirow[b]{3}{*}{$U\left(x_{i}-x_{\text {ref }}\right) / \mu \mathrm{m}$} & \multirow[b]{3}{*}{$E \mathrm{n}$} & \multirow[b]{3}{*}{$w_{i}$} \\
\hline & & & & & & & & & & \\
\hline Institute & $x_{\mathrm{i}} / \mu \mathrm{m}$ & $\sigma_{i} / \mu \mathrm{m}$ & $u_{i} / \mu \mathrm{m}$ & $v_{\text {eff }}$ & on/off & $\left(x_{i}-x_{\mathrm{w}}\right) / \mu \mathrm{m}$ & $k$ & & & \\
\hline METAS & 0.326 & 0.003 & 0.021 & 157 & 1 & -0.001 & 2.00 & 0.042 & 0.03 & 0.01 \\
\hline DTU-CGM & 0.323 & 0.013 & 0.011 & 10000 & 1 & -0.004 & 2.00 & 0.021 & 0.19 & 0.05 \\
\hline MIKES & 0.347 & 0.005 & 0.013 & 11 & 1 & 0.020 & 2.00 & 0.026 & 0.76 & 0.04 \\
\hline IPQ & 0.330 & 0.008 & 0.031 & 122 & 1 & 0.003 & 2.00 & 0.062 & 0.05 & 0.01 \\
\hline BEV & 0.000 & 0.000 & 0.000 & \#NV & 0 & \#NV & \#NV & \#NV & \#NV & 0.00 \\
\hline SP & 0.324 & 0.003 & 0.005 & 97 & 1 & -0.003 & 2.00 & 0.009 & 0.31 & 0.24 \\
\hline INRIM & 0.328 & 0.009 & 0.009 & 25 & 1 & 0.001 & 2.00 & 0.017 & 0.05 & 0.07 \\
\hline LNE & 0.323 & 0.011 & 0.010 & 59 & 1 & -0.004 & 2.00 & 0.019 & 0.21 & 0.06 \\
\hline CEM & 0.325 & 0.007 & 0.005 & 10000 & 1 & -0.002 & 2.00 & 0.008 & 0.26 & 0.27 \\
\hline GUM & 0.313 & 0.004 & 0.022 & 16 & 1 & -0.014 & 2.00 & 0.044 & 0.32 & 0.01 \\
\hline DMDM & 0.335 & 0.010 & 0.013 & 10000 & 1 & 0.008 & 2.00 & 0.026 & 0.31 & 0.04 \\
\hline UME & 0.329 & 0.010 & 0.025 & 137 & 1 & 0.002 & 2.00 & 0.050 & 0.04 & 0.01 \\
\hline NIMT & 0.325 & 0.012 & 0.022 & 19484 & 1 & -0.002 & 2.00 & 0.044 & 0.05 & 0.01 \\
\hline NMC/A*STAR & 0.329 & 0.011 & 0.014 & 10000 & 1 & 0.002 & 2.00 & 0.028 & 0.07 & 0.03 \\
\hline CMS/ITRI & 0.323 & 0.007 & 0.013 & 66 & 1 & -0.004 & 2.00 & 0.026 & 0.15 & 0.04 \\
\hline NMISA & 0.335 & 0.006 & 0.012 & 10000 & 1 & 0.008 & 2.00 & 0.024 & 0.32 & 0.04 \\
\hline \multirow[t]{2}{*}{ INMETRO } & 0.334 & 0.018 & 0.009 & 10000 & 1 & 0.007 & 2.00 & 0.016 & 0.43 & 0.08 \\
\hline & $x_{\mathrm{w}}$ & & $u\left(x_{\mathrm{w}}\right)$ & $v_{\text {eff }}$ & $N-1$ & & $\boldsymbol{k}_{\text {ref }}$ & & & \\
\hline Reference value & 0.327 & & 0.002 & 1000 & 15 & & 2.00 & & & \\
\hline \multirow[t]{5}{*}{ 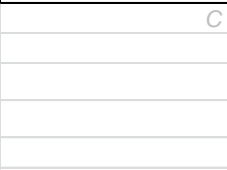 } & 5.92E-06 & & & & & & & & & \\
\hline & & & & & & \multicolumn{2}{|c|}{ Consistency: } & & & \\
\hline & & & & & & $u_{\text {ext }}$ & 0.001 & & & \\
\hline & & & & & & $R_{\mathrm{B}}$ & 0.578 & Birge ok & & \\
\hline & & & & & & Limit & 1.315 & & & \\
\hline
\end{tabular}

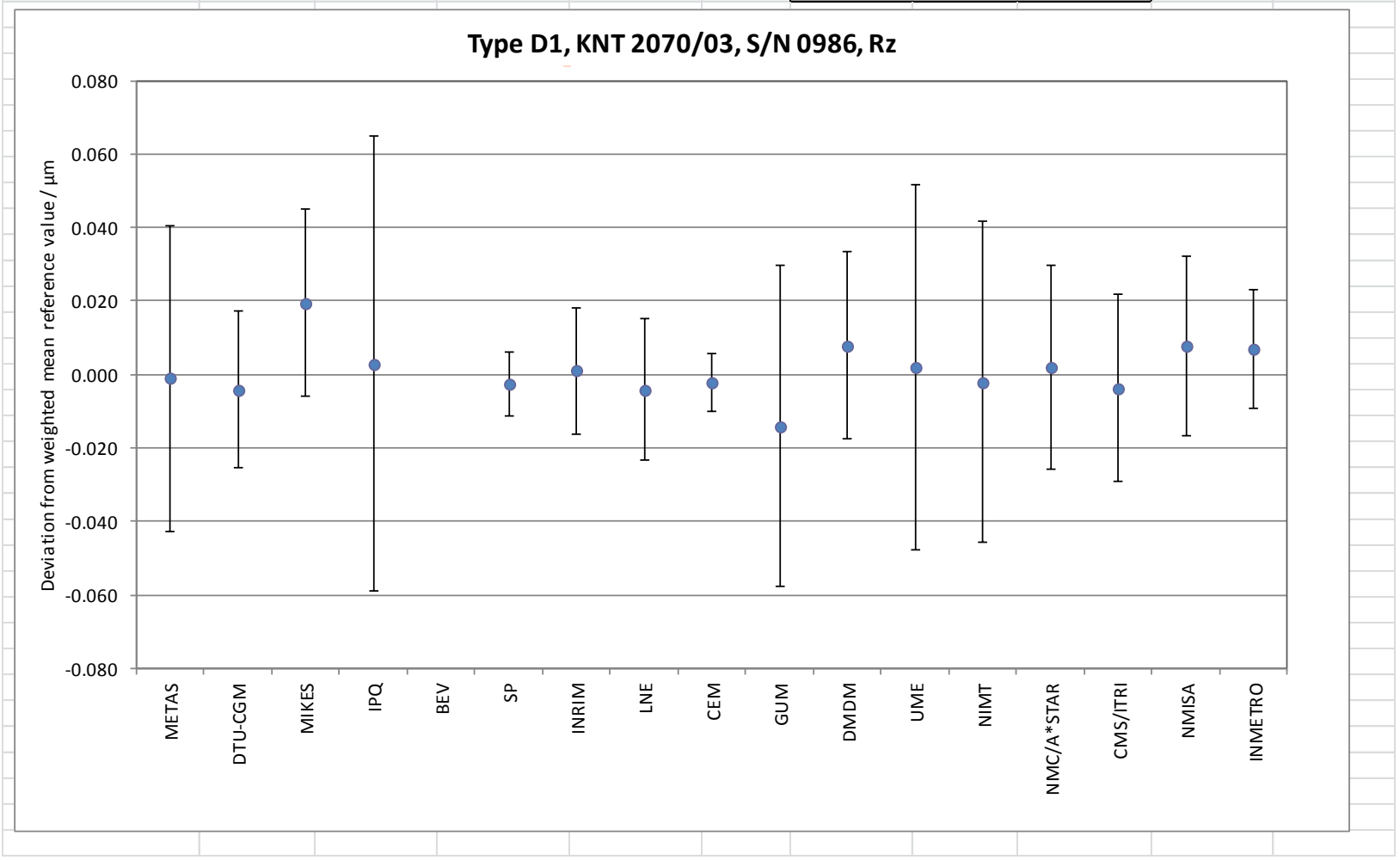




\begin{tabular}{|c|c|c|c|c|c|c|c|c|c|c|}
\hline \multirow[b]{2}{*}{ select gauge } & \multirow[b]{2}{*}{19} & \multirow{2}{*}{\multicolumn{3}{|c|}{ Type D1, KNT 2070/03, S/N 0986, Rt }} & \multirow{2}{*}{\multicolumn{2}{|c|}{$\begin{array}{l}\text { use } 1 \text { or } 0 \text { to } \\
\text { in- or exclude }\end{array}$}} & \multirow{2}{*}{$\begin{array}{c}\text { choose: } \\
k=2\end{array}$} & \multirow[b]{3}{*}{$U\left(x_{i}-x_{\text {ref }}\right) / \mu \mathrm{m}$} & \multirow[b]{3}{*}{$E \mathrm{n}$} & \multirow[b]{3}{*}{$w_{i}$} \\
\hline & & & & & & & & & & \\
\hline Institute & $x_{\mathrm{i}} / \mu \mathrm{m}$ & $\sigma_{i} / \mu \mathrm{m}$ & $u_{i} / \mu \mathrm{m}$ & $v_{\text {eff }}$ & on/off & $\left(x_{i}-x_{\mathrm{w}}\right) / \mu \mathrm{m}$ & $k$ & & & \\
\hline METAS & 0.442 & 0.015 & 0.023 & 197 & 1 & -0.002 & 2.00 & 0.046 & 0.04 & 0.02 \\
\hline DTU-CGM & 0.446 & 0.012 & 0.010 & 10000 & 1 & 0.002 & 2.00 & 0.019 & 0.12 & 0.09 \\
\hline MIKES & 0.458 & 0.010 & 0.013 & 11 & 1 & 0.014 & 2.00 & 0.026 & 0.54 & 0.05 \\
\hline IPQ & 0.440 & 0.012 & 0.033 & 138 & 1 & -0.004 & 2.00 & 0.066 & 0.06 & 0.01 \\
\hline BEV & 0.000 & 0.000 & 0.000 & \#NV & 0 & \#NV & \#NV & \#NV & \#NV & 0.00 \\
\hline SP & 0.439 & 0.003 & 0.005 & 114 & 1 & -0.005 & 2.00 & 0.008 & 0.61 & 0.36 \\
\hline INRIM & 0.449 & 0.012 & 0.010 & 30 & 1 & 0.005 & 2.00 & 0.019 & 0.28 & 0.09 \\
\hline LNE & 0.435 & 0.016 & 0.017 & 54 & 1 & -0.009 & 2.00 & 0.033 & 0.26 & 0.03 \\
\hline CEM & 0.447 & 0.011 & 0.007 & 10000 & 1 & 0.003 & 2.00 & 0.012 & 0.27 & 0.19 \\
\hline GUM & 0.407 & 0.006 & 0.024 & 19 & 1 & -0.037 & 2.00 & 0.048 & 0.77 & 0.02 \\
\hline DMDM & 0.450 & 0.016 & 0.015 & 10000 & 1 & 0.006 & 2.00 & 0.030 & 0.21 & 0.04 \\
\hline UME & 0.441 & 0.012 & 0.033 & 137 & 1 & -0.003 & 2.00 & 0.067 & 0.04 & 0.01 \\
\hline NIMT & 0.443 & 0.018 & 0.025 & 5442 & 1 & -0.001 & 2.00 & 0.050 & 0.01 & 0.01 \\
\hline NMC/A*STAR & 0.450 & 0.023 & 0.015 & 10000 & 1 & 0.006 & 2.00 & 0.029 & 0.21 & 0.04 \\
\hline CMS/ITRI & 0.443 & 0.017 & 0.023 & 17 & 1 & -0.001 & 2.00 & 0.046 & 0.01 & 0.02 \\
\hline NMISA & 0.450 & 0.020 & 0.024 & 10000 & 1 & 0.006 & 2.00 & 0.047 & 0.13 & 0.02 \\
\hline \multirow[t]{2}{*}{ INMETRO } & 0.455 & 0.032 & 0.037 & 10000 & 1 & 0.011 & 2.00 & 0.073 & 0.16 & 0.01 \\
\hline & $x_{\mathrm{w}}$ & & $u\left(x_{\mathrm{w}}\right)$ & $v_{\text {eff }}$ & $N-1$ & & $\boldsymbol{k}_{\text {ref }}$ & & & \\
\hline Reference value & 0.444 & & 0.003 & 582 & 15 & & 2.00 & & & \\
\hline \multirow[t]{5}{*}{ 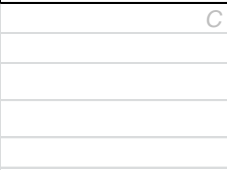 } & 9.06E-06 & & & & & & & & & \\
\hline & & & & & & \multicolumn{2}{|c|}{ Consistency: } & & & \\
\hline & & & & & & $u_{\text {ext }}$ & 0.002 & & & \\
\hline & & & & & & $R_{\mathrm{B}}$ & 0.621 & Birge ok & & \\
\hline & & & & & & Limit & 1.315 & & & \\
\hline
\end{tabular}

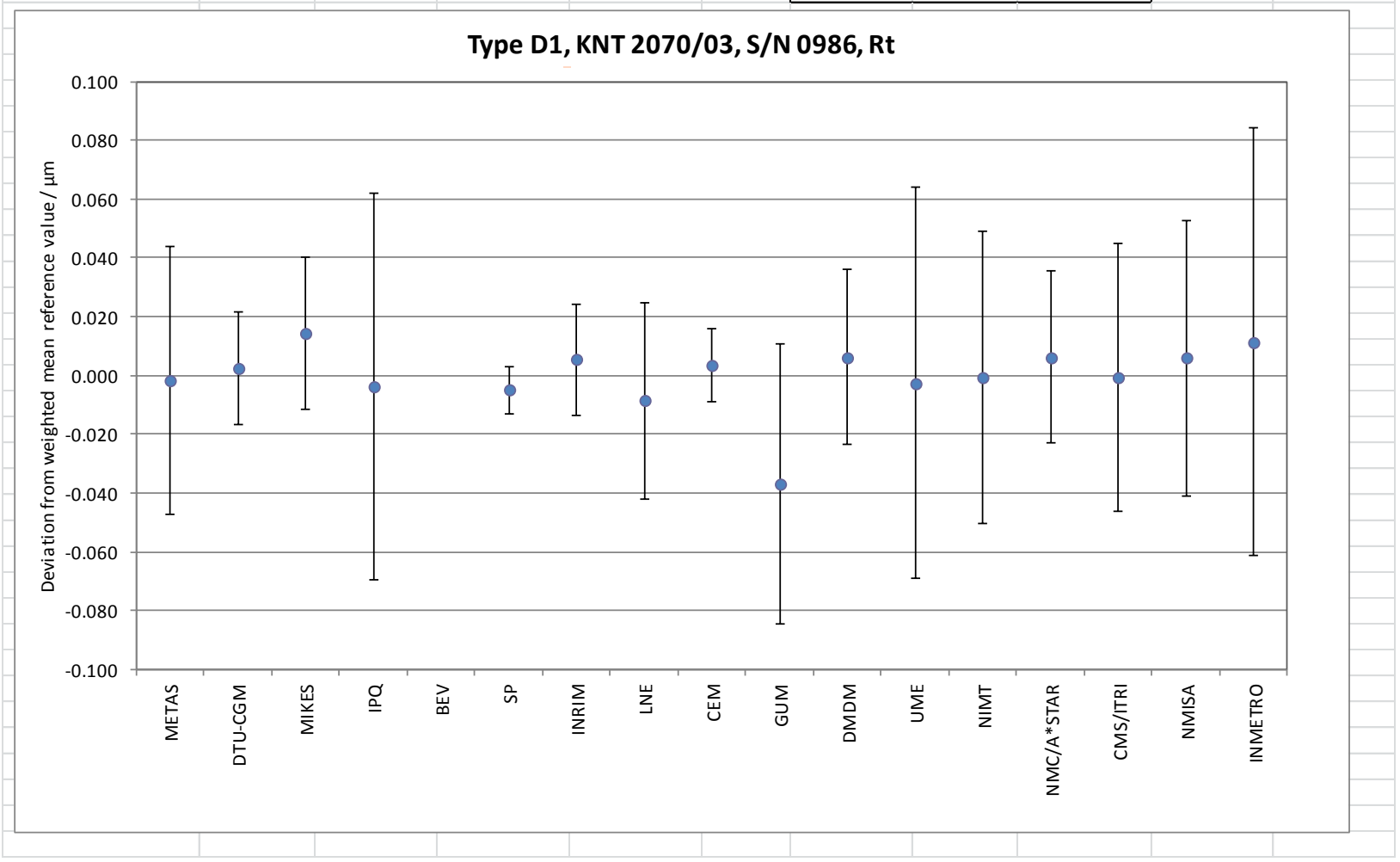




\begin{tabular}{|c|c|c|c|c|c|c|c|c|c|c|}
\hline \multirow[b]{2}{*}{ select gauge } & \multirow[b]{2}{*}{20} & \multirow{2}{*}{\multicolumn{3}{|c|}{ Type C1, NIST SRM 2072, S/N 1015, Ra }} & \multirow{2}{*}{\multicolumn{2}{|c|}{$\begin{array}{l}\text { use } 1 \text { or } 0 \text { to } \\
\text { in- or exclude }\end{array}$}} & \multirow{2}{*}{$\begin{array}{c}\text { choose: } \\
k=2\end{array}$} & \multirow[b]{3}{*}{$U\left(x_{i}-x_{\text {ref }}\right) / \mu \mathrm{m}$} & \multirow[b]{3}{*}{$E \mathrm{n}$} & \multirow[b]{3}{*}{$w_{i}$} \\
\hline & & & & & & & & & & \\
\hline Institute & $x_{\mathrm{i}} / \mu \mathrm{m}$ & $\sigma_{i} / \mu \mathrm{m}$ & $u_{\mathrm{i}} / \mu \mathrm{m}$ & $v_{\text {eff }}$ & on/off & $\left(x_{i}-x_{\mathrm{w}}\right) / \mu \mathrm{m}$ & $k$ & & & \\
\hline METAS & 1.010 & 0.003 & 0.010 & 180 & 1 & 0.001 & 2.00 & 0.020 & 0.04 & 0.04 \\
\hline DTU-CGM & 1.008 & 0.005 & 0.005 & 10000 & 1 & -0.001 & 2.00 & 0.009 & 0.13 & 0.18 \\
\hline MIKES & 1.014 & 0.004 & 0.011 & 11 & 1 & 0.005 & 2.00 & 0.022 & 0.24 & 0.03 \\
\hline IPQ & 1.000 & 0.001 & 0.035 & 74 & 1 & -0.009 & 2.00 & 0.070 & 0.13 & 0.00 \\
\hline BEV & 0.000 & 0.000 & 0.000 & \#NV & 0 & \#NV & \#NV & \#NV & \#NV & 0.00 \\
\hline SP & 1.011 & 0.001 & 0.006 & 225 & 1 & 0.002 & 2.00 & 0.011 & 0.16 & 0.12 \\
\hline INRIM & 1.012 & 0.003 & 0.011 & 68 & 1 & 0.003 & 2.00 & 0.022 & 0.13 & 0.04 \\
\hline LNE & 1.009 & 0.003 & 0.007 & 23 & 1 & 0.000 & 2.00 & 0.013 & 0.01 & 0.09 \\
\hline CEM & 1.010 & 0.002 & 0.004 & 10000 & 1 & 0.001 & 2.00 & 0.008 & 0.11 & 0.23 \\
\hline GUM & 1.004 & 0.001 & 0.015 & 40 & 1 & -0.005 & 2.00 & 0.030 & 0.17 & 0.02 \\
\hline DMDM & 1.016 & 0.002 & 0.016 & 10000 & 1 & 0.007 & 2.00 & 0.032 & 0.22 & 0.02 \\
\hline UME & 1.009 & 0.005 & 0.011 & 265 & 1 & 0.000 & 2.00 & 0.022 & 0.01 & 0.03 \\
\hline NIMT & 1.001 & 0.002 & 0.011 & 363696 & 1 & -0.008 & 2.00 & 0.022 & 0.38 & 0.04 \\
\hline NMC/A*STAR & 1.010 & 0.002 & 0.010 & 10000 & 1 & 0.001 & 2.00 & 0.020 & 0.04 & 0.04 \\
\hline CMS/ITRI & 1.006 & 0.002 & 0.007 & 136 & 1 & -0.003 & 2.00 & 0.014 & 0.20 & 0.08 \\
\hline NMISA & 1.009 & 0.003 & 0.024 & 10000 & 1 & 0.000 & 2.00 & 0.048 & 0.00 & 0.01 \\
\hline \multirow[t]{2}{*}{ INMETRO } & 1.009 & 0.001 & 0.015 & 10000 & 1 & 0.000 & 2.00 & 0.030 & 0.00 & 0.02 \\
\hline & $x_{\mathrm{w}}$ & & $u\left(x_{\mathrm{w}}\right)$ & $v_{\text {eff }}$ & $N-1$ & & $\boldsymbol{k}_{\text {ref }}$ & & & \\
\hline Reference value & 1.009 & & 0.002 & 1574 & 15 & & 2.00 & & & \\
\hline \multirow[t]{5}{*}{$C$} & $4.43 E-06$ & & & & & & & & & \\
\hline & & & & & & \multicolumn{2}{|c|}{ Consistency: } & & & \\
\hline & & & & & & $u_{\text {ext }}$ & 0.001 & & & \\
\hline & & & & & & $R_{\mathrm{B}}$ & 0.322 & Birge ok & & \\
\hline & & & & & & Limit & 1.315 & & & \\
\hline
\end{tabular}

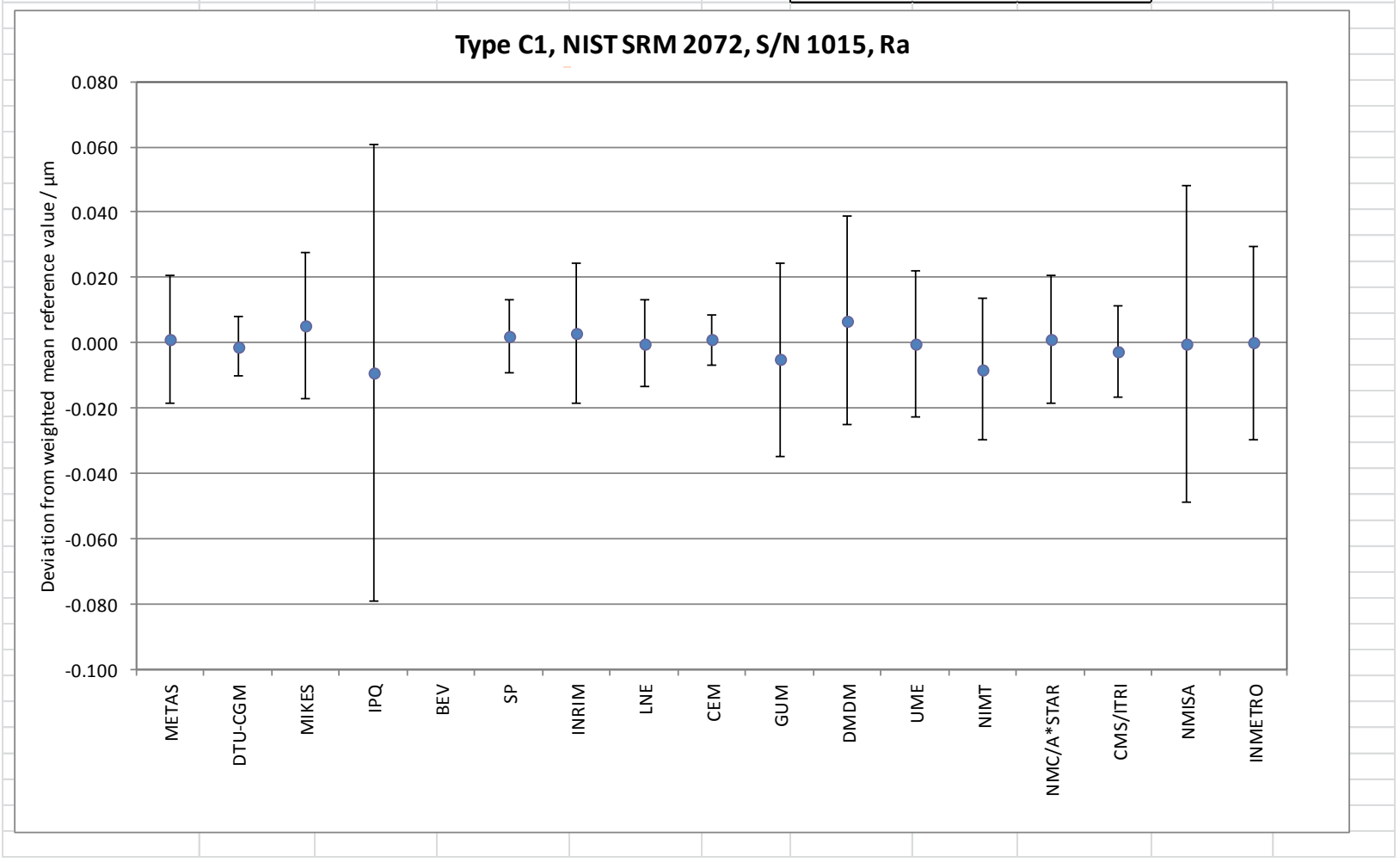




\begin{tabular}{|c|c|c|c|c|c|c|c|c|c|c|}
\hline \multirow[b]{2}{*}{ select gauge } & & \multirow{2}{*}{\multicolumn{3}{|c|}{ Type C1, NIST SRM 2072, S/N 1015, Rq }} & \multirow{2}{*}{\multicolumn{2}{|c|}{$\begin{array}{l}\text { use } 1 \text { or } 0 \text { to } \\
\text { in- or exclude }\end{array}$}} & choose: & \multirow[b]{3}{*}{$U\left(x_{i}-x_{\text {ref }}\right) / \mu \mathrm{m}$} & \multirow[b]{3}{*}{$E \mathrm{n}$} & \multirow[b]{3}{*}{$w_{i}$} \\
\hline & 21 & & & & & & $k=2$ & & & \\
\hline Institute & $x_{\mathrm{i}} / \mu \mathrm{m}$ & $\sigma_{i} / \mu \mathrm{m}$ & $u_{\mathrm{i}} / \mu \mathrm{m}$ & $v_{\text {eff }}$ & on/off & $\left(x_{i}-x_{\mathrm{w}}\right) / \mu \mathrm{m}$ & $k$ & & & \\
\hline METAS & 1.120 & 0.003 & 0.011 & 178 & 1 & 0.001 & 2.00 & 0.022 & 0.07 & 0.04 \\
\hline DTU-CGM & 1.118 & 0.005 & 0.005 & 10000 & 1 & -0.001 & 2.00 & 0.009 & 0.06 & 0.21 \\
\hline MIKES & 1.124 & 0.004 & 0.012 & 11 & 1 & 0.006 & 2.00 & 0.024 & 0.24 & 0.03 \\
\hline $\mathrm{IPQ}$ & 1.110 & 0.001 & 0.035 & 74 & 1 & -0.009 & 2.00 & 0.070 & 0.12 & 0.00 \\
\hline BEV & 0.000 & 0.000 & 0.000 & \#NV & 0 & \#NV & \#NV & \#NV & \#NV & 0.00 \\
\hline $\mathrm{SP}$ & 1.120 & 0.001 & 0.007 & 210 & 1 & 0.001 & 2.00 & 0.013 & 0.11 & 0.11 \\
\hline INRIM & 1.123 & 0.003 & 0.012 & 65 & 1 & 0.004 & 2.00 & 0.024 & 0.19 & 0.04 \\
\hline LNE & 1.119 & 0.004 & 0.008 & 22 & 1 & 0.000 & 2.00 & 0.015 & 0.03 & 0.08 \\
\hline CEM & 1.120 & 0.003 & 0.005 & 10000 & 1 & 0.001 & 2.00 & 0.008 & 0.17 & 0.23 \\
\hline GUM & 1.113 & 0.001 & 0.016 & 34 & 1 & -0.006 & 2.00 & 0.032 & 0.18 & 0.02 \\
\hline DMDM & 1.126 & 0.002 & 0.018 & 10000 & 1 & 0.007 & 2.00 & 0.035 & 0.21 & 0.02 \\
\hline UME & 1.119 & 0.005 & 0.013 & 265 & 1 & 0.000 & 2.00 & 0.025 & 0.02 & 0.03 \\
\hline NIMT & 1.100 & 0.008 & 0.012 & 4398 & 1 & -0.019 & 2.00 & 0.023 & 0.79 & 0.04 \\
\hline NMC/A*STAR & 1.120 & 0.003 & 0.011 & 10000 & 1 & 0.001 & 2.00 & 0.022 & 0.07 & 0.04 \\
\hline CMS/ITRI & 1.116 & 0.003 & 0.008 & 130 & 1 & -0.002 & 2.00 & 0.015 & 0.16 & 0.08 \\
\hline NMISA & 1.119 & 0.003 & 0.027 & 10000 & 1 & 0.000 & 2.00 & 0.053 & 0.01 & 0.01 \\
\hline \multirow[t]{2}{*}{ INMETRO } & 1.119 & 0.002 & 0.016 & 10000 & 1 & 0.001 & 2.00 & 0.032 & 0.02 & 0.02 \\
\hline & $x_{\mathrm{w}}$ & & $u\left(x_{w}\right)$ & $v_{\text {eff }}$ & $N-1$ & & $\boldsymbol{k}_{\text {ref }}$ & & & \\
\hline Reference value & 1.119 & & 0.002 & 1749 & 15 & & 2.00 & & & \\
\hline \multirow[t]{5}{*}{$C$} & $5.21 E-06$ & & & & & & & & & \\
\hline & & & & & & \multicolumn{2}{|c|}{ Consistency: } & & & \\
\hline & & & & & & $u_{\text {ext }}$ & 0.001 & & & \\
\hline & & & & & & $R_{\mathrm{B}}$ & 0.478 & Birge ok & & \\
\hline & & & & & & Limit & 1.315 & & & \\
\hline
\end{tabular}

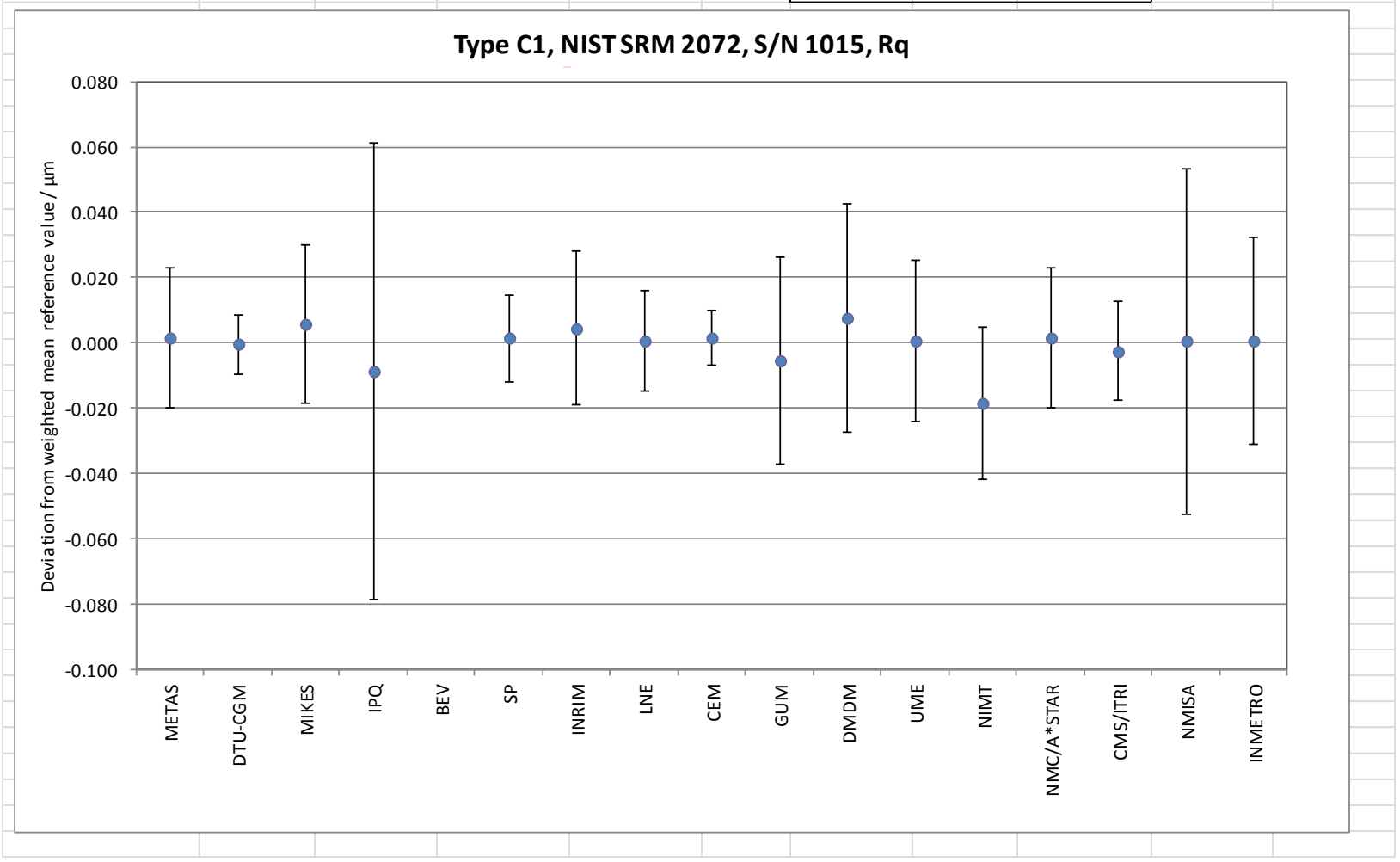




\begin{tabular}{|c|c|c|c|c|c|c|c|c|c|c|}
\hline \multirow[b]{2}{*}{ select gauge } & \multirow[b]{2}{*}{22} & \multirow{2}{*}{\multicolumn{3}{|c|}{ Type C1, NIST SRM 2072, S/N 1015, Rz }} & \multirow{2}{*}{\multicolumn{2}{|c|}{\begin{tabular}{|l|} 
use 1 or 0 to \\
in- or exclude
\end{tabular}}} & \multirow{2}{*}{$\begin{array}{c}\text { choose: } \\
k=2\end{array}$} & \multirow[b]{3}{*}{$U\left(x_{i}-x_{\text {ref }}\right) / \mu \mathrm{m}$} & \multirow[b]{3}{*}{$E \mathrm{n}$} & \multirow[b]{3}{*}{$w_{i}$} \\
\hline & & & & & & & & & & \\
\hline Institute & $x_{\mathrm{i}} / \mu \mathrm{m}$ & $\sigma_{i} / \mu m$ & $u_{\mathrm{i}} / \mu \mathrm{m}$ & $v_{\text {eff }}$ & on/off & $\left(x_{i}-x_{\mathrm{w}}\right) / \mu \mathrm{m}$ & $k$ & & & \\
\hline METAS & 3.350 & 0.010 & 0.090 & 117 & 1 & -0.004 & 2.00 & 0.180 & 0.02 & 0.00 \\
\hline DTU-CGM & 3.371 & 0.014 & 0.013 & 10000 & 1 & 0.017 & 2.00 & 0.023 & 0.74 & 0.23 \\
\hline MIKES & 3.368 & 0.014 & 0.036 & 11 & 1 & 0.014 & 2.00 & 0.071 & 0.20 & 0.03 \\
\hline $\mathrm{IPQ}$ & 3.350 & 0.004 & 0.035 & 76 & 1 & -0.004 & 2.00 & 0.069 & 0.06 & 0.03 \\
\hline BEV & 0.000 & 0.000 & 0.000 & \#NV & 0 & \#NV & \#NV & \#NV & \#NV & 0.00 \\
\hline SP & 3.300 & 0.005 & 0.017 & 130 & 1 & -0.054 & 2.00 & 0.032 & 1.71 & 0.13 \\
\hline INRIM & 3.393 & 0.015 & 0.037 & 61 & 1 & 0.039 & 2.00 & 0.073 & 0.53 & 0.03 \\
\hline LNE & 3.375 & 0.020 & 0.014 & 28 & 1 & 0.021 & 2.00 & 0.025 & 0.83 & 0.19 \\
\hline CEM & 3.359 & 0.014 & 0.015 & 10000 & 1 & 0.005 & 2.00 & 0.026 & 0.18 & 0.18 \\
\hline GUM & 3.314 & 0.005 & 0.046 & 13 & 1 & -0.040 & 2.00 & 0.091 & 0.44 & 0.02 \\
\hline DMDM & 3.378 & 0.012 & 0.068 & 10000 & 1 & 0.024 & 2.00 & 0.136 & 0.18 & 0.01 \\
\hline UME & 3.380 & 0.051 & 0.038 & 265 & 1 & 0.026 & 2.00 & 0.076 & 0.34 & 0.03 \\
\hline NIMT & 3.318 & 0.016 & 0.040 & 32142 & 1 & -0.036 & 2.00 & 0.079 & 0.46 & 0.02 \\
\hline NMC/A*STAR & 3.328 & 0.014 & 0.038 & 15 & 1 & -0.026 & 2.00 & 0.075 & 0.35 & 0.03 \\
\hline $\mathrm{CMS} / \mathrm{ITRI}$ & 3.320 & 0.019 & 0.032 & 43 & 1 & -0.034 & 2.00 & 0.063 & 0.54 & 0.04 \\
\hline NMISA & 3.353 & 0.016 & 0.073 & 10000 & 1 & -0.001 & 2.00 & 0.145 & 0.01 & 0.01 \\
\hline \multirow[t]{2}{*}{ INMETRO } & 3.345 & 0.007 & 0.039 & 10000 & 1 & -0.009 & 2.00 & 0.076 & 0.12 & 0.03 \\
\hline & $x_{\mathrm{w}}$ & & $u\left(x_{\mathrm{w}}\right)$ & $v_{\text {eff }}$ & $N-1$ & & $\boldsymbol{k}_{\text {ref }}$ & & & \\
\hline Reference value & 3.354 & & 0.006 & 585 & 15 & & 2.00 & & & \\
\hline \multirow[t]{5}{*}{ 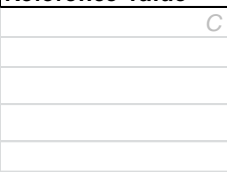 } & $3.82 E-05$ & & & & & & & & & \\
\hline & & & & & & \multicolumn{2}{|c|}{ Consistency: } & & & \\
\hline & & & & & & $u_{\text {ext }}$ & 0.007 & & & \\
\hline & & & & & & $R_{\mathrm{B}}$ & 1.133 & Birge ok & & \\
\hline & & & & & & Limit & 1.315 & & & \\
\hline
\end{tabular}

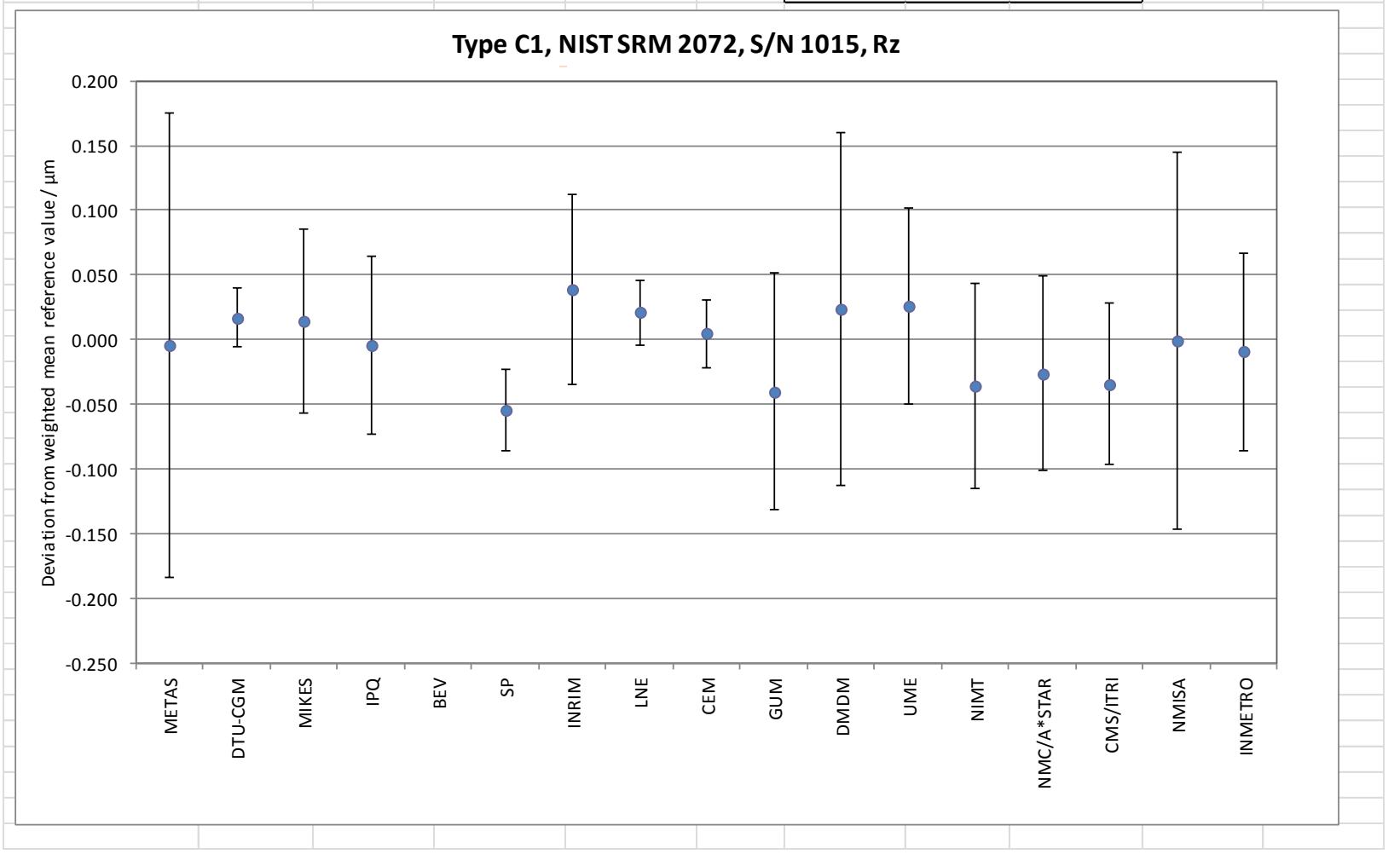




\begin{tabular}{|c|c|c|c|c|c|c|c|c|c|c|}
\hline \multirow[b]{2}{*}{ select gauge } & \multirow[b]{2}{*}{23} & \multirow{2}{*}{\multicolumn{3}{|c|}{ Type C1, NIST SRM 2072, S/N 1015, Rt }} & \multirow{2}{*}{\multicolumn{2}{|c|}{$\begin{array}{l}\text { use } 1 \text { or } 0 \text { to } \\
\text { in- or exclude }\end{array}$}} & \multirow{2}{*}{$\begin{array}{c}\text { choose: } \\
k=2\end{array}$} & \multirow[b]{3}{*}{$U\left(x_{i}-x_{\text {ref }}\right) / \mu \mathrm{m}$} & \multirow[b]{3}{*}{ En } & \multirow[b]{3}{*}{$w_{i}$} \\
\hline & & & & & & & & & & \\
\hline Institute & $x_{\mathrm{i}} / \mu \mathrm{m}$ & $\sigma_{i} / \mu \mathrm{m}$ & $u_{\mathrm{i}} / \mu \mathrm{m}$ & $v_{\text {eff }}$ & on/off & $\left(x_{i}-x_{\mathrm{w}}\right) / \mu \mathrm{m}$ & $k$ & & & \\
\hline METAS & 3.370 & 0.010 & 0.090 & 117 & 1 & -0.011 & 2.00 & 0.179 & 0.06 & 0.01 \\
\hline DTU-CGM & 3.399 & 0.018 & 0.014 & 10000 & 1 & 0.018 & 2.00 & 0.025 & 0.74 & 0.23 \\
\hline MIKES & 3.401 & 0.022 & 0.036 & 11 & 1 & 0.021 & 2.00 & 0.071 & 0.29 & 0.03 \\
\hline IPQ & 3.380 & 0.005 & 0.035 & 77 & 1 & -0.001 & 2.00 & 0.069 & 0.01 & 0.04 \\
\hline BEV & 0.000 & 0.000 & 0.000 & \#NV & 0 & \#NV & \#NV & \#NV & \#NV & 0.00 \\
\hline SP & 3.319 & 0.005 & 0.017 & 130 & 1 & -0.062 & 2.00 & 0.031 & 1.98 & 0.16 \\
\hline INRIM & 3.438 & 0.021 & 0.038 & 63 & 1 & 0.057 & 2.00 & 0.075 & 0.76 & 0.03 \\
\hline LNE & 3.408 & 0.024 & 0.016 & 37 & 1 & 0.027 & 2.00 & 0.029 & 0.94 & 0.18 \\
\hline CEM & 3.376 & 0.012 & 0.017 & 10000 & 1 & -0.005 & 2.00 & 0.031 & 0.15 & 0.16 \\
\hline GUM & 3.336 & 0.007 & 0.047 & 13 & 1 & -0.045 & 2.00 & 0.093 & 0.48 & 0.02 \\
\hline DMDM & 3.405 & 0.018 & 0.069 & 10000 & 1 & 0.024 & 2.00 & 0.137 & 0.18 & 0.01 \\
\hline UME & 3.421 & 0.131 & 0.039 & 265 & 1 & 0.040 & 2.00 & 0.076 & 0.53 & 0.03 \\
\hline NIMT & 3.368 & 0.016 & 0.041 & 37224 & 1 & -0.013 & 2.00 & 0.081 & 0.16 & 0.03 \\
\hline NMC/A*STAR & 3.356 & 0.046 & 0.040 & 10000 & 1 & -0.025 & 2.00 & 0.079 & 0.31 & 0.03 \\
\hline CMS/ITRI & 3.381 & 0.040 & 0.051 & 17 & 1 & 0.000 & 2.00 & 0.101 & 0.00 & 0.02 \\
\hline NMISA & 3.385 & 0.036 & 0.080 & 10000 & 1 & 0.004 & 2.00 & 0.160 & 0.03 & 0.01 \\
\hline \multirow[t]{2}{*}{ INMETRO } & 3.364 & 0.009 & 0.039 & 10000 & 1 & -0.017 & 2.00 & 0.076 & 0.23 & 0.03 \\
\hline & $x_{\mathrm{w}}$ & & $u\left(x_{\mathrm{w}}\right)$ & $v_{\text {eff }}$ & $N-1$ & & $\boldsymbol{k}_{\text {ref }}$ & & & \\
\hline Reference value & 3.381 & & 0.007 & 808 & 15 & & 2.00 & & & \\
\hline \multirow[t]{5}{*}{ 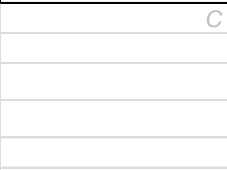 } & $4.53 E-05$ & & & & & & & & & \\
\hline & & & & & & \multicolumn{2}{|c|}{ Consistency: } & & & \\
\hline & & & & & & $u_{\text {ext }}$ & 0.008 & & & \\
\hline & & & & & & $R_{\mathrm{B}}$ & 1.246 & Birge ok & & \\
\hline & & & & & & Limit & 1.315 & & & \\
\hline
\end{tabular}

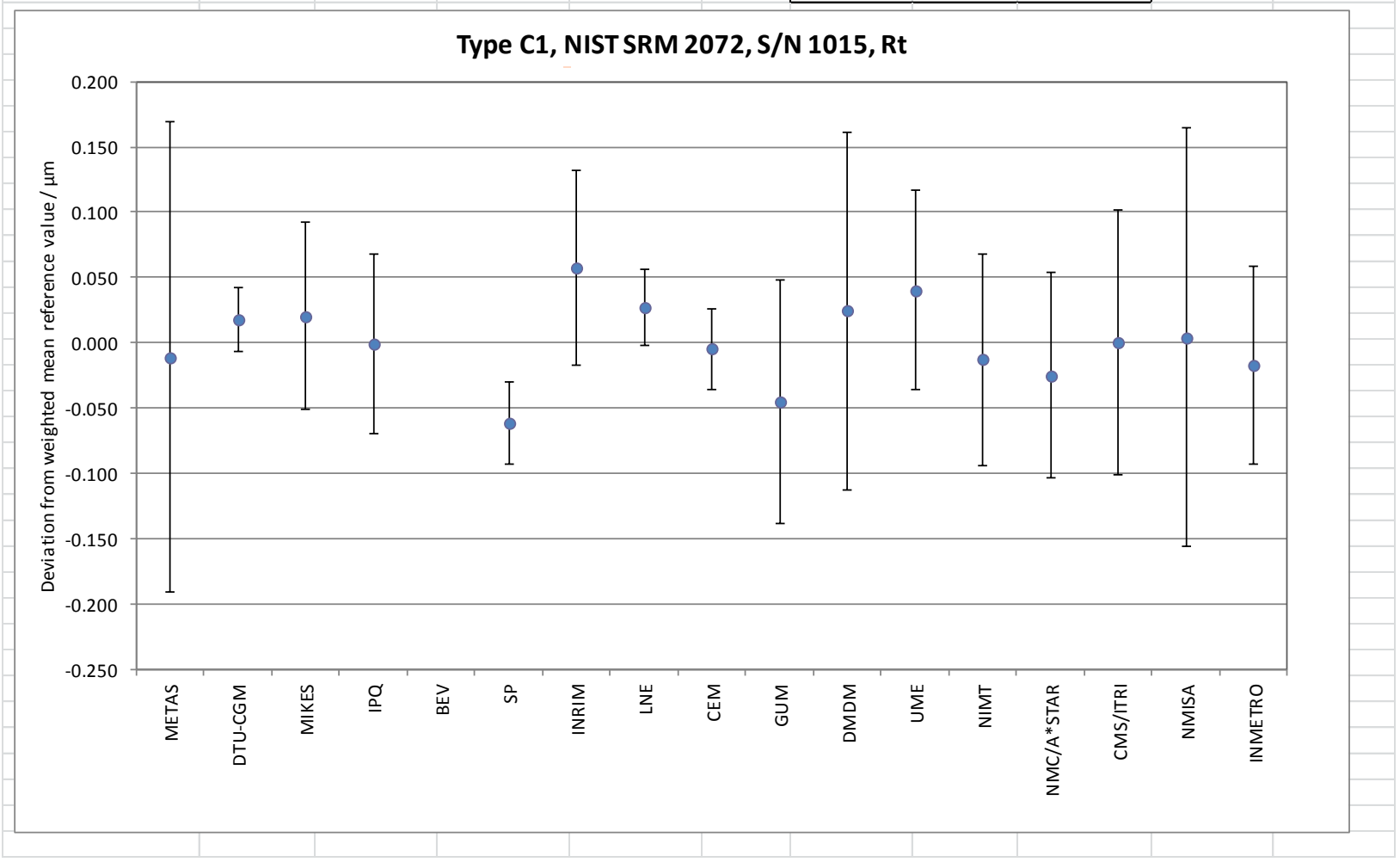




\begin{tabular}{|c|c|c|c|c|c|c|c|c|c|c|}
\hline \multirow[b]{2}{*}{ select gauge } & \multirow[b]{2}{*}{24} & \multirow{2}{*}{\multicolumn{3}{|c|}{ Type C1, NIST SRM 2072, S/N 1015, RSm }} & \multirow{2}{*}{\multicolumn{2}{|c|}{\begin{tabular}{|l|} 
use 1 or 0 to \\
in- or exclude
\end{tabular}}} & \multirow{2}{*}{$\begin{array}{c}\text { choose: } \\
k=2\end{array}$} & \multirow[b]{3}{*}{$U\left(x_{i}-x_{\text {ref }}\right) / \mu \mathrm{m}$} & \multirow[b]{3}{*}{$E \mathrm{n}$} & \multirow[b]{3}{*}{$w_{i}$} \\
\hline & & & & & & & & & & \\
\hline Institute & $x_{\mathrm{i}} / \mu \mathrm{m}$ & $\sigma_{i} / \mu \mathrm{m}$ & $u_{\mathrm{i}} / \mu \mathrm{m}$ & $v_{\text {eff }}$ & on/off & $\left(x_{i}-x_{\mathrm{w}}\right) / \mu \mathrm{m}$ & $k$ & & & \\
\hline METAS & 101.658 & 0.068 & 0.063 & 26 & 1 & 0.024 & 2.00 & 0.108 & 0.22 & 0.26 \\
\hline DTU-CGM & 101.600 & 0.000 & 0.390 & 10000 & 1 & -0.034 & 2.00 & 0.777 & 0.04 & 0.01 \\
\hline MIKES & 100.772 & 0.814 & 0.350 & 11 & 1 & -0.862 & 2.00 & 0.697 & 1.24 & 0.01 \\
\hline $\mathrm{IPQ}$ & 101.320 & 0.047 & 0.059 & 90 & 0 & -0.314 & 2.00 & 0.134 & 2.34 & 0.00 \\
\hline BEV & 0.000 & 0.000 & 0.000 & \#NV & 0 & \#NV & \#NV & \#NV & \#NV & 0.00 \\
\hline $\mathrm{SP}$ & 101.300 & 0.200 & 0.185 & 11 & 1 & -0.334 & 2.00 & 0.364 & 0.92 & 0.03 \\
\hline INRIM & 101.700 & 0.110 & 0.153 & 50 & 1 & 0.066 & 2.00 & 0.299 & 0.22 & 0.04 \\
\hline LNE & 101.662 & 0.053 & 0.044 & 32 & 1 & 0.028 & 2.00 & 0.060 & 0.47 & 0.53 \\
\hline CEM & 101.700 & 0.057 & 0.400 & 10000 & 1 & 0.066 & 2.00 & 0.797 & 0.08 & 0.01 \\
\hline GUM & 101.600 & 0.005 & 0.150 & 100 & 1 & -0.034 & 2.00 & 0.293 & 0.12 & 0.05 \\
\hline DMDM & 101.664 & 0.045 & 0.250 & 10000 & 1 & 0.030 & 2.00 & 0.496 & 0.06 & 0.02 \\
\hline UME & 102.007 & 0.100 & 0.883 & 215 & 1 & 0.373 & 2.00 & 1.765 & 0.21 & 0.00 \\
\hline NIMT & 101.680 & 0.434 & 0.376 & 506 & 1 & 0.046 & 2.00 & 0.749 & 0.06 & 0.01 \\
\hline NMC/A*STAR & 101.100 & 0.683 & 0.300 & 10000 & 1 & -0.534 & 2.00 & 0.597 & 0.89 & 0.01 \\
\hline $\mathrm{CMS} / \mathrm{ITRI}$ & 101.553 & 0.727 & 0.188 & 14 & 1 & -0.081 & 2.00 & 0.370 & 0.22 & 0.03 \\
\hline NMISA & 101.688 & 0.102 & 2.040 & 10000 & 1 & 0.054 & 2.00 & 4.080 & 0.01 & 0.00 \\
\hline \multirow[t]{2}{*}{ INMETRO } & 101.995 & 0.066 & 0.500 & 10000 & 1 & 0.361 & 2.00 & 0.998 & 0.36 & 0.00 \\
\hline & $x_{\mathrm{w}}$ & & $u\left(x_{w}\right)$ & $v_{\text {eff }}$ & $N-1$ & & $\boldsymbol{k}_{\text {ref }}$ & & & \\
\hline Reference value & 101.634 & & 0.032 & 86 & 14 & & 2.00 & & & \\
\hline \multirow[t]{5}{*}{ 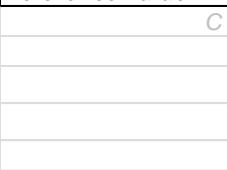 } & 1.03E-03 & & & & & & & & & \\
\hline & & & & & & \multicolumn{2}{|c|}{ Consistency: } & & & \\
\hline & & & & & & $u_{\text {ext }}$ & 0.032 & & & \\
\hline & & & & & & $R_{\mathrm{B}}$ & 1.008 & Birge ok & & \\
\hline & & & & & & Limit & 1.325 & & & \\
\hline
\end{tabular}

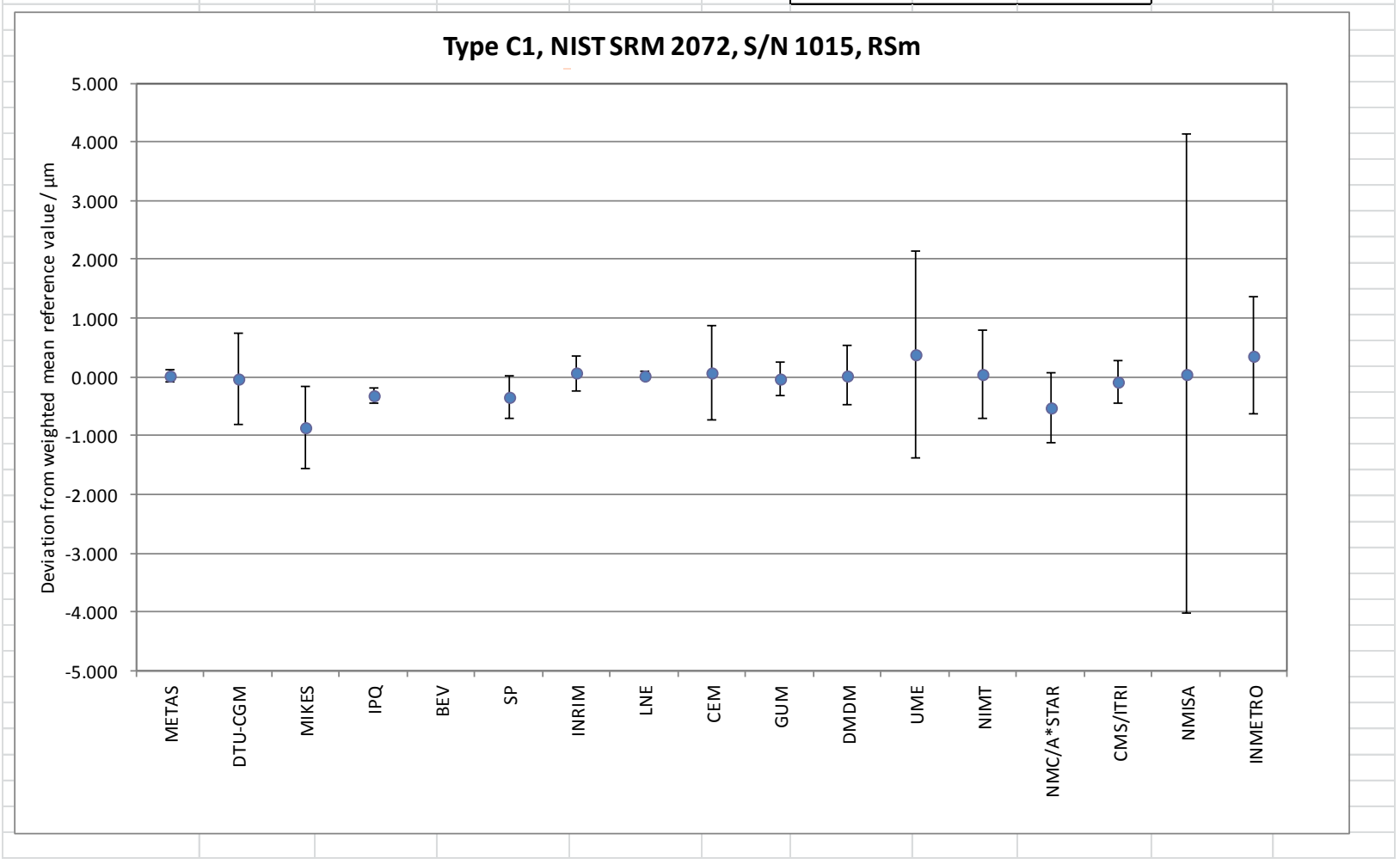




\subsection{Summary of the $E_{n}$ values}

In Table 5 the $E_{n}$ values as shown in the tables of section 8.2 (i.e. after exclusion of inconsistent results) are summarized, with $E_{n}>1$ highlighted.

Table 5. $E_{n}$ values of the originally reported results.

\begin{tabular}{|c|c|c|c|c|c|c|c|c|c|c|c|}
\hline \multirow[b]{2}{*}{ Institute } & \multicolumn{6}{|c|}{ Type A2, KNT 2060/01, S/N 0589606} & \multicolumn{5}{|c|}{ Type C1, PGN 10, no 6820605} \\
\hline & $\mathrm{R} 1, \mathrm{~d}$ & $\mathrm{R} 2, \mathrm{~d}$ & $\mathrm{R} 3, \mathrm{~d}$ & $\mathrm{R} 4, \mathrm{~d}$ & $\mathrm{R} 5, \mathrm{~d}$ & $\mathrm{R} 6, \mathrm{~d}$ & $\mathrm{Ra}$ & $\mathrm{Rq}$ & $\mathrm{Rz}$ & Rt & $\mathrm{RSm}$ \\
\hline METAS & 0.01 & 0.26 & 0.06 & 0.09 & 0.00 & 0.35 & 0.18 & 0.18 & 0.28 & 0.18 & 0.29 \\
\hline DTU-CGM & 0.11 & 0.20 & 0.14 & 0.47 & 0.21 & 0.45 & 0.50 & 0.38 & 0.49 & 0.55 & 0.08 \\
\hline MIKES & 0.22 & 0.16 & 0.29 & 0.00 & 0.02 & 0.05 & 0.07 & 0.13 & 0.19 & 0.29 & 1.11 \\
\hline IPQ & 0.11 & 0.15 & 0.67 & 1.15 & 0.37 & 0.85 & 0.07 & 0.05 & 0.63 & 0.49 & 3.56 \\
\hline BEV & 1.84 & 1.04 & 1.68 & 0.92 & 0.01 & 0.77 & 0.50 & 0.54 & 1.04 & 1.23 & 0.06 \\
\hline SP & 0.41 & 0.12 & 0.16 & 0.03 & 0.05 & 0.10 & 0.27 & 0.29 & 0.52 & 0.42 & 0.18 \\
\hline INRIM & 0.55 & 0.04 & 0.33 & 0.06 & 0.27 & 0.01 & 0.07 & 0.07 & 0.13 & 0.11 & 0.01 \\
\hline LNE & 0.14 & 0.15 & 0.26 & 0.21 & 0.01 & 0.05 & 0.31 & 0.29 & 0.56 & 0.48 & 0.83 \\
\hline CEM & 0.41 & 0.42 & 0.52 & 0.32 & 0.43 & 0.51 & 0.02 & 0.08 & 0.05 & 0.06 & 0.11 \\
\hline GUM & 0.24 & 0.19 & 0.44 & 0.07 & 0.44 & 0.03 & 0.75 & 0.81 & 0.48 & 0.22 & 0.12 \\
\hline DMDM & 0.50 & 0.39 & 0.17 & 0.05 & 0.12 & 0.01 & 0.19 & 0.15 & 0.12 & 0.13 & 0.01 \\
\hline UME & 0.10 & 0.21 & 0.05 & 0.20 & 0.07 & 0.06 & 0.12 & 0.17 & 0.14 & 0.12 & 0.18 \\
\hline NIMT & 0.30 & 0.20 & 0.69 & 0.69 & 0.68 & 0.65 & 0.26 & 0.23 & 0.01 & 0.00 & 0.04 \\
\hline NMC/A*STAR & 0.05 & 0.11 & 0.07 & 0.06 & 0.27 & 0.09 & 0.22 & 0.23 & 0.43 & 0.39 & 2.67 \\
\hline CMS/ITRI & 0.61 & 0.55 & 0.71 & 0.53 & 0.23 & 0.22 & 0.02 & 0.04 & 0.06 & 0.05 & 1.90 \\
\hline NMISA & 2.19 & 1.13 & 1.07 & 0.55 & 0.20 & 0.20 & 0.20 & 0.19 & 0.25 & 0.23 & 0.00 \\
\hline INMETRO & 0.18 & 0.02 & 0.10 & 0.24 & 0.37 & 0.08 & 0.07 & 0.02 & 0.03 & 0.05 & 0.31 \\
\hline
\end{tabular}

\begin{tabular}{|c|c|c|c|c|c|c|c|c|c|c|c|c|c|}
\hline \multirow[b]{2}{*}{ Institute } & \multicolumn{4}{|c|}{ Type D1, S/N 021} & \multicolumn{4}{|c|}{ Type D1, KNT 2070/03, S/N 0986} & \multicolumn{5}{|c|}{ Type C1, NIST SRM 2072, S/N 1015} \\
\hline & $\mathrm{Ra}$ & $\mathrm{Rq}$ & $\mathrm{Rz}$ & $\mathrm{Rt}$ & $\mathrm{Ra}$ & $\mathrm{Rq}$ & $\mathrm{Rz}$ & Rt & $\mathrm{Ra}$ & $\mathrm{Rq}$ & $\mathrm{Rz}$ & Rt & $\mathrm{RSm}$ \\
\hline METAS & 0.72 & 0.70 & 0.59 & 0.66 & 0.01 & 0.09 & 0.03 & 0.04 & 0.04 & 0.07 & 0.02 & 0.06 & 0.22 \\
\hline DTU-CGM & 1.95 & 2.05 & 1.62 & 0.23 & 0.12 & 0.16 & 0.19 & 0.12 & 0.13 & 0.06 & 0.74 & 0.74 & 0.04 \\
\hline MIKES & 0.41 & 0.34 & 0.27 & 0.57 & 0.13 & 0.16 & 0.76 & 0.54 & 0.24 & 0.24 & 0.20 & 0.29 & 1.24 \\
\hline IPQ & 0.19 & 0.23 & 0.19 & 0.07 & 0.00 & 0.07 & 0.05 & 0.06 & 0.13 & 0.12 & 0.06 & 0.01 & 2.34 \\
\hline \multicolumn{14}{|l|}{ BEV } \\
\hline SP & 0.05 & 0.19 & 0.21 & 0.14 & 0.01 & 0.01 & 0.31 & 0.61 & 0.16 & 0.11 & 1.71 & 1.98 & 0.92 \\
\hline INRIM & 0.22 & 0.16 & 0.40 & 0.21 & 0.00 & 0.03 & 0.05 & 0.28 & 0.13 & 0.19 & 0.53 & 0.76 & 0.22 \\
\hline LNE & 1.13 & 1.27 & 0.90 & 0.95 & 0.01 & 0.04 & 0.21 & 0.26 & 0.01 & 0.03 & 0.83 & 0.94 & 0.47 \\
\hline CEM & 0.75 & 0.76 & 0.22 & 0.33 & 0.17 & 0.23 & 0.26 & 0.27 & 0.11 & 0.17 & 0.18 & 0.15 & 0.08 \\
\hline GUM & 1.04 & 1.17 & 1.63 & 2.03 & 0.06 & 0.08 & 0.32 & 0.77 & 0.17 & 0.18 & 0.44 & 0.48 & 0.12 \\
\hline DMDM & 0.43 & 0.31 & 0.01 & 0.32 & 0.10 & 0.17 & 0.31 & 0.21 & 0.22 & 0.21 & 0.18 & 0.18 & 0.06 \\
\hline UME & 1.13 & 0.87 & 0.26 & 0.11 & 0.11 & 0.16 & 0.04 & 0.04 & 0.01 & 0.02 & 0.34 & 0.53 & 0.21 \\
\hline NIMT & 0.53 & 0.66 & 0.83 & 0.55 & 0.00 & 0.08 & 0.05 & 0.01 & 0.38 & 0.79 & 0.46 & 0.16 & 0.06 \\
\hline NMC/A*STAR & 0.69 & 0.79 & 1.40 & 1.62 & 0.00 & 0.08 & 0.07 & 0.21 & 0.04 & 0.07 & 0.35 & 0.31 & 0.89 \\
\hline CMS/ITRI & 1.97 & 1.87 & 0.96 & 0.75 & 0.01 & 0.10 & 0.15 & 0.01 & 0.20 & 0.16 & 0.54 & 0.00 & 0.22 \\
\hline NMISA & 0.82 & 0.93 & 1.00 & 0.94 & 0.18 & 0.21 & 0.32 & 0.13 & 0.00 & 0.01 & 0.01 & 0.03 & 0.01 \\
\hline INMETRO & 0.24 & 0.18 & 0.56 & 0.38 & 0.08 & 0.11 & 0.43 & 0.16 & 0.00 & 0.02 & 0.12 & 0.23 & 0.36 \\
\hline
\end{tabular}

\subsection{Discussion of results}

In spite of a relatively large number of inconsistent results, the overall agreement is considered to be satisfactory. A number of inconsistent results can be explained (see section 8.5).

- 32 out of 395 results are not consistent with the reference value, i.e. $E_{n}>1$.

- 11 out of 17 laboratories had at least one inconsistent result.

- The largest number (15) of inconsistent results was found on the standard with the least quality, i.e. Rubert D1. 
- The degradation of the quality of the standards in the course of the comparison due to surface damages did hardly affect the measurement results. There is no clear trend visible from the first to the last participant, even the last participant achieved excellent results, and the stability measurements made by the pilot were all consistent (see section 6.1).

- Pt values for the type A2 standard were part of the protocol in order to be compatible to the protocol of the preceding comparison EURAMET.L-K8, but do not correspond to the standardized profile depth. They were included in the evaluation spreadsheet of this comparison, but are not part of the draft B report. Therefore no further analysis is carried out on this parameter.

\subsection{Changes to results after Draft A report}

After sending draft A report, the pilot received three requests to change values or uncertainties:

\subsubsection{BEV request from 13.02.2015}

I noticed to actually have sent values for the wrong measurand for the type A2 standard. Originally our values are for the central trace (as written on our report) where "the average result together with the standard deviation" was requested. This makes only minor changes to the actual values but the standard deviation is of course much higher (and also the uncertainty).

I have re-evaluated the $d$ parameter according to this.

Attached was a report file with slightly different values and increased uncertainties.

\subsubsection{NMISA comment from 06.03.2015 and report from 22.04.2015}

I checked the data as the groove stds was far out and did not expect it. The laboratory had a Taylor Hobson Form Talysurf series which was upgraded to a PGI system with a newer version of the same software only months before the inter-comparison. While performing the measurements for the groove standard, Type A2, KNT 2060/01, S/N 0589606, a mistake was made in the analysis of the results. The filter is selected in two places, firstly, the primary filter and in the next instance, instead of no filter in place, we selected the primary filter again.

Our results were thus systematically lower than should be. This came to light when Draft $A$ of the intercomparison report was published. A re-analysis of all the measurements for the groove depth standard was done and the results are attached.

Attached was a report file with values changed accordingly.

\subsubsection{IPQ request from 12.03.2015}

I ask if it is possible to consider the following updates: I detect a mistake in the IPQ reported values for the surface roughness standard Type A2, KNT 2060/01, S/N 0589606, R4, d (instead of $2.64 \mu \mathrm{m}$ it is $2.68 \mu \mathrm{m})$. I also made an update of the measurement uncertainty for the parameter RSm of the two standards (Type C1, PGN 10, no 682060 5, RSm and Type C1, NIST SRM 2072, S/N 1015, RSm) adding a new uncertainty component.

Additional information was received from IPQ to justify and support the above mentioned changes. The uncertainties of IPQ for RSm were changed from $77 \mathrm{~nm}$ to $321 \mathrm{~nm}$ and from $59 \mathrm{~nm}$ to $214 \mathrm{~nm}$, respectively, introduced in the spreadsheet EURAMET.L-K8.2013-revised values.XIsx and for the analysis in section 8.6.3. 


\subsection{Comments received after Draft B.1 report}

After sending draft B.1 report, the pilot received the following comments:

\subsubsection{INMETRO comment from 29.04.2015}

I am really sorry, but I made a rough mistake when declaring our measurement uncertainties. Instead of sending you the "uc" uncertainties, I declared the expanded ones (U). All our expanded uncertainties are based in the ones that we have in the KCDB App. C.

For the calibration of depth setting standards they are:

$(20+2 H) n m ; H=d$ or Pt (in $\mu m$ )

For the calibration of roughness standards they are:

$(10+20 P) \mathrm{nm} ; \mathrm{P}=$ vertical parameters (in $\mu \mathrm{m}$ )

If it would be possible, I ask you, please, to correct our "ui " values in the tables, dividing them by 2, as well plotting the graphs considering it.

This is an obvious mistake. In order to get a more reliable evaluation of the reference values and the degrees of equivalence, the uncertainties of INMETRO were divided by 2 , and all data presented in section 8.2 were updated.

\subsubsection{NMC/A*STAR comment from 18.05.2015}

1) The supplier in Singapore upgraded the software and we at NMC completed the re-analysis of those raw data captured during the comparison measurement at NMC. It was confirmed that only RSm values were wrongly calculated....

2) The RSm values of two comparison samples (PNG 10 and NIST SRM2072) were re-calculated and corresponding uncertainties were also slightly changed due to the change of the standard deviation. The results in detail are summarized in attachment, in which new RSm values of two samples are listed....

3) Since our results ( $R z \& R t$ ) for the sample (Type $D 1, S / N$ 021) have the En value larger than 1, we need to study the root cause. As requested before, could you please kindly arrange to send the sample for us to do re-measurement at NMC?

Attached were detailed reports on re-analysis of RSm-values. The following revised values were introduced in the spreadsheet EURAMET.L-K8.2013-revised values.xIsx and for the analysis in section 8.7:

\begin{tabular}{|l|l|l|l|l|c|}
\hline Standard & Parameter & Value $(\boldsymbol{\mu m})$ & $\boldsymbol{\sigma}(\boldsymbol{\mu m})$ & uc $(\mathbf{n m})$ & veff \\
\hline PGN 10, no 682060 5, & RSm & 199.978 & 0.058 & 442 & $\infty$ \\
\hline NIST SRM 2072, S/N 1015 & RSm & 101.663 & 0.077 & 228 & $\infty$ \\
\hline
\end{tabular}

\subsubsection{GUM comment from 19.05.2015}

We have once more checked very carefully our results, especially those concerning roughness standard type D1, SN 021. As you know this standard is of the worst quality with scratches and other damages. We have already noted the state of this standard in our first report.

While checking our printed measurements protocol we have noticed a mistake. Instead of giving you the real values of measurement uncertainties we claimed values given in our CMCs. Our measurements protocol prints both values for each roughness parameter. Usually these values are almost the same but at this case they have differed significantly. So if it is possible we would like to ask you to change our uncertainties values concerning $R z$ and $R t$ parameters of roughness standard type $D 1, S N 021$. For $R z$ 
parameter we would like to change uncertainty value from $34 \mathrm{~nm}$ on $79 \mathrm{~nm}$ and for Rt parameter from $36 \mathrm{~nm}$ on $114 \mathrm{~nm}$.

We want also to add that the standard deviation values for $R t$ and $R z$ parameters we have measured for this standard exceed the tolerance $3 \%$ value given in the ISO 5436, 5,4\% (0,054 $\mu \mathrm{m})$ for Rt parameter and 3,5\% $(0,035 \mu \mathrm{m})$ for Rz parameter.

The above revised uncertainties were introduced in the spreadsheet EURAMET.L-K8.2013-revised values.xIsx and for the analysis in section 8.6.3.

\subsection{En-values with results revised after draft A and draft B.1 report}

The Excel spreadsheet EURAMET.L-K8.2013-revised values.xIsx contains values revised for BEV, NMISA and IPQ, according to section 8.5.1, 8.5.2, 8.5.3, 8.6.2 and 8.6.3. The En-values for the parameters subject to changes were calculated again and are summarized in Table 6 . Values in red or their uncertainties were changed.

It has to be noted, that this analysis is in fact outside the scope of the key comparison, since the rules for CIPM MRA comparisons do not allow to change any results after draft A report. Therefore the key comparison reference values and the degrees of equivalence resulting from this comparison are those reported in the tables of section 8.2, the $E_{n}$ values those of Table 5 in section 8.3. The partly substantial changes of the values from BEV and NMISA for the type A2 standard have an influence on the reference values and thus also to the $E_{n}$ values of the other laboratories. These changes are certainly justified, since the original values refer to the wrong measurand, and one might argue, that the reference values after these changes are more reliable. For this reason, it is worthwhile to show the impact of the revised results on the $E_{n}$ values, although, as stated above, outside the scope of the key comparison.

Table 6. $E_{n}$ values of the revised results.

\begin{tabular}{|c|c|c|c|c|c|c|c|c|c|c|c|}
\hline \multirow[b]{2}{*}{ Institute } & \multicolumn{6}{|c|}{ Type A2, KNT 2060/01, S/N 0589606} & \multicolumn{5}{|c|}{ Type C1, PGN 10, no 6820605} \\
\hline & $\mathrm{R} 1, \mathrm{~d}$ & $R 2, d$ & $R 3, d$ & $\mathrm{R} 4, \mathrm{~d}$ & R5, d & $R 6, d$ & $\mathrm{Ra}$ & $\mathrm{Rq}$ & $\mathrm{Rz}$ & $\mathrm{Rt}$ & $\mathrm{RSm}$ \\
\hline METAS & 0.07 & 0.28 & 0.16 & 0.23 & 0.05 & 0.16 & 0.18 & 0.18 & 0.28 & 0.18 & 0.19 \\
\hline DTU-CGM & 0.16 & 0.22 & 0.22 & 0.39 & 0.23 & 0.40 & 0.50 & 0.38 & 0.49 & 0.55 & 0.07 \\
\hline MIKES & 0.15 & 0.20 & 0.18 & 0.09 & 0.04 & 0.01 & 0.07 & 0.13 & 0.19 & 0.29 & 1.10 \\
\hline IPQ & 0.09 & 0.14 & 0.64 & 0.45 & 0.38 & 0.79 & 0.07 & 0.05 & 0.63 & 0.49 & 0.98 \\
\hline BEV & 0.86 & 0.43 & 0.92 & 0.35 & 0.24 & 0.53 & 0.50 & 0.54 & 1.04 & 1.23 & 0.03 \\
\hline SP & 0.31 & 0.07 & 0.03 & 0.10 & 0.03 & 0.16 & 0.27 & 0.29 & 0.52 & 0.42 & 0.17 \\
\hline INRIM & 0.21 & 0.01 & 0.14 & 0.13 & 0.24 & 0.10 & 0.07 & 0.07 & 0.13 & 0.11 & 0.02 \\
\hline LNE & 0.21 & 0.12 & 0.18 & 0.13 & 0.00 & 0.00 & 0.31 & 0.29 & 0.56 & 0.48 & 0.75 \\
\hline CEM & 0.18 & 0.31 & 0.22 & 0.01 & 0.54 & 0.34 & 0.02 & 0.08 & 0.05 & 0.06 & 0.09 \\
\hline GUM & 0.28 & 0.21 & 0.52 & 0.03 & 0.41 & 0.18 & 0.75 & 0.81 & 0.48 & 0.22 & 0.16 \\
\hline DMDM & 0.57 & 0.43 & 0.24 & 0.02 & 0.10 & 0.05 & 0.19 & 0.15 & 0.12 & 0.13 & 0.00 \\
\hline UME & 0.19 & 0.25 & 0.09 & 0.08 & 0.04 & 0.01 & 0.12 & 0.17 & 0.14 & 0.12 & 0.18 \\
\hline NIMT & 0.23 & 0.17 & 0.59 & 0.63 & 0.70 & 0.61 & 0.26 & 0.23 & 0.01 & 0.00 & 0.05 \\
\hline NMC/A*STAR & 0.01 & 0.14 & 0.04 & 0.07 & 0.24 & 0.22 & 0.22 & 0.23 & 0.43 & 0.39 & 0.03 \\
\hline CMS/ITRI & 0.39 & 0.45 & 0.47 & 0.38 & 0.26 & 0.13 & 0.02 & 0.04 & 0.06 & 0.05 & 1.94 \\
\hline NMISA & 0.34 & 0.24 & 0.14 & 0.04 & 0.09 & 0.00 & 0.20 & 0.19 & 0.25 & 0.23 & 0.00 \\
\hline INMETRO & 0.23 & 0.05 & 0.00 & 0.36 & 0.34 & 0.07 & 0.07 & 0.02 & 0.03 & 0.05 & 0.32 \\
\hline
\end{tabular}




\begin{tabular}{|c|c|c|c|c|c|c|c|c|c|c|c|c|c|}
\hline \multirow[b]{2}{*}{ Institute } & \multicolumn{4}{|c|}{ Type D1, S/N 021} & \multicolumn{4}{|c|}{ Type D1, KNT 2070/03, S/N 0986} & \multicolumn{5}{|c|}{ Type C1, NIST SRM 2072, S/N 1015} \\
\hline & $\mathrm{Ra}$ & $\mathrm{Rq}$ & $\mathrm{Rz}$ & Rt & $\mathrm{Ra}$ & $\mathrm{Rq}$ & $\mathrm{Rz}$ & Rt & $\mathrm{Ra}$ & $\mathrm{Rq}$ & $\mathrm{Rz}$ & Rt & $\mathrm{RSm}$ \\
\hline METAS & 0.72 & 0.70 & 0.60 & 0.67 & 0.01 & 0.09 & 0.03 & 0.04 & 0.04 & 0.07 & 0.02 & 0.06 & 0.23 \\
\hline DTU-CGM & 1.95 & 2.05 & 1.61 & 0.24 & 0.12 & 0.16 & 0.19 & 0.12 & 0.13 & 0.06 & 0.74 & 0.74 & 0.04 \\
\hline MIKES & 0.41 & 0.34 & 0.29 & 0.60 & 0.13 & 0.16 & 0.76 & 0.54 & 0.24 & 0.24 & 0.20 & 0.29 & 1.24 \\
\hline IPQ & 0.19 & 0.23 & 0.18 & 0.07 & 0.00 & 0.07 & 0.05 & 0.06 & 0.13 & 0.12 & 0.06 & 0.01 & 0.74 \\
\hline \multicolumn{14}{|l|}{ BEV } \\
\hline SP & 0.05 & 0.19 & 0.24 & 0.11 & 0.01 & 0.01 & 0.31 & 0.61 & 0.16 & 0.11 & 1.71 & 1.98 & 0.91 \\
\hline INRIM & 0.22 & 0.16 & 0.41 & 0.21 & 0.00 & 0.03 & 0.05 & 0.28 & 0.13 & 0.19 & 0.53 & 0.76 & 0.22 \\
\hline LNE & 1.13 & 1.27 & 0.87 & 0.93 & 0.01 & 0.04 & 0.21 & 0.26 & 0.01 & 0.03 & 0.83 & 0.94 & 0.47 \\
\hline CEM & 0.75 & 0.76 & 0.23 & 0.34 & 0.17 & 0.23 & 0.26 & 0.27 & 0.11 & 0.17 & 0.18 & 0.15 & 0.08 \\
\hline GUM & 1.04 & 1.17 & 0.71 & 0.66 & 0.06 & 0.08 & 0.32 & 0.77 & 0.17 & 0.18 & 0.44 & 0.48 & 0.11 \\
\hline DMDM & 0.43 & 0.31 & 0.02 & 0.30 & 0.10 & 0.17 & 0.31 & 0.21 & 0.22 & 0.21 & 0.18 & 0.18 & 0.06 \\
\hline UME & 1.13 & 0.87 & 0.25 & 0.12 & 0.11 & 0.16 & 0.04 & 0.04 & 0.01 & 0.02 & 0.34 & 0.53 & 0.21 \\
\hline NIMT & 0.53 & 0.66 & 0.82 & 0.55 & 0.00 & 0.08 & 0.05 & 0.01 & 0.38 & 0.79 & 0.46 & 0.16 & 0.06 \\
\hline NMC/A*STAR & 0.69 & 0.79 & 1.42 & 1.63 & 0.00 & 0.08 & 0.07 & 0.21 & 0.04 & 0.07 & 0.35 & 0.31 & 0.07 \\
\hline CMS/ITRI & 1.97 & 1.87 & 0.96 & 0.74 & 0.01 & 0.10 & 0.15 & 0.01 & 0.20 & 0.16 & 0.54 & 0.00 & 0.22 \\
\hline NMISA & 0.82 & 0.93 & 1.01 & 0.95 & 0.18 & 0.21 & 0.32 & 0.13 & 0.00 & 0.01 & 0.01 & 0.03 & 0.01 \\
\hline INMETRO & 0.24 & 0.18 & 0.58 & 0.38 & 0.08 & 0.11 & 0.43 & 0.16 & 0.00 & 0.02 & 0.12 & 0.23 & 0.36 \\
\hline
\end{tabular}

\subsection{Linking of result to other comparisons}

The comparison followed the protocol of the former comparison EURAMET.L-K8.2009 as closely as possible. Also in the comparison APMP.L-K8.2008 similar artefacts were used. To what extent the three comparisons can be linked to each other, and whether this brings any added value, needs to be investigated by the CCL Task Group on comparison linking (TG-L) once the final reports of all three comparisons are available. 


\section{Softgauges}

\subsection{Description of the files}

Two softgauges with type F1 reference data were sent to the participants. The files METAS_Aperiodic and METAS_Periodic were available in *.smd and *.prf format, the former according to ISO 5436-2, the latter to be compatible with Taylor Hobson Ultra software. The conditions for evaluation and the parameters to be determined are described in sections 4.6 and 5.4 .

The aperiodic softgauge was produced from a measurement on a fine aperiodic roughness standard. The periodic softgauge was numerically generated from the superposition of two periodic waves with $100 \mu \mathrm{m}$ and $800 \mu \mathrm{m}$ wavelength and $100 \mathrm{~nm}$ and $20 \mathrm{~nm}$ amplitude, respectively, and adding some random noise with $5 \mathrm{~nm}$ amplitude.

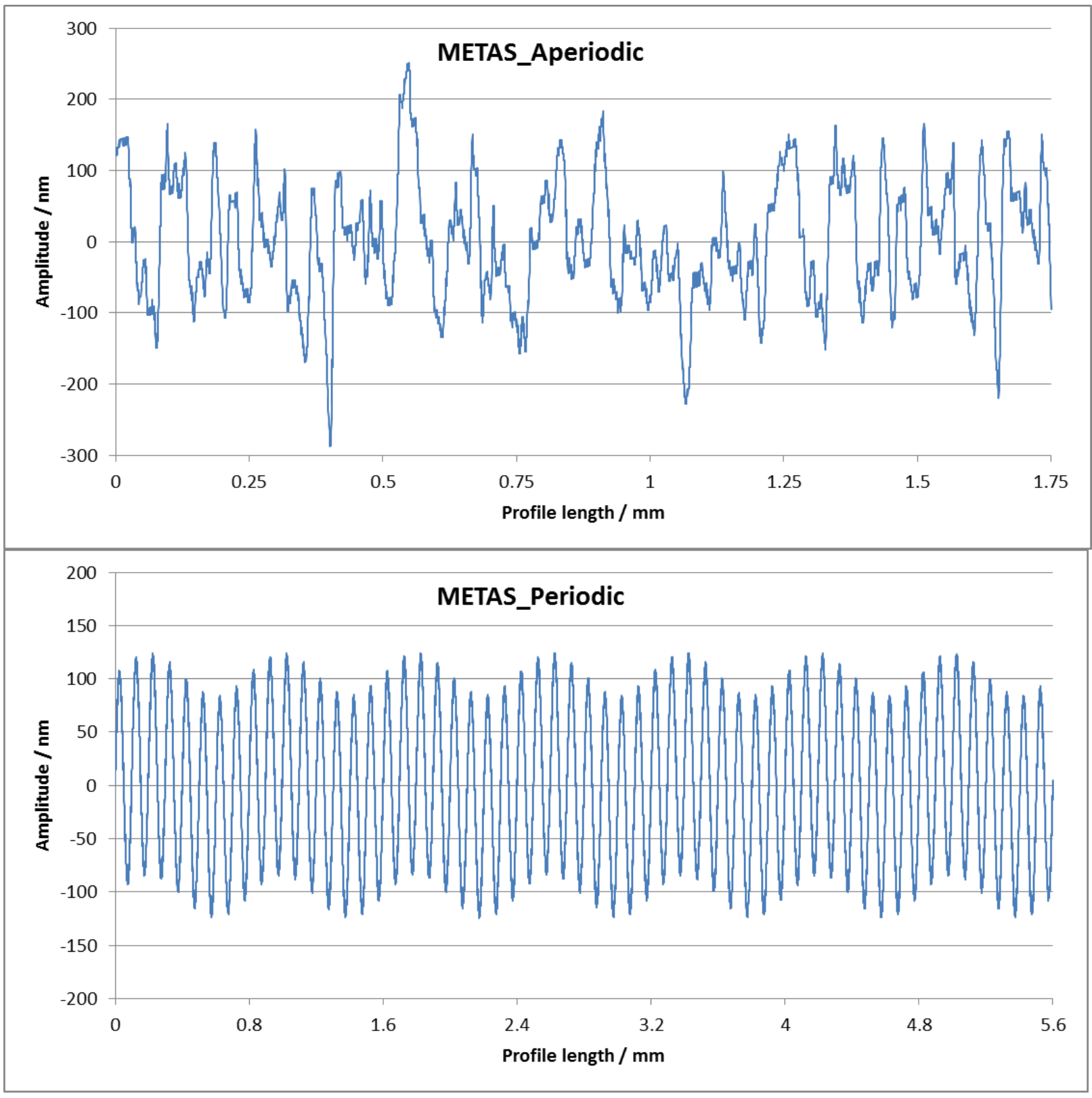

Figure 9. Profiles of the two softgauges. 


\subsection{Results of participants}

Table 7. Results reported for METAS_Periodic.smd with mean and standard deviation (UME excluded from mean and standard deviation).

\begin{tabular}{|l|l|l|l|l|l|}
\hline & $\mathrm{Ra}(\mu \mathrm{m})$ & $\mathrm{Rq}(\mu \mathrm{m})$ & $\mathrm{Rz}(\mu \mathrm{m})$ & $\mathrm{Rt}(\mu \mathrm{m})$ & $\mathrm{RSm}(\mu \mathrm{m})$ \\
\hline METAS & 0.06376 & 0.071 & 0.2217 & 0.2234 & 99.815 \\
DTU_1 & 0.064 & 0.071 & 0.221 & 0.226 & 100.0 \\
DTU_2 & 0.064 & 0.071 & 0.222 & 0.223 & 100.0 \\
MIKES & 0.0637 & 0.071 & 0.2218 & 0.2235 & 100 \\
SP & 0.0638 & 0.071 & 0.2216 & 0.2234 & 100 \\
LNE & 0.06376512 & 0.07100243 & 0.22161773 & 0.2232598 & 100.092183 \\
INRIM_1 & 0.0638 & 0.071 & 0.2217 & 0.2234 & 99.91 \\
INRIM_2 & 0.0638 & 0.071 & 0.2217 & 0.2234 & 99.96 \\
UME & 0.064 & 0.071 & 0.229 & 0.229 & 100.061 \\
NIMT & 0.0638 & 0.071 & 0.2217 & 0.2234 & - \\
CEM & 0.063765 & 0.071002 & 0.221618 & 0.22326 & 100.092 \\
NMC/A*STAR & 0.0637 & 0.071 & 0.2218 & 0.2235 & 100 \\
CMS & 0.063767 & 0.071004 & 0.221688 & 0.223412 & 99.871429 \\
INMETRO & 0.0638 & 0.071 & 0.2216 & 0.2234 & 100.2837 \\
\hline Mean & 0.063804 & 0.071001 & 0.22166 & 0.22356 & 100.002 \\
StdDev & 0.000093 & 0.000001 & 0.00023 & 0.00074 & 0.120 \\
\hline
\end{tabular}

Table 8. Results reported for METAS_Aperiodic.smd with mean and standard deviation (UME excluded from mean and standard deviation).

\begin{tabular}{|l|l|l|l|l|l|}
\hline & Ra $(\mu \mathrm{m})$ & Rq $(\mu \mathrm{m})$ & Rz $(\mu \mathrm{m})$ & Rt $(\mu \mathrm{m})$ & Rsk \\
\hline METAS & 0.059883 & 0.074573 & 0.327789 & 0.456508 & -0.033 \\
DTU_1 & 0.06 & 0.075 & 0.328 & 0.457 & -0.022 \\
DTU_2 & 0.060 & 0.075 & 0.328 & 0.456 & -0.033 \\
MIKES & 0.0595 & 0.0742 & 0.3276 & 0.4561 & -0.0167 \\
SP & 0.0597 & 0.0744 & 0.3274 & 0.456 & -0.0188 \\
LNE & 0.0598589 & 0.07393566 & 0.32751571 & 0.4563038 & -0.141065 \\
INRIM_1 & 0.0597 & 0.0744 & 0.3274 & 0.4561 & -0.0186 \\
INRIM_2 & 0.0599 & 0.0746 & 0.3278 & 0.4564 & -0.0334 \\
UME & 0.061 & 0.075 & 0.337 & 0.459 & -0.029 \\
NIMT & 0.0599 & 0.074 & 0.3278 & 0.4565 & -0.1641 \\
CEM & 0.059859 & 0.073936 & 0.327516 & 0.456304 & -0.141 \\
NMC/A*STAR & 0.0595 & 0.0742 & 0.3276 & 0.4561 & -0.0186 \\
CMS & 0.059979 & 0.073939 & 0.327796 & 0.455334 & -0.135478 \\
INMETRO & 0.0597 & 0.0744 & 0.3274 & 0.4561 & -0.0186 \\
\hline Mean & 0.05981 & 0.07435 & 0.32766 & 0.45621 & -0.061 \\
StdDev & 0.00017 & 0.00037 & 0.00022 & 0.00038 & 0.059 \\
\hline
\end{tabular}

Table 9. Software used by participating laboratories for evaluating the softgauges.

\begin{tabular}{|l|l|}
\hline Institute & Software \\
\hline METAS & METAS developed LabView software \\
\hline DTU_1 & Home made RCS4G \\
\hline DTU_2 & RoughnessPro by Image Metrology \\
\hline MIKES & Taylor Hobson Ultra, Version $\mathrm{n}^{\circ}: 5.14 .9 .70$ \\
\hline SP & Taylor Hobson Ultra, Version $\mathrm{n}^{\circ}: 4.6 .8$ \\
\hline
\end{tabular}




\begin{tabular}{|l|l|}
\hline LNE & Mountains Premium, Version $\mathrm{n}^{\circ}: 6.2 .6845$ \\
\hline INRIM_1 & Taylor Hobson Ultra V5.1.14 \\
\hline INRIM_2 & RoughnessPro by Image Metrology \\
\hline UME & Mahr Perthometer Concept, Version 6.3 \\
\hline NIMT & home made \\
\hline CEM & Mountains Map, Version $\mathrm{n}^{\circ}: 6.0 .0 .5727$ \\
\hline NMC/A*STAR & Taylor Hobson Ultra, Version $\mathrm{n}^{\circ}: 5.21 .9 .36$ \\
\hline CMS & CMS_Surf.exe, version 2.1.1 \\
\hline INMETRO & Taylor Hobson Ultra, Version $\mathrm{n}^{\circ}: 5.23 .12 .97$ \\
\hline
\end{tabular}

\subsection{Graphical representation of deviations from the mean}
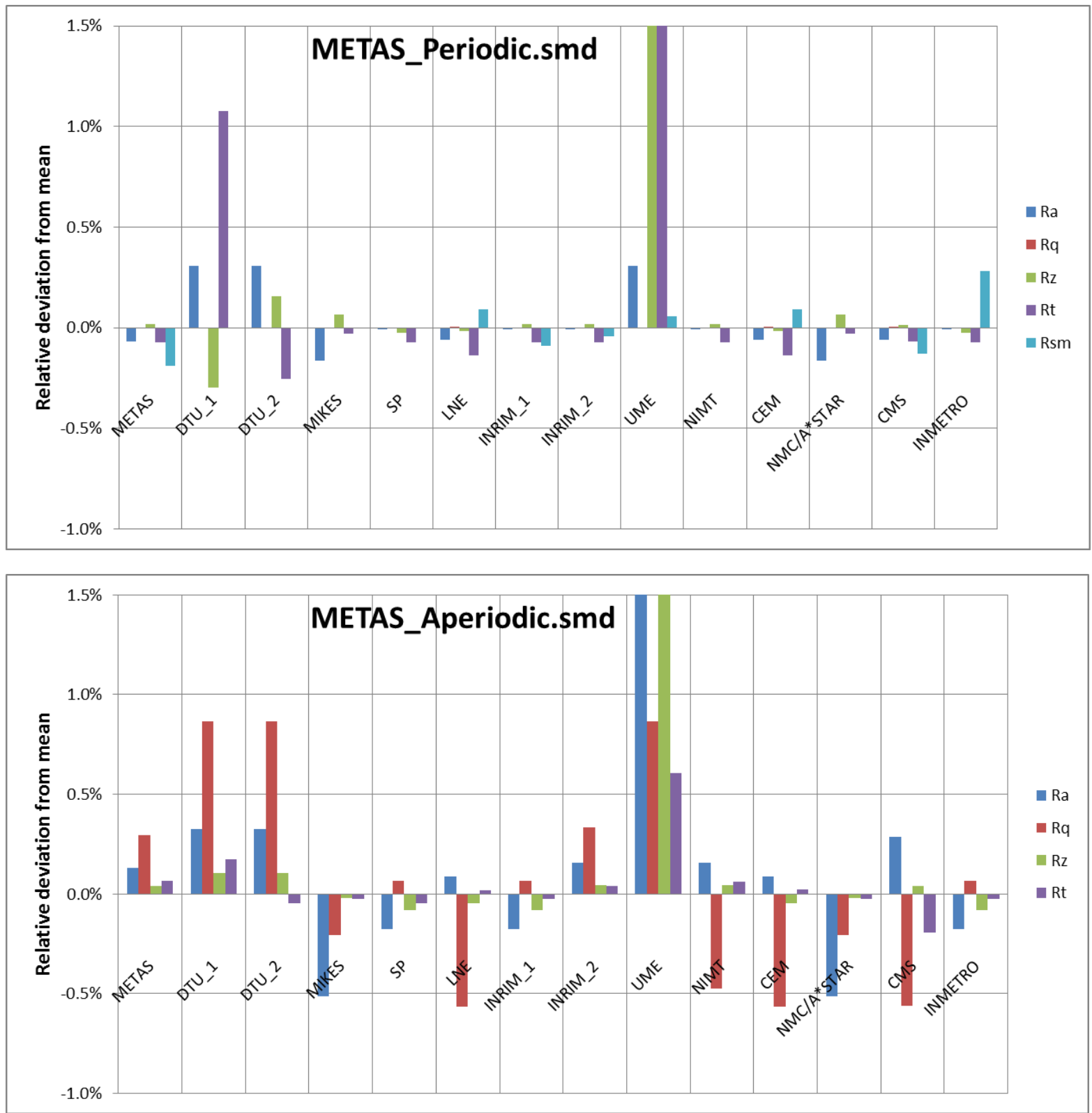

Figure 10. Relative deviation from mean. 

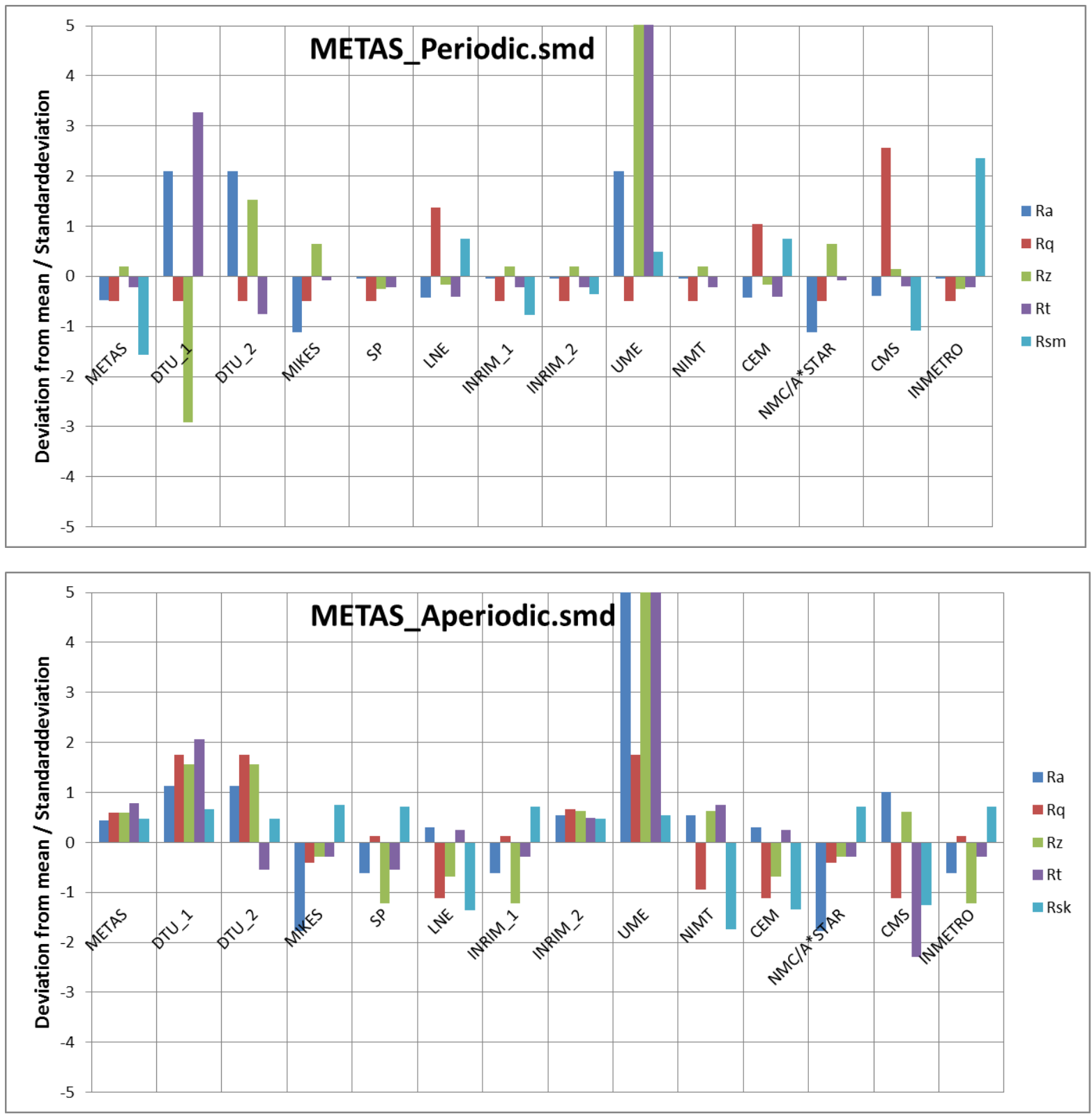

Figure 11. Deviation from mean in terms of multiples of the standard deviation.

\section{Conclusions}

After the first corrective actions and some corrections taken by a few of the participating laboratories, the number of $E_{n}$ values $>1$ could be reduced from 32 to 20 out of a total of 395 individual results, which corresponds to $5 \%$ and can statistically be expected, since the $E_{n}$ criterion is based on a $95 \%$ confidence interval. On good quality standards, such as the Halle A2 depth setting or the Halle D1 fine roughness standards, all results were in good agreement. 13 of the values with $E_{n}>1$ were observed on the Rubert D1 standard, which shows clear signs of use and damage and the largest standard deviations for the peak parameters, i.e. between $5 \%$ and $10 \%$.

Regarding the softgauges, an analysis is much more difficult, since no uncertainties were quoted and reference values are not available (the mean of the reported results cannot be considered to be a reference value). Most of the results agree within roughly $0.2 \%$ of the value. This can hardly be explained by numerical computation accuracy and a more detailed study needs to be carried out, taking into account the results of similar comparisons on other softgauges. 


\section{References}

[1] Calibration of surface roughness standards , http://kcdb.bipm.org/appendixB/KCDB ApB info.asp?cmp idy=986\&cmp cod=EURAMET.L$\underline{\mathrm{K} 8 \& \text { prov}=e x a l e a d}$

[2] ISO 5436-1:2000, Geometrical Product Specifications (GPS) - Surface texture: Profile method; Measurement standards - Part 1: Material measures

[3] ISO 4287:1997, Geometrical Product Specifications (GPS) - Surface texture: Profile method Terms, definitions and surface texture parameters 
12 Appendix: Equipment of the participating laboratories

\begin{tabular}{|c|c|c|c|c|c|}
\hline Institute & Instrument & Stylus & Sampling spacing & Meas. speed & Meas. force \\
\hline METAS & Taylor Hobson Talysurf FTS 120L & $\mathrm{TH}, 2 \mu \mathrm{m}, 90^{\circ}$ & $0.25 \mu \mathrm{m}$ & $0.5 \mathrm{~mm} / \mathrm{s}$ & $0.72 \mathrm{mN}$ \\
\hline DTU-CGM & Taylor Hobson Talysurf 5-120 & $\mathrm{TH}, 2 \mu \mathrm{m}, 70^{\circ}$ & $0.1 \mu \mathrm{m}$ & $0.1 \mathrm{~mm} / \mathrm{s}$ & - \\
\hline MIKES & Taylor Hobson Form Talysurf & $\mathrm{TH}, 2 \mu \mathrm{m}$ & $0.25 \mu \mathrm{m}$ & $0.5 \mathrm{~mm} / \mathrm{s}$ & $1.2 \mathrm{mN}$ \\
\hline IPQ & Mahr Pethometer S8P & Mahr, $2 \mu \mathrm{m}, 90^{\circ}$ & $0.5 \mu \mathrm{m}$ & $0.5 \mathrm{~mm} / \mathrm{s}$ & $0.4 \mathrm{mN}$ \\
\hline BEV & $\begin{array}{l}\text { SIOS NMM-1 with laser focus } \\
\text { sensor (LFS) }\end{array}$ & $\begin{array}{l}\text { SIOS LFS, integrated } \\
\text { with NMM-1 }\end{array}$ & $0.1 \mu \mathrm{m}$ & $2 \mu \mathrm{m} / \mathrm{s}$ & 0 (optical) \\
\hline SP & Taylor Hobson Form Talysurf 120 & $\mathrm{TH}, 2 \mu \mathrm{m}, 90^{\circ}$ & $0.25 \mu \mathrm{m}$ & $0.5 \mathrm{~mm} / \mathrm{s}$ & $<0.70 \mathrm{mN}$ \\
\hline INRIM & $\begin{array}{l}\text { Taylor Hobson Talystep } 1 \\
\text { Taylor Hobson Form Talysurf II }\end{array}$ & $\begin{array}{l}\mathrm{TH}, 2.5 \mu \mathrm{m}, 90^{\circ} \\
\mathrm{TH}, 2 \mu \mathrm{m}, 90^{\circ}\end{array}$ & $\begin{array}{l}0.35 \mu \mathrm{m} \\
0.25 \mu \mathrm{m}\end{array}$ & $\begin{array}{l}25 \mu \mathrm{m} / \mathrm{s} \\
0.5 \mathrm{~mm} / \mathrm{s}\end{array}$ & $\begin{array}{l}40 \ldots 100 \mu \mathrm{m} \\
1 \mathrm{mN}\end{array}$ \\
\hline LNE & $\begin{array}{l}\text { Homemade 3D profilometer with } \\
3 \text { laser interferometers }\end{array}$ & $\mathrm{TH}, 2 \mu \mathrm{m}, 90^{\circ}$ & $0.1 \mu \mathrm{m}$ & & $<1 \mathrm{mN}$ \\
\hline CEM & KLA-Tencor P-6 Stylus Profiler & KLA-Tencor, $2 \mu \mathrm{m}, 60^{\circ}$ & $0.1 \ldots 0.2 \mu \mathrm{m}$ & $20 . .200 \mu \mathrm{m} / \mathrm{s}$ & $0.02 . .0 .1 \mathrm{mN}$ \\
\hline GUM & Taylor Hobson Form Talysurf II & $\mathrm{TH}, 2 \mu \mathrm{m}$ & $0.25 \mu \mathrm{m}$ & $0.5 \mathrm{~mm} / \mathrm{s}$ & $0.7 \mathrm{mN}$ \\
\hline DMDM & Mahr MarSurf UD 120 & Mahr, $2 \mu \mathrm{m}, 60^{\circ}$ & $0.25 \mu \mathrm{m}$ & $0.1 \mathrm{~mm} / \mathrm{s}$ & $0.7 \mathrm{mN}$ \\
\hline UME & Mahr Perthometer Concept & Mahr, $2 \mu \mathrm{m}, 90^{\circ}$ & $0.04 \ldots 0.5 \mu \mathrm{m}$ & $0.1 \ldots 0.5 \mathrm{~mm} / \mathrm{s}$ & $0.7 \mathrm{mN}$ \\
\hline NIMT & Kosaka ET 4000 & Kosaka, $2 \mu \mathrm{m}, 60^{\circ}$ & $0.5 \mu \mathrm{m}$ & $0.05 \mathrm{~mm} / \mathrm{s}$ & $0.4 \mathrm{mN}$ \\
\hline NMC/A*STAR & Taylor Hobson PGI 2540 & $\mathrm{TH}, 2 \mu \mathrm{m}, 60^{\circ}$ & $0.125 \mu \mathrm{m}$ & $0.1 . .0 .25 \mathrm{~mm} / \mathrm{s}$ & $0.75 \mathrm{mN}$ \\
\hline CMS/ITRI & Kosaka ET-4100 SURFCORDER & Kosaka, $2 \mu \mathrm{m}, 60^{\circ}$ & $0.025 \ldots 0.35 \mu \mathrm{m}$ & $0.02 \ldots 0.1 \mathrm{~mm} / \mathrm{s}$ & $0.05 \mathrm{mN}$ \\
\hline NMISA & $\begin{array}{l}\text { Taylor Hobson Form Talysurf PGI } \\
840\end{array}$ & $\mathrm{TH}, 2 \mu \mathrm{m}, 60^{\circ}$ & $0.125 \mu \mathrm{m}$ & $1 \mathrm{~mm} / \mathrm{s}$ & $1 \mathrm{mN}$ \\
\hline INMETRO & Taylor Hobson PGI 830 & $\mathrm{TH}, 2 \mu \mathrm{m}, 90^{\circ}$ & $0.125 \mu \mathrm{m}$ & $0.25 \mathrm{~mm} / \mathrm{s}$ & $1 \mathrm{mN}$ \\
\hline
\end{tabular}


13 Appendix: Traceability of the participating laboratories

\begin{tabular}{|l|l|l|l|l|}
\hline Institute & Vertical measurement traceability & NMI & Transverse measurement traceability & NMI \\
\hline METAS & Reference sphere & METAS & Glass line scale artifact & METAS \\
\hline DTU-CGM & 6 step Halle standard & PTB & reference grid & NPL \\
\hline MIKES & Calibration ball & MIKES & Type C1 Normals, calibrated with metrol. AFM & MIKES \\
\hline IPQ & Surface texture standard type A1 & CEM & Surface texture standard type D & IPQ \\
\hline BEV & Laser interferometer & BEV & Laser interferometer & BEV \\
\hline SP & Gauge blocks & SP & Invar line scale & SP \\
\hline INRIM & $\begin{array}{l}\text { Talystep 1: Precision displacement actuator } \\
\text { Formtalysurf: precision ceramic ball }\end{array}$ & INRIM & stage micrometer and/or gratings & INRIM \\
\hline LNE & Laser interferometer & LNE & Laser interferometer & LNE \\
\hline CEM & $\begin{array}{l}\text { Step height standards, calibrated by laser } \\
\text { interferometer (on the NMM SIOS) }\end{array}$ & CEM & $\begin{array}{l}\text { Line scale and grids, calibrated by } \\
\text { interferometer (on the NMM SIOS) }\end{array}$ & laser \\
\hline GUM & Halle, type A2 & PTB & Roughness standards type A2 & PTB \\
\hline DMDM & Roughness standard & HMI/FSB & Laser interferometer & DMDM \\
\hline UME & Piezo transducer's actuator & UME & $\begin{array}{l}\text { Type C standard PGN-3, calibrated by laser } \\
\text { interferometer }\end{array}$ & UME \\
\hline NIMT & $\begin{array}{l}\text { Type A1 standard calibrated by laser interference } \\
\text { microscope }\end{array}$ & NIMT & $\begin{array}{l}\text { Standard glass scale calibrated by line Scale } \\
\text { interferometer }\end{array}$ & NIMT \\
\hline NMC/A*STAR & Hemisphere & NMC/A*STAR & Hemisphere & NMC/A*STAR \\
\hline CMS/ITRI & Step height standard & CMS/ITRI & Line scale standard & CMS/ITRI \\
\hline NMISA & Reference sphere & NMISA & Reference sphere & NMISA \\
\hline INMETRO & 6 step height Halle & PTB & Line scale standard & INMETRO \\
\hline
\end{tabular}




\section{Appendix: CMCs as declared by the participating laboratories in the CIPM MRA}

CCL service categories related to surface texture:

5.1.1 (groove) depth (step height) standard (e.g. ISO 5436-1 Type A).

5.1.2 tip-condition standard (e.g. ISO 5436-1 Type B).

5.1.3 spacing standard (e.g. ISO 5436-1 Type C).

5.1.4 roughness standard (e.g. ISO 5436-1 Type D).

5.1.5 profile coordinate standard (e.g. ISO 5436-1 Type E).

5.1.6 softgauge standard (reference software data set).

\begin{tabular}{|c|c|c|c|c|c|c|}
\hline \multirow{2}{*}{$\begin{array}{l}\text { NMI } \\
\text { Service Id }\end{array}$} & \multirow{2}{*}{$\begin{array}{l}\text { CCL service } \\
\text { category }\end{array}$} & \multirow[t]{2}{*}{ Parameters } & \multicolumn{2}{|c|}{ Range } & \multirow{2}{*}{$\begin{array}{l}U(k=2) \\
(n m)\end{array}$} & \multirow[t]{2}{*}{ Remarks } \\
\hline & & & Min. & Max. & & \\
\hline METAS\#44 & 5.1 .1 & $d$ & $0.1 \mu \mathrm{m}$ & $1000 \mu \mathrm{m}$ & $\begin{array}{l}\mathrm{Q}[10,0.2 d], \\
d \text { in } \mu \mathrm{m}\end{array}$ & - \\
\hline \multirow[t]{2}{*}{ METAS\#46 } & \multirow[t]{2}{*}{5.1 .3} & $R a, R q$ & $0.01 \mu \mathrm{m}$ & $100 \mu \mathrm{m}$ & $\begin{array}{l}\mathrm{Q}[4,16 R a], \\
R a \text { in } \mu \mathrm{m}\end{array}$ & - \\
\hline & & $R p, R v, R z, R t$ & & & $\begin{array}{l}\mathrm{Q}[30,40 R p], \\
R p \text { in } \mu \mathrm{m}\end{array}$ & - \\
\hline \multirow[t]{2}{*}{ METAS\#47 } & \multirow[t]{2}{*}{5.1 .4} & $R a, R q$ & $0.01 \mu \mathrm{m}$ & $20 \mu \mathrm{m}$ & $\begin{array}{l}\mathrm{Q}[4,30 R a] \\
R a \text { in } \mu \mathrm{m}\end{array}$ & - \\
\hline & & $R p, R v, R z, R t$ & & & $\begin{array}{l}\mathrm{Q}[30,60 R p], \\
R p \text { in } \mu \mathrm{m}\end{array}$ & - \\
\hline DTU/CGM & - & - & - & - & - & - \\
\hline MIKES\#41 & 5.1 .1 & $S$ & $0 \mu \mathrm{m}$ & $400 \mu \mathrm{m}$ & $\begin{array}{l}\mathrm{Q}[10,70 \mathrm{~S}] \\
\mathrm{S} \text { in } \mu \mathrm{m}\end{array}$ & \\
\hline MIKES\#42 & $\begin{array}{l}5.1 .3 \\
5.1 .4 \\
\end{array}$ & $S$ & $0 \mu \mathrm{m}$ & $400 \mu \mathrm{m}$ & $\begin{array}{l}\mathrm{Q}[10,70 \mathrm{~S}], \\
\mathrm{S} \text { in } \mu \mathrm{m}\end{array}$ & \\
\hline \multirow[t]{2}{*}{ IPQ\#101.40 } & \multirow[t]{2}{*}{5.1 .3} & $R a$ & $0.1 \mu \mathrm{m}$ & $10 \mu \mathrm{m}$ & $\begin{array}{l}\mathrm{Q}[50,30 R a], \\
R a \text { in } \mu \mathrm{m}\end{array}$ & - \\
\hline & & $R z, R p, R v, R t$ & & & $\begin{array}{l}\mathrm{Q}[50,30 R z] \\
R z \text { in } \mu \mathrm{m}\end{array}$ & - \\
\hline \multirow[t]{2}{*}{ IPQ\#101.40 } & \multirow[t]{2}{*}{5.1 .4} & $R a$ & $0.1 \mu \mathrm{m}$ & $20 \mu \mathrm{m}$ & $\begin{array}{l}\mathrm{Q}[50,30 R a], \\
R a \text { in } \mu \mathrm{m}\end{array}$ & - \\
\hline & & $R z, R p, R v, R t$ & & & $\begin{array}{l}\mathrm{Q}[50,30 R z], \\
R z \text { in } \mu \mathrm{m}\end{array}$ & - \\
\hline BEV\#25 & 5.1 .1 & $d$ & $0.01 \mu \mathrm{m}$ & $10 \mu \mathrm{m}$ & $\begin{array}{l}\mathrm{Q}[5,10 d] \\
d \text { in } \mu \mathrm{m}\end{array}$ & $\begin{array}{l}\text { different } \\
\text { technique }\end{array}$ \\
\hline SP\#36 & 5.1 .1 & $H$ & $0.05 \mu \mathrm{m}$ & $1000 \mu \mathrm{m}$ & $\begin{array}{l}\mathrm{Q}[5,20 H], \\
H \text { in } \mu \mathrm{m}\end{array}$ & - \\
\hline \multirow[t]{2}{*}{ SP\#37 } & \multirow[t]{2}{*}{5.1 .3} & $R a, R q$ & $0.01 \mu \mathrm{m}$ & $20 \mu \mathrm{m}$ & $\begin{array}{l}\mathrm{Q}[5,20 R a] \\
R a \text { in } \mu \mathrm{m}\end{array}$ & - \\
\hline & & $R z, R t$ & & & $\begin{array}{l}\mathrm{Q}[10,30 R z], \\
R z \text { in } \mu \mathrm{m}\end{array}$ & - \\
\hline
\end{tabular}




\begin{tabular}{|c|c|c|c|c|c|c|}
\hline \multirow{2}{*}{$\begin{array}{l}\text { NMI } \\
\text { Service Id }\end{array}$} & \multirow{2}{*}{$\begin{array}{l}\text { CCL service } \\
\text { category }\end{array}$} & \multirow[t]{2}{*}{ Parameters } & \multicolumn{2}{|c|}{ Range } & \multirow{2}{*}{$\begin{array}{l}U(k=2) \\
(n m)\end{array}$} & \multirow[t]{2}{*}{ Remarks } \\
\hline & & & Min. & Max. & & \\
\hline INRIM\#24 & 5.1 .1 & $d$ & $0.01 \mu \mathrm{m}$ & $15 \mu \mathrm{m}$ & $\begin{array}{l}\text { Q[1, 4.7 d], } \\
d \text { in } \mu \mathrm{m}\end{array}$ & \\
\hline \multirow[t]{3}{*}{ INRIM\#33 } & \multirow[t]{3}{*}{5.1 .3} & $R a$ & $0.1 \mu \mathrm{m}$ & $20 \mu \mathrm{m}$ & $\begin{array}{l}\mathrm{Q}[10,30 R a], \\
R a \text { in } \mu \mathrm{m}\end{array}$ & - \\
\hline & & $R z, R p, R v, R t$ & & & $\begin{array}{l}\mathrm{Q}[20,50 R z], \\
R z \text { in } \mu \mathrm{m}\end{array}$ & - \\
\hline & & $R S m$ & $50 \mu \mathrm{m}$ & $500 \mu \mathrm{m}$ & $0.5 \mu \mathrm{m}$ & \\
\hline \multirow[t]{2}{*}{ INRIM\#34 } & \multirow[t]{2}{*}{5.1 .4} & $R a$ & $0.1 \mu \mathrm{m}$ & $20 \mu \mathrm{m}$ & $\begin{array}{l}\mathrm{Q}[10,30 R a], \\
R a \text { in } \mu \mathrm{m}\end{array}$ & - \\
\hline & & $R z, R p, R v, R t$ & & & $\begin{array}{l}\mathrm{Q}[20,50 R z], \\
R z \text { in } \mu \mathrm{m}\end{array}$ & - \\
\hline LNE & - & - & - & - & - & - \\
\hline CEM\#33b & 5.1 .1 & $H$ & $0.01 \mu \mathrm{m}$ & $15 \mu \mathrm{m}$ & $\begin{array}{l}\mathrm{Q}[2,20 H], \\
H \text { in } \mu \mathrm{m}\end{array}$ & - \\
\hline \multirow[t]{2}{*}{ CEM\#34 } & \multirow[t]{2}{*}{5.1 .4} & $R a$ & $0.01 \mu \mathrm{m}$ & $15 \mu \mathrm{m}$ & $\begin{array}{l}\mathrm{Q}[9,30 R a], \\
R a \text { in } \mu \mathrm{m}\end{array}$ & - \\
\hline & & $R z$ & & & $\begin{array}{l}\mathrm{Q}[14,40 R z], \\
R z \text { in } \mu \mathrm{m}\end{array}$ & - \\
\hline GUM\#26 & 5.1 .1 & $P t, d$ & $0.1 \mu \mathrm{m}$ & $100 \mu \mathrm{m}$ & $\begin{array}{l}\mathrm{Q}[30,0.5 d], \\
d \text { in } \mu \mathrm{m}\end{array}$ & - \\
\hline \multirow[t]{2}{*}{ GUM\#27 } & \multirow[t]{2}{*}{5.1 .3} & $R a, R q$ & $0.05 \mu \mathrm{m}$ & $30 \mu \mathrm{m}$ & $\begin{array}{l}\mathrm{Q}[15,25 R a], \\
R a \text { in } \mu \mathrm{m}\end{array}$ & - \\
\hline & & $R z, R t$ & & & $\begin{array}{l}\mathrm{Q}[40,50 R p], \\
R p \text { in } \mu \mathrm{m}\end{array}$ & - \\
\hline \multirow[t]{2}{*}{ GUM\#28 } & \multirow[t]{2}{*}{5.1 .4} & $R a, R q$ & $0.05 \mu \mathrm{m}$ & $30 \mu \mathrm{m}$ & $\begin{array}{l}\mathrm{Q}[15,30 R a], \\
R a \text { in } \mu \mathrm{m}\end{array}$ & - \\
\hline & & $R z, R t$ & & & $\begin{array}{l}\mathrm{Q}[40,60 R p], \\
R p \text { in } \mu \mathrm{m}\end{array}$ & - \\
\hline DMDM & - & - & - & - & - & - \\
\hline UME\#34 & 5.1 .1 & $d$ & $0.01 \mu \mathrm{m}$ & $750 \mu \mathrm{m}$ & $\begin{array}{l}\mathrm{Q}[18,30 d] \\
d \text { in } \mu \mathrm{m}\end{array}$ & - \\
\hline UME\#35 & 5.1 .3 & $\begin{array}{l}R a, R q, R z, R p \\
R t, R v\end{array}$ & $0.01 \mu \mathrm{m}$ & $20 \mu \mathrm{m}$ & $\begin{array}{l}\mathrm{Q}[10,40 R a], \\
R a \text { in } \mu \mathrm{m}\end{array}$ & - \\
\hline UME\#36 & 5.1 .4 & $\begin{array}{l}R a, R q, R z, R p \\
R t, R v, R p k \\
R v k, M r_{1}, M r_{2}\end{array}$ & $0.01 \mu \mathrm{m}$ & $20 \mu \mathrm{m}$ & $\begin{array}{l}\mathrm{Q}[10,40 R z] \\
R z \text { in } \mu \mathrm{m}\end{array}$ & - \\
\hline $\begin{array}{l}\text { NIMT\#08060- } \\
10501\end{array}$ & 5.1 .1 & $d$ & $25 \mathrm{~nm}$ & $32 \mu \mathrm{m}$ & $\begin{array}{l}\mathrm{Q}[6.6,12 d], \\
d \text { in } \mu \mathrm{m}\end{array}$ & - \\
\hline \multirow[t]{2}{*}{$\begin{array}{l}\text { NIMT\#08060- } \\
10601\end{array}$} & \multirow[t]{2}{*}{$\begin{array}{l}5.1 .3 \\
5.1 .4\end{array}$} & $R a$ & $25 \mathrm{~nm}$ & $32 \mu \mathrm{m}$ & $\begin{array}{l}\mathrm{Q}[10,12 R a], \\
R a \text { in } \mu \mathrm{m}\end{array}$ & - \\
\hline & & $R z$ & & & $\begin{array}{l}\mathrm{Q}[18,17 R z], \\
R z \text { in } \mu \mathrm{m}\end{array}$ & - \\
\hline $\begin{array}{l}\text { NMC/A*STAR } \\
\text { \#D049 }\end{array}$ & 5.1 .4 & $\begin{array}{l}\text { ISO roughness } \\
\text { parameters } \\
(\text { eg. } R a)\end{array}$ & $0.1 \mu \mathrm{m}$ & $10 \mu \mathrm{m}$ & $\begin{array}{l}\mathrm{Q}[36,30 R a], \\
R a \text { in } \mu \mathrm{m}\end{array}$ & - \\
\hline
\end{tabular}




\begin{tabular}{|c|c|c|c|c|c|c|}
\hline \multirow{2}{*}{$\begin{array}{l}\text { NMI } \\
\text { Service Id }\end{array}$} & \multirow{2}{*}{$\begin{array}{l}\text { CCL service } \\
\text { category }\end{array}$} & \multirow[t]{2}{*}{ Parameters } & \multicolumn{2}{|c|}{ Range } & \multirow{2}{*}{$\begin{array}{l}U(k=2) \\
(\mathrm{nm})\end{array}$} & \multirow[t]{2}{*}{ Remarks } \\
\hline & & & Min. & Max. & & \\
\hline CMS\#D21 & 5.1 .1 & $D$ & $0.01 \mu \mathrm{m}$ & $50 \mu \mathrm{m}$ & $\begin{array}{l}\mathrm{Q}[5,3.2 D], \\
D \text { in } \mu \mathrm{m}\end{array}$ & \\
\hline CMS\#D13 & $\begin{array}{l}5.1 .3 \\
5.1 .4\end{array}$ & $R a, R q$ & $0.01 \mu \mathrm{m}$ & $20 \mu \mathrm{m}$ & $\begin{array}{l}\mathrm{Q}[5,13 R], \\
R \text { in } \mu \mathrm{m}\end{array}$ & \\
\hline NMISA\# & 5.1 .1 & $d$ & $0.01 \mu \mathrm{m}$ & $3000 \mu \mathrm{m}$ & $\begin{array}{l}\mathrm{Q}[4,20 d], \\
d \text { in } \mu \mathrm{m}\end{array}$ & \\
\hline NMISA\# & $\begin{array}{l}5.1 .3 \\
5.1 .4\end{array}$ & $R a$ & $0.01 \mu \mathrm{m}$ & $100 \mu \mathrm{m}$ & $\begin{array}{l}\mathrm{Q}[10,30 R a] \\
R a \text { in } \mu \mathrm{m}\end{array}$ & \\
\hline INMETRO\#27 & 5.1 .1 & $H$ & $0.05 \mu \mathrm{m}$ & $20 \mu \mathrm{m}$ & $\begin{array}{l}20+2 H \\
H \text { in } \mu \mathrm{m}\end{array}$ & \\
\hline INMETRO\#29 & $\begin{array}{l}5.1 .3 \\
5.1 .4\end{array}$ & $R a, R z, R \max$ & $0.01 \mu \mathrm{m}$ & $20 \mu \mathrm{m}$ & $\begin{array}{l}10+20 R a \\
R a \text { in } \mu \mathrm{m}\end{array}$ & \\
\hline
\end{tabular}

